\title{
ZESZYTY NAUKOWE
}

Szkoły Głównej Gospodarstwa Wiejskiego

w Warszawie

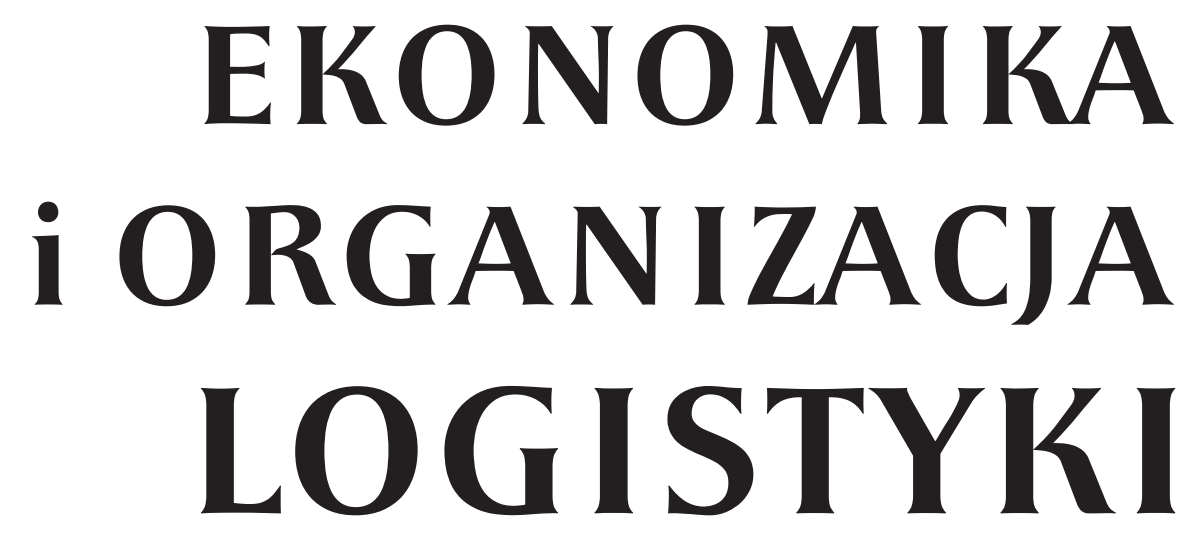

3 (3) 2018

.li

Wydawnictwo SGGW

Warszawa 2018 


\section{RADA NAUKOWA}

Bogdan Klepacki, Szkoła Główna Gospodarstwa Wiejskiego w Warszawie (przewodniczący)

Theodore R. Alter, Pennsylvania State University, USA; Spyros Binioris, Technological Educational Institute of Athens, Grecja; Georgij Cherevko, Lviv State Agrarian University, Ukraina; James W. Dunn, Pennsylvania State University, USA; Wojciech Florkowski, University of Georgia, USA; Elena Horska, Slovak University of Agriculture in Nitra, Słowacja; Marianna Jacyna, Politechnika Warszawska; Qi Jun Jiang, Shanghai Ocean University, Chińska Republika Ludowa; Stanisław Krzyżaniak, Instytut Logistyki i Magazynowania w Poznaniu; Radim Lenort, Technical University of Ostrava, Republika Czeska; Iwo Nowak, redaktor naczelny czasopisma „Logistyka”; Olena Slavkowa, Sumy State University, Ukraina; Bojan Rosi, University of Maribor, Słowenia; Henryk Runowski, Szkoła Główna Gospodarstwa Wiejskiego w Warszawie; Elżbieta J. Szymańska, Szkoła Główna Gospodarstwa Wiejskiego w Warszawie; Maria Tsirintani, Technological Educational Institute of Athens, Grecja

\section{KOMITET REDAKCYJNY}

Elżbieta J. Szymańska (redaktor naczelna)

Aneta Beldycka-Bórawska (redaktor języka angielskiego); Joanna Baran (redaktor tematyczny - magazynowanie); Aleksandra Górecka (redaktor tematyczny - infrastruktura); Konrad Michalski (redaktor tematyczny - systemy logistyczne); Tomasz Rokicki (redaktor tematyczny - transport i spedycja); Hubert Szczepaniuk (redaktor statystyczny); Elżbieta J. Szymańska (redaktor tematyczny - łańcuchy dostaw); Marcin Wysokiński (redaktor tematyczny - materiały niebezpieczne i BHP)

Konrad Michalski (sekretarz)

strona www: eiol.wne.sggw.pl

Projekt okładki - Maria Zych-Lewandowska

Redaktor - Anna Dołomisiewicz

Redaktor techniczny - Violetta Kaska

ISSN 2450-8055 eISSN 2543-8867

Wydawnictwo SGGW

ul. Nowoursynowska 166, 02-787 Warszawa

tel. 225935520 (-22, -25 - sprzedaż)

e-mail: wydawnictwo@sggw.pl

www.wydawnictwosggw.pl

Druk / Printed by: ZAPOL sp.j., al. Piastów 42, 71-062 Szczecin 


\section{Spis treści}

\section{Contents}

\section{Uliana Andrusiv, Anzhela Czerchata}

Improvement of the logistics chain of the enterprise: practical aspects

Poprawa łańcucha logistycznego przedsiębiorstwa: praktyczne aspekty

\section{Aneta Beldycka-Bórawska}

Logistyka w gospodarstwach roślinnych

Logistics in plant farms

\section{Teresa Gadek-Hawlena, Marcelina Los}

Nowoczesne rozwiązania w pojazdach ciężarowych i ich wpływ

na bezpieczeństwo ruchu drogowego

Modern solutions in heavy goods vehicles and their influence on road safety

\section{Aleksandra Górecka, Izabela Waśniowska}

Doskonalenie przepływów w kanale dystrybucji na przykładzie piekarni

Flows improving in the distribution system on the example of a bakery

\section{Bogdan Klepacki, Malgorzata Koper}

Bezpieczeństwo w ruchu drogowym w opiniach jego uczestników

Road safety in the opinion of its participants

\section{Magdalena Nowik}

Big Data jako wsparcie w zarządzaniu łańcuchami dostaw

Big Data as a support in supply chain management

\section{Tomasz Rokicki, Stanislaw Bereziński}

Ocena ryzyka wykorzystania giełd transportowych w działalności

firm przewozowych

Assessment of the risk of using transport exchanges in the activities

of transport companies

\section{Joanna Stankiewicz, Konrad Michalski}

Rozwiązania z zakresu inteligentnych systemów transportowych w wybranych miastach w Polsce

Solutions in the field of intelligent transport systems in selected cities 



\title{
Ekonomika i Organizacja Logistyki \\ 3 (3), 2018, 5-14
}

DOI: 10.22630/EIOL.2018.3.3.17

\author{
Uliana Andrusiv ${ }^{1}$, Anzhela Cherchata ${ }^{2}$ \\ ${ }^{1}$ Ivano-Frankivsk National Technical University of Oil and Gas \\ ${ }^{2}$ Prydniprovska State Academy of the Civil Engineering and Architecture \\ - SHEE
}

\section{Improvement of the logistics chain of the enterprise: practical aspects}

\section{Poprawa lańcucha logistycznego przedsiębiorstwa: praktyczne aspekty}

\begin{abstract}
The article is devoted to application of distributive logistics at an enterprise. For determining peculiarities of functioning of the logistic chain, an analysis of each of its components has been made. On the basis of the obtained results, the necessity of creating a distribution center at an enterprise in the context of improving its logistics chain has been substantiated. As a priority direction for determining the variant of location of a distribution center for an enterprise the method of determining of the weight center has been proposed.
\end{abstract}

Key words: logistics, logistics chain, distribution center

Synopsis. Opracowanie dotyczy zastosowania logistyki dystrybucyjnej w przedsiębiorstwie. W celu określenia specyfiki funkcjonowania łańcucha logistycznego dokonano analizy każdego z jego elementów. Na podstawie uzyskanych wyników potwierdzono konieczność stworzenia centrum dystrybucyjnego w przedsiębiorstwie w celu usprawnienia jego łańcucha logistycznego. Jako priorytetowy kierunek dla określenia wariantu lokalizacji centrum dystrybucyjnego dla przedsiębiorstwa zaproponowano metodę wyznaczania środka ciężkości.

Słowa kluczowe: logistyka, łańcuch logistyczny, centrum dystrybucji

\section{Introduction}

Fundamental to the success of any supply chain is the management of both the material flow of product and the information flow. For any supply chain to be effective, these flows cannot be interrupted or distorted without incurring waste and consuming management time in correcting problems. In addition, the procurement of materials, manufacturing and distribution of products accounts for the majority of the overall cost and is key to customer service and overall competitiveness. Therefore, the development of a supply 
chain management capability for modern businesses is a means of contributing to business efficiency, effectiveness, and competitive advantage over rival producers [Holweg and Rich 2004].

Successful management of material flows at a separate enterprise is possible only in case of allocation of the corresponding function. In connection with the increased competition and increased requirements for the quality of the organization of processes at enterprises, the issues of logistics management are becoming increasingly actual. At the present stage of development of management science, logistics is a means of achieving strategic goals through functional integration and coordination of material flows. This mainly concerns distribution logistics, which covers the whole range of tasks in management of material flows on the way from a producer to a consumer. Efficient distribution allows you to solve a problem of supply, production, marketing in terms of formation of an economically viable reproduction cycle, and consequently, development of an organization by ensuring and maintaining competitive advantages.

The works of such scholars, as: D.J. Bowersox, N.I. Chukhrai, D.J. Closs, Yu.V. Ponomareva, A.V. Tkachova, T.O. Zahorna, M. Wasylko, were devoted to the questions of logistics, use of logistic approaches in which the authors focus on the use of logistics in certain industries.

Thus, Tkachova and Zahorna [2012] stresses on application of the supply chain strategy established on the basis of cooperation of organizations that carry out successive phases of production and logistics processes from raw materials to final products in the forestry complex.

The theory and methodology of formation and development of distributive logistics in the last years was in the sight of such prominent economists, as: B. Anikin, V. Bobkova, N.V. Chornopyska, N.I. Chukhrai, V.K. Gubenko, A. Hadzhynskyy, Ye.V. Krykavsky, V.T. Lozynsky, I. Strutinskaya, I. Fechner and others.

In particular, the functions of distributive logistics have been considered, positive and negative factors that influence management of supply chains have been substantiated by Gubenko [2007]. Lozynsky [2010] analyzes existing approaches to substantiate the feasibility of formation of modern distribution systems of goods. Strutynskaya in her article [2012] considered the analysis of classification of logistic centers in the context of rethinking the requirements and methods of organizing logistics at enterprises. Attention was paid to the functional use of logistics center services.

In spite of the wide field of available research, there is a need to highlight the issues connected with distribution logistics and logistics chain improvement. Therefore, the outlined problematics in the article is very relevant and it needs to be further explored.

\section{Aim and research methods}

The aim of the article is to determine the significance and role of distribution logistics at an enterprise and to improve the logistic chain by forming a distribution center. To achieve the set goal, the following tasks have been defined:

- to consider the essence of distributive logistics; 
- to reveal the peculiarities of functioning of the logistics chain on the example of a certain enterprise;

- to substantiate the introduction of a distribution center at an enterprise as one of the important measures for improvement of the logistics chain.

The theoretical basis of the research have become developments of domestic and foreign scientists on the application of distributive logistics, materials of international and domestic scientific and practical conferences.

The general scientific and special research methods are used in the work. For interpretation of the essence of logistic categories, the methods of theoretical generalization and analysis are applied. The method of determining the center of gravity is used for scientific substantiation of introduction of the distribution center.

This method is based on the calculation of the center of gravity of the distribution center to certain consumers, that is, the distribution center will be located at a certain point - closer to large buyers. To apply this method, it is necessary to map the coordinate axis of the service area and find the coordinates of the points where the consumers of the material flow are located. Coordinates of the center of gravity of freight flows are the points at which the distribution center can be located.

\section{Presentation of the main material of the research}

To date, there are different approaches to the definition of distributive logistics. Kostoglodov and Harysova [1997] define distribution logistics as a process for managing commercial, channel and physical distribution of finished products and services in order to meet consumer demand and profit. Hadzhynskyy [2013] considers distribution logistics as a set of interrelated functions implemented in the process of distributing material flow between different wholesale buyers, that is, in the process of wholesale sales of goods.

However, having defined the object (material flow at the stages of movement from a supplier to a customer) and the subject of distribution logistics (organization of an effective process of product promotion to a consumer), one can draw the following conclusion: the functions of distributive logistics should not be limited by the distribution of material flow. A wider understanding of distribution logistics is presented in the work of Ponomareva [2003] according to which distribution logistics is the management of transportation, warehousing and other material and nonmaterial operations which are carried out in the process of bringing the finished product to a consumer in accordance with the interests and requirements of the latter, as well as transmission, storage and processing of relevant information [Ponomareva 2003]. Otherwise, it is also called marketing or marketing logistics.

However, we agree with the opinion, the difference in distribution logistics from traditional selling and sales lies in subordination of the process of management of material and information flows to the goals and tasks of marketing; systematic interconnection of the process of distribution with production processes and procurement; systemic interconnection of all elements of the logistic chain [Voronkova et al. 2007]. 
The logistic chain is a linearly arranged totality of individual and legal entities (producers, distributors, warehouses of general purpose), which carry out logistics operations for bringing material flow from one logistics system to another or to another consumer, and through which the commodity and information flows from supplier to customer pass [Krykavsky et al. 2006].

For the effective functioning of the logistics chain it is necessary to consider each of its components separately. Each link in the logistics chain includes its elements, which collectively form the material basis of logistics and combine the following elements: vehicles and equipment, warehousing, communication and management facilities, etc.

Let us consider the formation of the practical principles of improvement of the logistics chain on the example of the LC Interplyt Nadvirna Ltd.

The main elements of the logistics chain are the scope of supply, production, distribution, intermediate storage and transportation. To determine the peculiarities of functioning of the logistics chain of the LC Interplyt Nadvirna Ltd., we will examine each component (Fig. 1). The scope of supply covers various suppliers. The suppliers of the first level (wood) are the Bystrytsya, the Zelena, the Prykarpatlis, the Volynsklis logging enterprises. The suppliers of the second level are the Oriana (Kalush) concern, the Zorya (Rubizhne) chemical enterprise. The suppliers of the third level are the Alkor company, which is engaged in manufacture of self-adhesive sticker, which is used for chipboard laminating.

The connecting link between the elements of the chain is transport and warehouse logistics. Transport logistics is a branch of logistics that deals with organization and planning of cargo transportation. Delivery of raw materials is carried out by the Transportlis company and the Ukrzaliznytsya railway company. The Transportlis company supplies timber to the LC Interplyt Nadvirna Ltd. enterprise by automobile timber carriers. The Ukrzaliznytsya railway company supplies timber from the Volynsklis company by special railway goods wagons. Carbamide-formaldehyde resin, ammonium chloride, carbamide and chemicals necessary for the production of chipboard are supplied by the Ukrzaliznytsya railway company using specially designed tanks for this purpose.

The logistic process in the warehouse assumes optimal placement of cargo in a warehouse and rational management of it. The warehouse is a special stationary or mobile space or other place of concentration of material values. The LC Interplyt Nadvirna Ltd. has the following in its disposal: The Nyzhniy warehouse - warehousing and sorting of raw materials by sorts and breeds; chips warehouse; raw chips; dry chips warehouse; The Verkhniy warehouse is the warehouse of finished products.

Industrial logistics investigates management of material flows within an enterprise in relation to production processes involved in production of separate products or semi-finished products. Industrial logistics is based on formation of intraproductive logistic systems at the LC Interplyt Nadvirna Ltd. These systems include: automated processes for supplying wood to production sites; automated process of production of chipboard; automated systems of transportation and storage of material resources at production sites.

The LC Interplyt Nadvirna Ltd. uses a complex of technological, power, transport and other types of equipment, tools and fittings, buildings and structures necessary for the production process. 

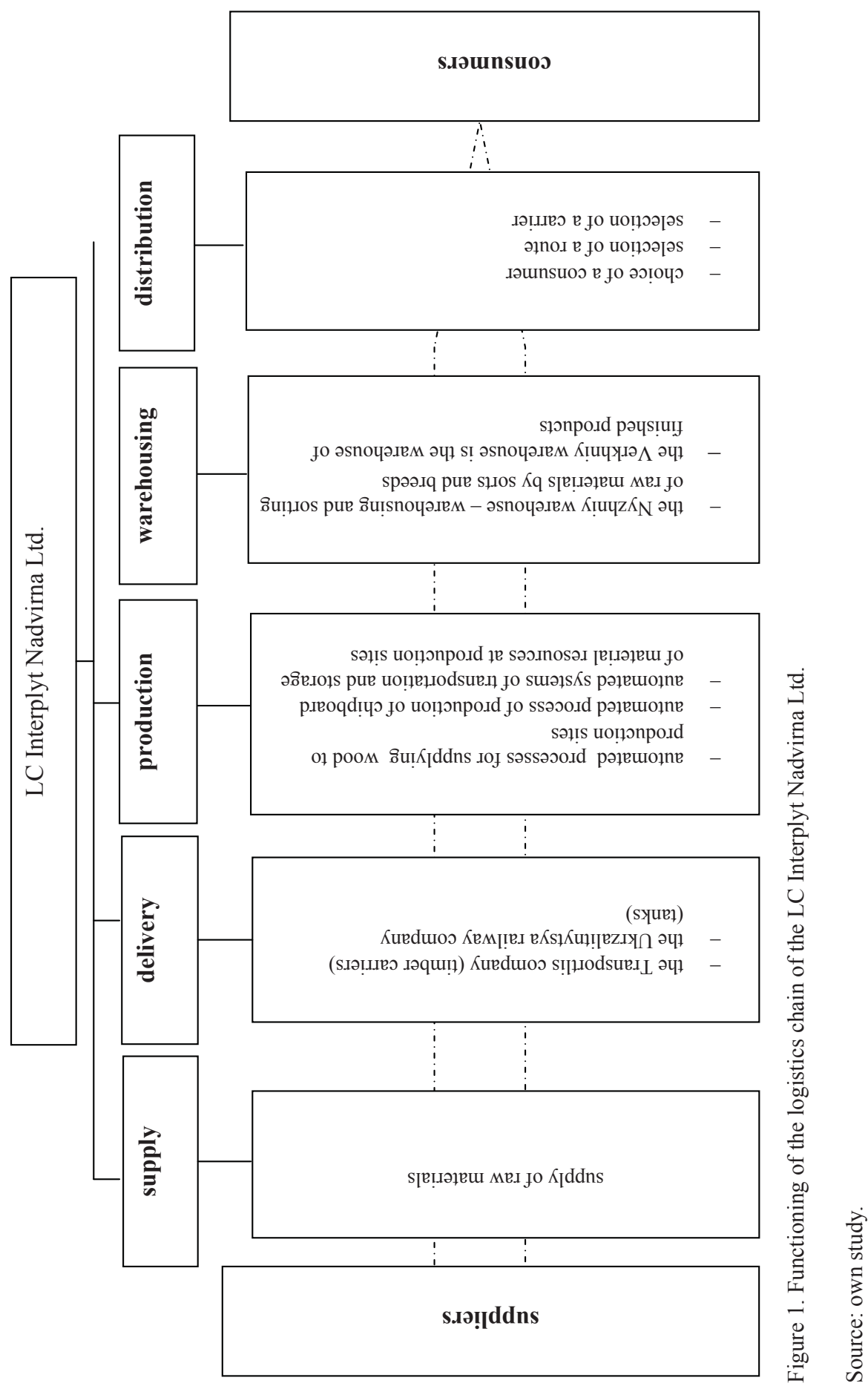
Chipboards are produced from different types of wood, which in most cases comes from the western regions of Ukraine and with the use of carbamide-formaldehyde resins, ammonium chloride, carbamide and chemicals. Chipboard is used for manufacture of furniture, interior decoration inside houses, etc. [Krykavsky 2005].

The task of distribution logistics requires solving of the following issues: choice of a consumer; selection of a route; selection of a carrier. The LC Interplyt Nadvirna Ltd. applies radiant transportation system. This means that the company provides several consumers with a product. The carriers of products which carry out export are the Euro-Trade Ltd., the Ukrzaliznytsya railway company. On the domestic market, the products are supplied by the Transportalis company. The main consumers of the products are (Fig. 2):

1. Export: Poland, Moldova, Hungary, Romania.

2. Domestic market: the Azovstal company, Mariupol, the Kherson shipbuilding company, the Opal plant Rivne, the Vitas Ltd. (Kyiv), the Domeks company (Kharkiv) and others.
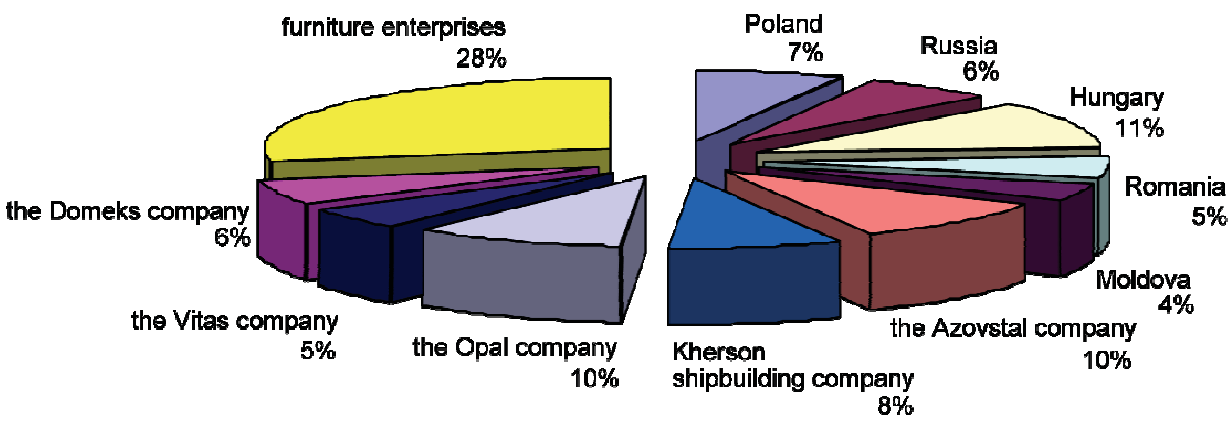

Figure 2. Distribution of annual volumes of work by segments of the market

Source: based on the own study.

Retail network belongs to the second level consumers. It includes a network of construction supermarkets and a network of furniture stores. The network of construction supermarkets includes: the Epicenter; the Bud-service, the Vash dim, the Budmaterialy, the Vse dlya budivnytstva. The furniture stores network: the Mebli dlia domu, the Mebli dlia ofisu, the Mriya, the Kukhnya na vash smak wardrobes. Consumers of the third level are end users. These include firms and households.

One of the conditions for improving the logistics chain is designing of distribution systems based on the choice of the variant of distribution center location.

Distribution center is a wholesale warehouse the task of which is to optimize the sales process in geographically distant markets.

Some scholars believe that the distribution center is a wholesaler whose task is to optimize the sales process in geographically distant markets [Bobkova 2009, Razgulyaev 2011].

However, agreeing with the opinion of other scholars [Gubenko 2007, Holste 2011], we consider that it is not necessary to identify the distribution center only with the 
warehouse, because the main distinctive characteristic of the distribution center's activity, in comparison with a usual warehouse composition, is satisfaction of the needs of consumers.

In this case, Fechner [2010] deserves special attention who considers the logistics center as a distribution center, as a distribution center and he considers that this is a spatial object of the outlined functionality with the corresponding infrastructure and organization of activity through which the logistic services related to acceptance, warehousing, distribution and dispatch of goods, as well as related services which are provided independently concerning a sender or a recipient of economic entities.

For determination of a variant of placing of the distribution center for the LC Interplyt Nadvirna Ltd. we will use the method of determining the center of weight. It is used to determine the location of a single distribution center.

The coordinates of the center of weight of freight flows (X; Y), that is, the point at which the distribution warehouse may be located, is determined by the formulas [Andrusiv 2017]:

$$
\begin{aligned}
& \text { Xwarehouse }=\frac{\sum_{i=1}^{n} B_{i} \times X_{i}}{\sum_{i=1}^{n} B_{i}} \\
& \text { Ywarehouse }=\frac{\sum_{i=1}^{n} B_{i} \times Y_{i}}{\sum_{i=1}^{n} B_{i}}
\end{aligned}
$$

where:

$\mathrm{B}_{\mathrm{i}} \quad$ - cargo turnover of the total consumer;

$\mathrm{X}_{\mathrm{i}}, \mathrm{Y}_{\mathrm{i}}$ - coordinates of the total consumer;

$\mathrm{n}-$ number of consumers.

Table. Cargo turnover and coordinates of large domestic market consumers

\begin{tabular}{|c|c|c|c|}
\hline Consumers & $\mathrm{X}(\mathrm{km})$ & $\mathrm{Y}(\mathrm{km})$ & $\begin{array}{c}\text { Commodity turnover } \\
\text { (thous. packs) }\end{array}$ \\
\hline Azovstal & 1014 & 168 & 11 \\
\hline Kherson & 664 & 265 & 12 \\
\hline Vitas & 448 & 194 & 15 \\
\hline Domeks & 903 & 165 & 9 \\
\hline
\end{tabular}

Source: based on the own study. 


$$
\begin{aligned}
& \mathrm{X}_{\text {warehouse }}=\frac{1,014 \cdot 11+664 \cdot 12+448 \cdot 15+903 \cdot 9}{11+12+15+9}=722.7 \\
& Y_{\text {warehouse }}=\frac{168 \cdot 11+265 \cdot 12+194 \cdot 15+165 \cdot 9}{11+12+15+9}=200.5
\end{aligned}
$$

The distribution center according calculations made should be located in Alexandria. The chipboard and laminated plates go directly by rail transport to the Opal plant Rivne).

Logistics of supply at the enterprise should work on: research of demand; forecasting of changes in demand; search for other supply channels.

The reserves for improving production of logistics for the woodworking industry are [Andrusiv and Cherchata 2018]:

1. The increase of the working time of the active part of fixed assets. This can be achieved by: liquidation of unscheduled and intershift downtime; the reduction to a minimum of maintenance of equipment in repair based on improvement of organization of repairs and equipment operation; the increase in the inter-repair period of operation of equipment through its efficient service; the putting into operation of uninstalled equipment and the increase in the share of operating equipment in the total of all available.

2. Optimal loading of equipment. If the increase of the extensive load has an objective limit in the form of calendar time, then the opportunities for growth of intensive use of equipment are practically unlimited. The main ways to increase the intensive use of equipment at an enterprise are: elimination of bottlenecks; high-speed methods of work; more complete supply of raw materials, resources and necessary materials; application of optimal modes of work of equipment; rational use of production space.

3. In distribution logistics it is necessary: to allocate funds on pre- and after-sales service; expand sales channels; to encourage consumers to buy a plate of this particular company.

4. It is necessary to improve the information logistics system at an enterprise. The following is necessary for doing it: organization of communications with clients for achieving the desired level of logistics service; coordination of logistics activities in time and space in order to optimize the work of subsystems of the logistic chain; control over fulfillment of orders and organization of monitoring for moving of chipboard and laminated plate.

\section{Conclusions}

Decisions related to supply chain management and logistics are important for any enterprise, since they can affect business efficiency and increase competitiveness of enterprises.

It is obvious that the theoretical and methodological substantiation of the use of distributive logistics in the practical activity of an enterprise is not complete in the work, and the problem is far from ambiguous, but its ignoring leads to an overestimation of insurance reserves, and, accordingly to the cost of their maintenance. 
Thus, the process of applying distribution logistics is converted into a tool for coordination of interaction of both functional areas (production, marketing, finance), and improvement of the logistics chain. Concentration of attention on the formation of the distribution center contributes to a significant increase in the efficiency of a company, which determines the development of organization and is a factor in shaping the company's success in the market.

In their activities, distribution centers have more opportunities than conventional warehouses. The peculiarity of the work of the modern distribution center is the orientation towards satisfying the needs of consumers, which manifests itself in providing them with a wider range of additional services.

Consequently, we can conclude that the creation of distribution centers to date is one of the most effective ways to improve the system of distribution logistics at enterprises.

\section{References}

Andrusiv U., 2017: Rozpodil'chyy tsentr yak umova vdoskonalennya lohistychnoho lantsyuha $\mathrm{v}$ antykryzovomu upravlinni pidpryyemst [Distribution center as a condition for improvement of the logistics chain in the crisis management of the enterprise], Priazovsky Economic Herald 1 (01), 38-42.

Andrusiv U., Cherchata A., 2018: Innovative Aspects of Logistics Systems Development in the Region "Modern Management Technologies in the Transformation of Socio-Economic Relations", [in:] Materials of the All-Ukrainian Scientific and Practical Conference, Ivano-Frankivsk.

Bobkova V.M., 2011: Lohistyka dystrybutsiyi [Distribution logistics], SPbGIEU, St. Petersburg.

Fechner I., 2010: Centra logistyczne i ich rola w procesach przepływu w systemie logistycznym

Polski, Prace Naukowe Politechniki Warszawskiej. Transport 76, 19-32, [electronic source] https://www.wt.pw.edu.pl/index.php/content/download/540/2848/file/fechner. pdf [access: 25.09.2018].

Gubenko V.K., 2007: Lohistychna tsentralizatsiya material'nykh potokiv: teoriya i metodolohiya lohistychnykh raspredelytel'nykh tsentrov [Logistical centralization of material flows: theory and methodology of logistics distribution centers], IEP, Donetsk.

Hadzhynskyy A.M., 2013: Lohystyka [Logistics], Dashkov \& K, Moscow.

Holste C., 2009: Logistics News: Warehouse or Distribution Center: What Is It - Really?, Supply Chain Digest Home [electronic source] http://www.scdigest.com/assets/Experts/ Holste_ 09-12-16.php [access: 05.09.2018].

Holweg M., Rich N., 2004: Managing the Flow of Materials Across the Supply Chain, [in:] The Internet Encyclopedia, H. Bidgoli (Ed.), doi: 10.1002/047148296X.tie113 [electronic source] https://onlinelibrary.wiley.com/doi/abs/10.1002/047148296X.tie113 [access: 15.09.2018].

Kostoglodov D., Harysova L., 1997: Raspredelytel'naya lohystyka [Distributive logistics], Expert Bureau, Moscow.

Krikavsky Ye.V., 2005: Lohistychne upravlinnya [Logistic management], Lviv Polytechnic, National University Publishing House, Lviv.

Krykavsky Ye.V., Chukhrai N.I., Chornopyska N.V., 2006: Lohistyka: kompendium i praktykum [Logistics: compendium and workshop], Kondor, Kyiv. 
Lozynsky V.T., 2010: Formation of modern distribution systems of goods: problems of theory and practice, Logistics, the collection of scientific papers, Publishing House of Lviv Polytechnics, Lviv.

Ponomareva Yu.V., 2003: Lohistyka [Logistics], TsNL, Kyiv.

Razgulyaev V.Yu., 2011: RC kak ynstrument optymyzacyy [RC as an optimization tool], Distribution and Logistics 1 (78), 18-21.

Strutinskaya I., 2012: Klasyfikatsiyni oznaky v diyal'nosti lohistychnykhtsentriv [Classification signs in the activity of logistic centers], Scientific Journal Socio-Economic Problems and the State 2 (7), 299-307 [electronic source] http://sepd.tntu.edu.ua/images/stories/ pdf/2012/12sivdlc.pdf [access: 05.09.2018].

Tkachova A.V., Zahorna, T.O., 2012: Management of the logistics activities of industrial enterprises, Noulij, Donetsk.

Voronkova A.E., Kozachenko A.V., Ramazanov S.K., Khlapenov L.E., 2007: Suchasni tekhnolohiyi upravlinnya promyslovym pidpryyemstvom [Modern technologies of industrial enterprise management], Libra, Kyiv.

Corresponding address:

PhD in Economics, Associate Professor Uliana Andrusiv

(https://orcid.org/0000-0003-1793-0936)

Ivano-Frankivsk National Technical University of Oil and Gas

Department of Theory of Economics and Management

Carpathian str., 15

Ivano-Frankivsk-76018, Ukraina tel. (+38) 0677246694

e-mail: andrusivu@ukr.net

PhD in Economics, Associate Professor Anzhela Cherchata (https://orcid.org/0000-0002-6753-2891)

Prydniprovska State Academy of the Civil Engineering and Architecture - SHEE

Department of Management, Project Management and Logistics

Chernyshevs'kogo str., 24a

Dnipro-49600, Ukraine tel. $(+38) 0666101067$

e-mail: acherchataya@gmail.com 


\title{
Ekonomika i Organizacja Logistyki \\ 3 (3), 2018, 15-23
}

DOI: 10.22630/EIOL.2018.3.3.18

\author{
Aneta Beldycka-Bórawska \\ Uniwersytet Warmińsko-Mazurski w Olsztynie
}

\section{Logistyka w gospodarstwach roślinnych Logistics in plant farms}

\begin{abstract}
Synopsis. W artykule przedstawiono działania logistyczne w gospodarstwach roślinnych. Główną uwagę skupiono na logistyce zaopatrzenia, produkcji i dystrybucji. Rolników poproszono o wskazanie głównych dostawców środków do produkcji rolnej oraz odbiorców płodów rolnych. Badania przeprowadzono na grupie 120 gospodarstw roślinnych na terenie województw warmińsko-mazurskiego (75) i pomorskiego (45). W badaniach wykorzystano kwestionariusz ankiety. Zakres czasowy badań obejmował 2017 rok. Z badań wynika, że średnia powierzchnia użytków rolnych w gospodarstwie wynosiła 91,5 ha, wartość maszyn i urządzeń stanowiła ponad 450 tys. zł, a wartość budynków gospodarczych ponad 580 tys. zł. Właściciele badanych gospodarstw współpracowali często z więcej niż jednym dostawcą środków do produkcji rolnej i z kilkoma odbiorcami. Taka sytuacja była dla nich bardzo korzystna, ponieważ gwarantowała im bezpieczeństwo dostaw środków do produkcji rolnej i odbioru płodów rolnych.
\end{abstract}

Słowa kluczowe: logistyka, gospodarstwa roślinne, odbiorcy, dostawcy

\begin{abstract}
The article presents logistic activities in plant farms. The main focus has been paid on supply, production and distribution logistics. In addition, farmers were asked to indicate the main suppliers of agricultural inputs and recipients of agricultural produce. The research was carried out on a group of 120 plant farms in the Warmińsko-Mazurskie Voivodship (75) and the Pomorskie Voivodships (45). The research was conducted using a tool that was a targeted questionnaire. The time range of the research covered the year 2017. The research shows, that the average area of the farm was 91.5 ha farmland and the value of machinery and equipment was over 450,000 PLN and the value of economic buildings over 580,000 PLN. The owners of the surveyed farms often cooperated with more than one supplier of agricultural inputs and several recipients. Such a situation was very beneficial for farmers because it guaranteed their security of supply of means of agricultural production and receipt of agricultural produce.
\end{abstract}

Key words: logistics, plant farms, recipients, suppliers 


\section{Wstęp}

Działalność gospodarstw rolniczych wymaga pozyskania niezbędnych surowców oraz zbytu produktów rolnych. Składa się na nią logistyka zaopatrzenia, produkcji oraz dystrybucji. Sprawne dostawy środków ochrony roślin i nawozów do gospodarstw oraz odbiór produktów z gospodarstw wpływają na ich funkcjonowanie. Z kolei powiązania między ogniwami łańcucha dostaw należą do ważnych czynników kształtujących organizację rynku. Zdaniem Jarzębowskiego [2014] o rozwoju gospodarstw roślinnych decyduje integracja pionowa i pozioma. Głównymi determinantami przewagi konkurencyjnej na rynku są logistyka i transport [Turner 1993].

Rozwój logistyki zależy od wprowadzonych innowacji, które mają charakter zmian procesowych, marketingowych i organizacyjnych. Najczęściej innowacje obejmują wprowadzenie nowych rozwiązań dostaw (oprogramowania, urządzenia oraz techniki służące rozmieszczeniu środków finalnych), zmian w dystrybucji produktów oraz wdrażanie nowych metod organizacji łańcucha dostaw [Juchniewicz 2015].

Logistyka cieszy się dużym zainteresowaniem w przedsiębiorstwach handlowych, usługowych czy międzynarodowych. Szczególnie ważna jest ona w sektorze agrobiznesu, ponieważ odpowiada za zaopatrzenie i dystrybucję oraz jakość produktów rolnych, co przyczynia się do właściwej gospodarki zapasami [Baran i in. 2011]. Przedsiębiorstwa agrobiznesu są również zainteresowane logistyką ze względu na konieczność współpracy i handlu na rynku europejskim [Klepacki 2016].

W literaturze przedmiotu często określa się logistykę jako organizację łańcucha dostaw [Rutkowski 2004]. Czynnikiem utrudniającym rozwój łańcucha dostaw w rolnictwie jest rozdrobnienie struktury produkcji. Producenci o małej skali produkcji nie są w stanie dostarczyć dużych jednolitych partii materiału. Ponadto sprawne funkcjonowanie łańcucha dostaw ogranicza brak kontraktacji niektórych surowców, np. zbóż [Stańko 2007]. Ważnym elementem łańcucha dostaw w rolnictwie są dystrybutorzy, którzy spełniają funkcję „,bufora” chroniącego producentów przed zmianami popytu na wyroby. Są oni odpowiedzialni za dostarczanie produktów tam, gdzie ich potrzebują klienci [Kot i in. 2009].

\section{Cel i metoda badań}

Celem badań była ocena logistyki zaopatrzenia i dystrybucji w gospodarstwach roślinnych. W ramach celu głównego przyjęto następujące cele szczegółowe w zakresie analizowanych gospodarstw:

- poznanie najważniejszych dostawców środków ochrony roślin i nawozów,

- rozpoznanie głównych odbiorców produktów rolnych,

- ocena ważności źródeł informacji o środkach ochrony roślin i nawozach,

- rozpoznanie kanałów sprzedaży produktów rolnych.

W badaniach zastosowano celowy dobór gospodarstw rolnych. Podstawowym kryterium było prowadzenie produkcji roślinnej oraz wyrażenie przez rolników zgody na udział w badaniach. Badania przeprowadzono w 2017 roku. W ich realizacji pomogli pracownicy ośrodków doradztwa rolniczego, którzy dokonali wyboru gospodarstw. Ba- 
dania przeprowadzono w 120 gospodarstwach roślinnych na terenie województw warmińsko-mazurskiego (75) oraz pomorskiego (45). Analizowane gospodarstwa zajmowały się produkcją roślinną (zboża, rzepak, kukurydza, trawy). Badania pozwoliły na wskazanie głównych dostawców środków ochrony roślin i nawozów oraz odbiorców produktów rolnych. Wyniki badań przedstawiono w formie tabelarycznej, graficznej i opisowej.

\section{Wyniki badań}

Objęte badaniami gospodarstwa posiadały dużą powierzchnię użytków rolnych, co było związane z charakterem produkcji roślinnej, która stanowiła duży udział w strukturze produkcji. Średnia powierzchnia użytków rolnych w gospodarstwie wynosiła 91,5 ha i była blisko sześciokrotnie większa od średniej powierzchni gospodarstw w kraju (tab. 1).

Tabela 1. Charakterystyka badanych gospodarstw

Table 1. Characteristics of surveyed farms

\begin{tabular}{|c|c|}
\hline Wyszczególnienie & Wielkość \\
\hline Powierzchnia użytków rolnych (ha) & 91,5 \\
\hline Wartość budynków gospodarczych (zł) & 582102,4 \\
\hline Wartość maszyn i urządzeń (zł), & 456314,4 \\
w tym ciągników (zł) & 113058,3 \\
\hline Liczba zatrudnionych osób (pełnozatrudnieni) & 2,75 \\
\hline
\end{tabular}

Źródło: badania własne.

Rodzaj i skala wyposażenie badanych gospodarstw również wynikała z typu produkcji roślinnej, dlatego cechowała je duża wartość maszyn i urządzeń, w tym ciągników. Przeciętnie w gospodarstwie pracowało 2,75 osób. Środki trwałe oraz zasoby (praca, kapitał oraz ziemia) mają ścisły związek z logistyką, ponieważ umożliwiają przygotowanie produktów rolniczych przeznaczonych do transportu z gospodarstwa.

W gospodarstwach roślinnych istotną rolę odgrywa zużycie chemicznych środków ochrony roślin oraz nawozów mineralnych. Środki te wpływają na wielkość plonów roślin i oddziałują na opłacalność produkcji. W miarę intensyfikacji produkcji zużycie środków chemicznych zwiększa się. Handel środkami ochrony roślin i nawozami odbywa się drogą tradycyjną i poprzez Internet. Rolnicy dzięki Internetowi mogą zapoznać się $\mathrm{z}$ ofertą marketingową przedsiębiorstwa oraz z opiniami innych rolników, co pomaga im w lepszym rozeznaniu rynku. Dysponując pełną informacją, mogą oni zamówić potrzebne środki do produkcji (rys. 1). Z badań wynika, że rolnicy coraz częściej korzystają $\mathrm{z}$ tej formy. W analizowanej grupie znaczna część respondentów określiła rolę Internetu jako bardzo ważną (40,8\%) i ważną (42,5\%), co uzasadnia rozwój handlu elektronicznego. Tylko 13,3\% respondentów wskazało jako średnio ważne korzystanie z handlu elektronicznego, a 2,5\% nie odpowiedziało na to pytanie. 


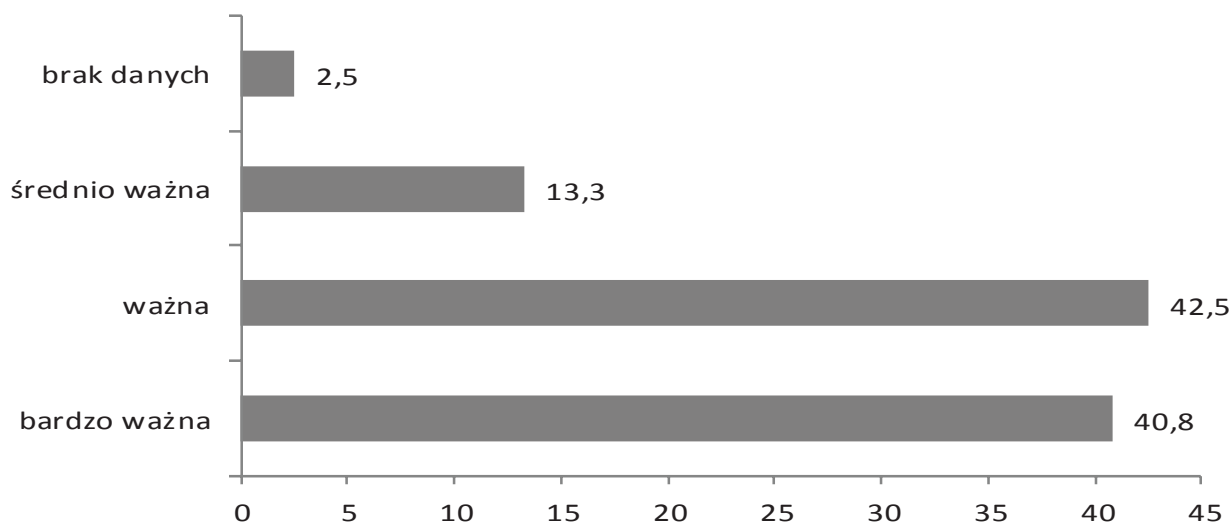

Rysunek 1. Rola Internetu w usprawnieniu zaopatrzenia w środki do produkcji rolnej (\%)

Figure 1. The role of the Internet in improving the supply of materials for agricultural production $(\%)$

Źródło: badania własne.

W łańcuchach dostaw produktów roślinnych istotne znaczenie ma współpraca między rolnikami a dostawcami środków do produkcji. Ścisła współpraca na tym rynku, oparta na partnerskich więziach, pozwala na szybkie diagnozowanie zmieniających się potrzeb i oczekiwań rolników. Z badań wynika, że 6,6\% współpracowało z więcej niż jednym dostawcą, co zapewniało większe bezpieczeństwo dostaw środków ochrony roślin i nawozów (rys. 2). Aż 51,3\% właścicieli gospodarstw współpracowało tylko z jednym dostawcą, co mogło być zagrożeniem w przypadku niewywiązywania się z umowy kontrahenta. Wiodącym dostawcą środków ochrony roślin i nawozów w analizowanych gospodarstwach jest przedsiębiorstwo Agrolok (16,9\%). Wybór tego przedsiębiorstwa wynikał z wysokiej jakości jej produktów.

O dostępności produktów na rynku decydują kanały dystrybucji. Długie kanały dystrybucji powodują wzrost ceny, jaką konsument płaci za produkt finalny. Współcześni konsumenci są bardzo „wrażliwi” na wysoką cenę produktów, dlatego rolnicy dążą do eliminacji pośredników handlowych [Bełdycka-Bórawska i Szymańska 2016]. Przeprowadzone badania umożliwiły rozpoznanie głównych odbiorców produktów rolnych z gospodarstw. Z badań wynika, że 8,5\% właścicieli gospodarstw współpracowało z więcej niż z jednym odbiorcą (rys. 3). Taka sytuacja była korzystna, ponieważ zapewniała bezpieczeństwo odbioru produktów. Jednak $90 \%$ rolników współpracowało z jednym odbiorcą, co nie gwarantowało bezpieczeństwa sprzedaży produktu. Największymi odbiorcami produktów rolnych z analizowanych gospodarstw były dwa przedsiębiorstwa: Golpasz oraz Ampol-Merol. Największa liczba wskazań tych przedsiębiorstw świadczy o ich ugruntowanej pozycji na rynku i popularności oraz wiarygodności wśród rolników.

$\mathrm{W}$ celu sprzedaży produktów rolnicy korzystają $\mathrm{z}$ różnych kanałów dystrybucji (rys. 4). Z badań wynika, że 45,8\% badanych sprzedaje swoje produkty pośrednikom, $45 \%$ bezpośrednio do przetwórstwa, a 38,3\% bezpośrednio w gospodarstwie. Podmioty te współpracują z odbiorcami. Pomimo że sprzedaż pośrednikom stanowi największy odsetek, to wykorzystanie tej formy na rynku systematycznie zmniejsza się, gdyż właściciele 
inne (1 odbiorca)

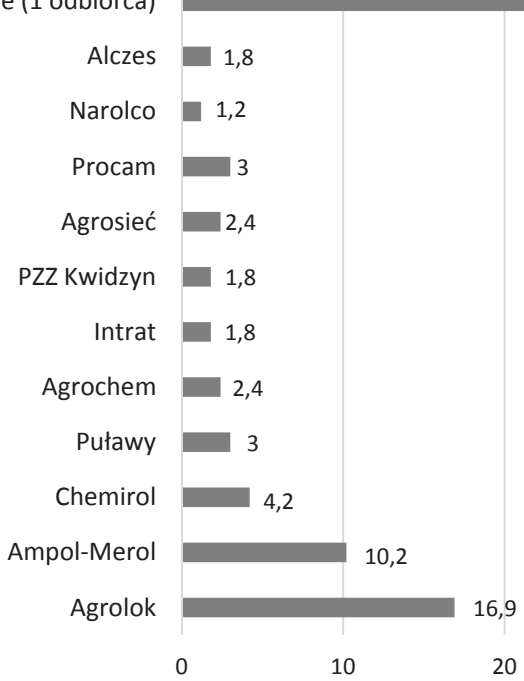

Respondenci mogli wskazać więcej niż jedną odpowiedź.

Rysunek 2. Główni dostawcy środków ochrony roślin i nawozów (\%)

Figure 2. Main suppliers of plant protection products and fertilisers (\%)

Źródło: badania własne.

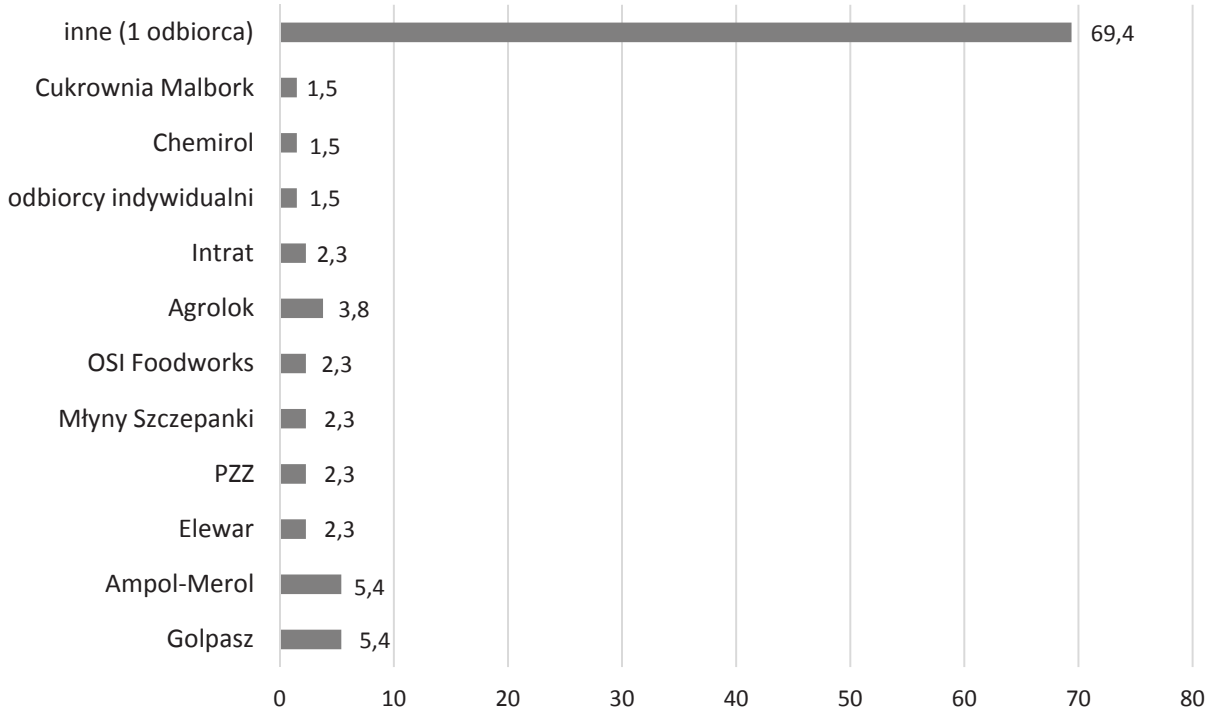

Respondenci mogli wskazać więcej niż jedną odpowiedź.

Rysunek 3. Główni odbiorcy produktów rolnych z gospodarstwa (\%)

Figure 3. The main recipient of agricultural products from the farm (\%)

Źródło: badania własne. 


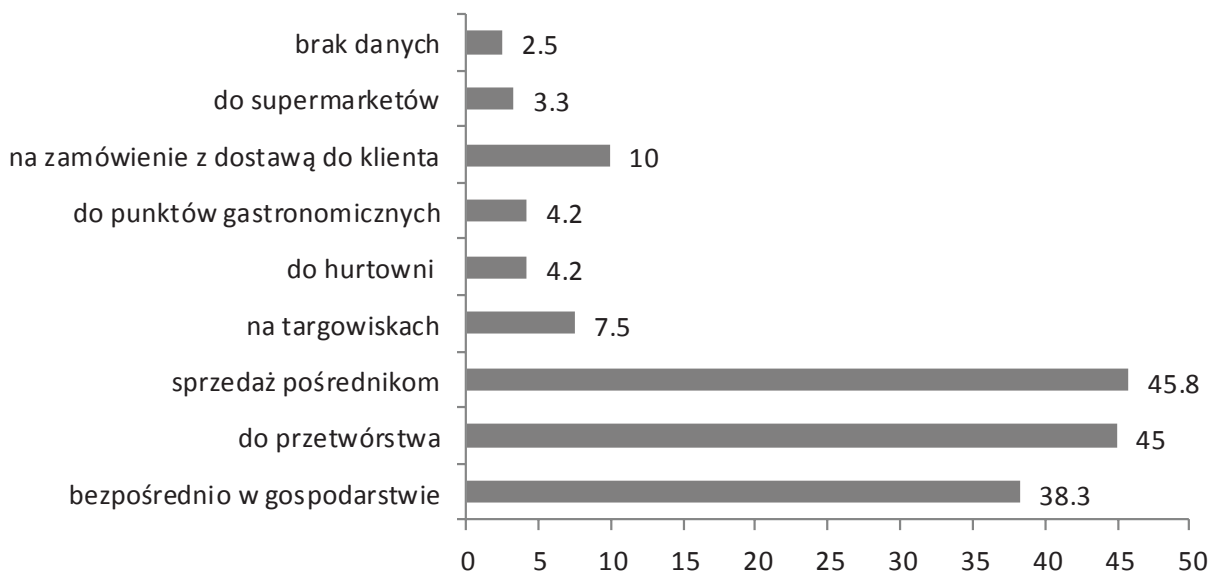

Rysunek 4. Kanały sprzedaży produktów w gospodarstwach (\%)

Figure 4. Channels for the sale of the products in the holdings (\%)

Źródło: opracowania na podstawie badań własnych.

gospodarstw roślinnych są zainteresowani sprzedażą do przetwórstwa, co gwarantuje im wyższe ceny. $\mathrm{W}$ dalszej kolejności pod względem liczby wskazań respondenci wymienili sprzedaż na zamówienie z dostawą do klienta (10\%).

Właściwe zakupy uzależnione są od posiadania i wykorzystania informacji w działalności gospodarczej. Informacja jest długookresowym czynnikiem wzrostu gospodarczego, a w krótkim czasie stanowi warunek determinujący możliwości wykorzystania innych czynników wytwórczych. Rolnicy poszukują informacji na temat środków ochrony roślin i nawozów, korzystając z różnych źródeł (tab. 2). Z badań wynika, że bardzo ważnym źródłem informacji dla rolników są firmy doradcze (26,7\%), czasopisma i publikacje oraz klienci (po 20,8\%), a także wewnętrzne informacje firmy (18,3\%). Za ważne źródła informacji o środkach do produkcji rolnicy uznali dostawców $(45,8 \%)$, wewnętrzne informacje firmy $(42,5 \%)$, odbiorców $(41,7 \%)$ oraz klientów $(39,2 \%)$. Za nieważne $8,3 \%$ ankietowanych uznało wewnętrzne informacje firmy oraz od innych przedsiębiorstw.

Przedsiębiorstwa handlujące nawozami i środkami ochrony roślin coraz częściej stosują różnego rodzaju zachęty w celu zwiększenia sprzedaży. Z informacji zawartych w tabeli 3 wynika, że kluczowymi działaniami wspierającymi zakup środków ochrony roślin i nawozów są wyjazdy szkoleniowe $(20,0 \%)$, bony towarowe $(9,1 \%)$ oraz wartościowe gadżety $(6,7 \%)$. Za ważne czynniki rolnicy uznali wyjazdy szkoleniowe (34,2\%) oraz bony towarowe $(20,8 \%)$. Na promocje wskazał niewielki odsetek respondentów we wszystkich grupach. Wielu rolników nie dokonało jednak oceny tych narzędzi, co może sugerować brak ich wykorzystania w zakresie zakupu środków ochrony roślin oraz nawozów.

Respondenci zostali także poproszeni o wskazanie, czy mają problemy ze sprzedażą produktów rolnych (rys. 5). Z badań wynika, że $63,3 \%$ rolników na ogół nie ma trudności ze sprzedażą, a 1,7\% wskazało na ich brak. Są to gospodarstwa, których właściciele nawiązują współpracę z odbiorcami, gwarantując im dostawę oczekiwanych produktów. 
Tabela 2. Ocena ważności źródeł informacji o środkach ochrony roślin i nawozach (\%)

Table 2. Assessment of validity of sources of information about plant protection products and fertilizers $(\%)$

\begin{tabular}{|c|c|c|c|c|c|}
\hline \multirow[b]{2}{*}{ Wyszczególnienie } & \multicolumn{5}{|c|}{ Ocena ważności źródeł informacji } \\
\hline & $\begin{array}{l}\text { bardzo } \\
\text { ważne }\end{array}$ & ważne & $\begin{array}{l}\text { średnio } \\
\text { ważne }\end{array}$ & mało ważne & nieważne \\
\hline Wewnętrzne informacje firmy & 18,3 & 42,5 & 19,2 & 0,0 & 8,3 \\
\hline Informacje od innych firm & 9,1 & 26,7 & 35,8 & 7,5 & 8,3 \\
\hline Klienci & 20,8 & 39,2 & 15,0 & 2,5 & 0,0 \\
\hline Dostawcy & 13,3 & 45,8 & 15,8 & 2,5 & 1,7 \\
\hline Odbiorcy & 14,2 & 41,7 & 13,3 & 2,5 & 1,7 \\
\hline Kontrahenci & 5,0 & 37,5 & 25,0 & 3,3 & 3,3 \\
\hline Firmy doradcze & 26,7 & 34,2 & 14,2 & 3,3 & 2,5 \\
\hline Placówki naukowe & 15,8 & 27,5 & 22,5 & 6,7 & 3,3 \\
\hline Czasopisma, publikacje & 20,8 & 31,7 & 24,2 & 5,8 & 1,6 \\
\hline Inne & 0,0 & 0,0 & 0,0 & 34,1 & 0,0 \\
\hline Poradnik & 0,8 & 0,0 & 0,0 & 0,0 & 0,0 \\
\hline Brak danych & 41,7 & 0,0 & 35,0 & 77,5 & 90,8 \\
\hline
\end{tabular}

Źródło: badania własne.

Tabela 3. Ocena ważności narzędzi wspierających zakup środków ochrony roślin i nawozów (\%) Table 3. The severity rating tools to purchase plant protection products and fertilizers (\%)

\begin{tabular}{|l|c|c|c|c|c|}
\hline \multirow{2}{*}{ Wyszczególnienie } & \multicolumn{5}{|c|}{ Ocena narzędzi wspierających zakup } \\
\cline { 2 - 6 } & $\begin{array}{c}\text { bardzo } \\
\text { ważne }\end{array}$ & ważne & $\begin{array}{c}\text { średnio } \\
\text { ważne }\end{array}$ & mało ważne & nieważne \\
\hline Wyjazdy szkoleniowe & 20,0 & 34,2 & 20,8 & 2,5 & 0,0 \\
\hline Vouchery turystyczne & 5,0 & 5,8 & 35,0 & 23,3 & 4,2 \\
\hline Wartościowe gadżety & 6,7 & 11,7 & 26,7 & 20,8 & 7,5 \\
\hline Bony towarowe & 9,1 & 20,8 & 27,5 & 10,8 & 5,8 \\
\hline Promocje & 0,8 & 0,8 & 4,2 & 1,7 & 0,8 \\
\hline Brak danych & 70,0 & 50,0 & 44,2 & 60,8 & 88,3 \\
\hline
\end{tabular}

Źródło: badania własne. 


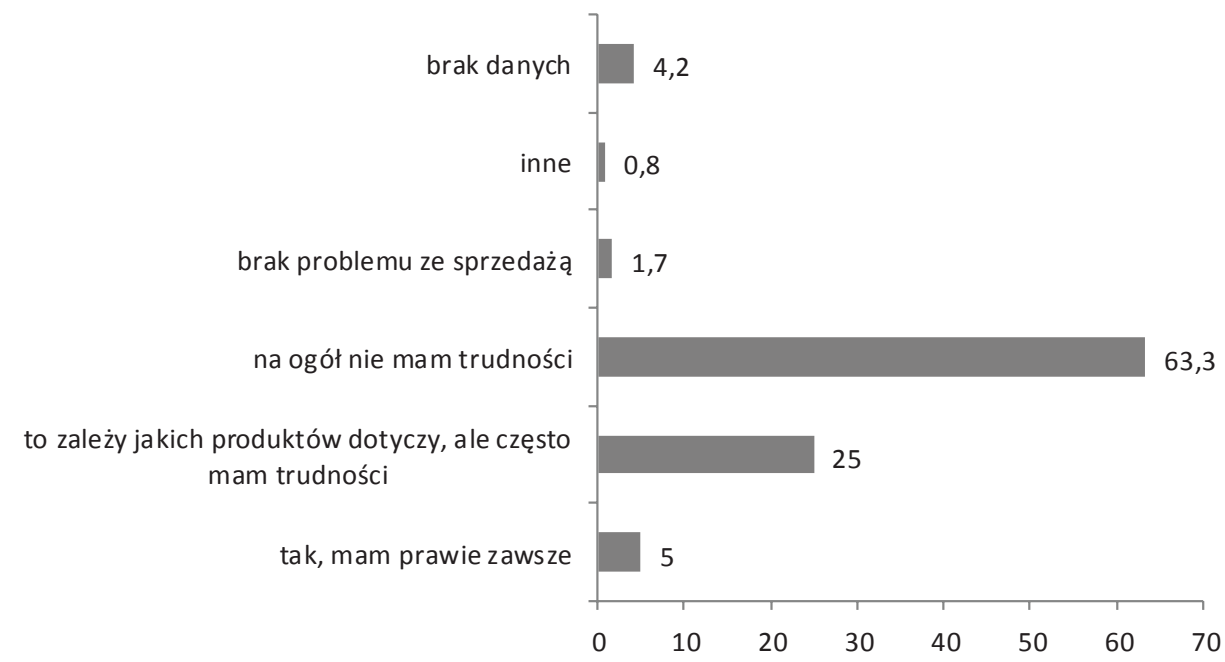

Rysunek 5. Odsetek rolników deklarujących problemy ze sprzedażą produktów

Figure 5. The percentage of farmers declaring problems with the sale of products

Źródło: opracowanie na podstawie badań własnych.

Jednak $25 \%$ rolników wskazało, że często mają problemy ze sprzedażą, a 5\% ma zawsze problemy. Może to być wynikiem oferowania małej partii produktów o gorszej jakości. Ponadto gospodarstwa mogły nie przeprowadzić inwestycji w zakresie magazynowania czy transportu produktów rolnych.

Jak podał Klepacki [2016], głównym problemem w rozwoju logistyki jest rozproszenie producentów i dostawców, co utrudnia współpracę uczestnikom rynku. Sprawne funkcjonowanie rynku jest ograniczone przez słabą organizację, trudności w transporcie oraz niewystarczającą integrację producentów żywności [Pawlewicz i Gotkiewicz 2012].

\section{Wnioski}

Przeprowadzone badania nie wyczerpują podjętej problematyki, ale na ich podstawie można sformułować kilka wniosków.

Badania wykazały, że coraz więcej właścicieli gospodarstw roślinnych współpracuje z więcej niż z jednym dostawcą i z jednym odbiorcą. Stan taki wynika z potrzeby tworzenia kontaktów i relacji między podmiotami w łańcuchach dostaw. Posiadanie większej liczby dostawców i odbiorców stanowi zabezpieczenie w funkcjonowaniu gospodarstw roślinnych.

Objęte badaniami gospodarstwa współpracują w sprzedaży wytworzonych produktów rolnych z pośrednikami $(45,8 \%)$ albo kierują swoje produkty bezpośrednio do przedsiębiorstw przetwórczych (45\%). Różne kanały dystrybucji produkcji roślinnej wynikają z różnej skali produkcji roślinnej w gospodarstwach. Gospodarstwa małe częściej korzystają z usług pośredników, a duże sprzedają swoją produkcję do przedsiębiorstw przetwórczych. 
W rozwoju logistyki ważne są źródła informacji, która w dobie rozwiniętej konkurencji rynkowej należy do wartościowych zasobów, a jej zdobycie jest kosztowne. Głównym źródłem informacji o środkach ochrony roślin i nawozach są czasopisma i publikacje, klienci przedsiębiorstwa (po 20,8\%) oraz wewnętrzne informacje firmy (18,3\%). Wynik ten świadczy o potrzebie dostarczenia rolnikom aktualnych informacji oraz o wzroście jej znaczenia w rozwoju gospodarstw roślinnych.

\section{Literatura}

Baran J., Wysokiński M., Jałowiecki P., 2011: Rozwiązanie w zakresie sterowania zapasami w wybranych branżach agrobiznesu, Logistyka 2, 45-54.

Bełdycka-Bórawska A., Szymańska E.J., 2016: Dochodowość gospodarstw o różnych kanałach dystrybucji rzepaku, Zeszyty Naukowe SGGW w Warszawie, Ekonomika i Organizacja Logistyki 1, 31-40.

Jarzębowski S., 2014: Efektywność sektora przetwórstwa zbóż w kontekście organizacji łańcucha dostaw, Zeszyty Naukowe SGGW w Warszawie, Ekonomika i Organizacja Gospodarki Żywnościowej 105, 57-66.

Juchniewicz M., 2015: Innowacje w logistyce łańcucha dostaw żywności, Zeszyty Naukowe Uniwersytetu Szczecińskiego, Problemy Zarządzania, Finansów i Marketingu 41 (2), 473 -482, doi: 10.18276/pzfm.2015.41/2-38

Klepacki B., 2016: Miejsce i znaczenie logistyki w agrobiznesie, Zeszyty Naukowe SGGW w Warszawie, Ekonomika i Organizacja Logistyki 1 (1), 7-18.

Kot S., Starostka-Patyk M., Krzywda D., 2009. Zarządzanie łańcuchami dostaw, Politechnika Częstochowska, Częstochowa.

Pawlewicz A., Gotkiewicz W., 2009: Kanały dystrybucji surowców żywnościowych z gospodarstw ekologicznych w województwie warmińsko-mazurskim, Logistyka 4, 1168-1174 [CD].

Rutkowski K., 2004: Zarządzanie łańcuchem dostaw - próba sprecyzowania terminu i określenia związków z logistyką, Gospodarka Materiałowa i Logistyka 12, 2-8.

Stańko S., 2007: Tendencje na rynku zbóż, [w:] Czy grozi Polsce kryzys zbożowy (w świetle pozarolniczego wykorzystania ziarna), B. Klepacki (red.), Wieś Jutra, Warszawa.

Turner J.R., 1993: Integrated Supply Chain Management: What's Wrong WITH This Picture?, Industrial Engineering 25 (12), 52-55.

Adres do korespondencji:

mgr Aneta Bełdycka-Bórawska

(https://orcid.org/0000-0002-1398-0082)

Uniwersytet Warmińsko-Mazurski w Olsztynie

Wydział Kształtowania Środowiska i Rolnictwa

Katedra Agrotechnologii, Zarządzania Produkcją Rolniczą i Agrobiznesu

Plac Łódzki 2, 10-957 Olsztyn

e-mail: aneta.beldycka-borawska@uwm.edu.pl 



\title{
Ekonomika i Organizacja Logistyki \\ 3 (3), 2018, 25-35
}

DOI: 10.22630/EIOL.2018.3.3.19

\author{
Teresa Gadek-Hawlena ${ }^{1}$, Marcelina Los ${ }^{2}$ \\ ${ }^{1}$ Uniwersytet Ekonomiczny w Katowicach \\ ${ }^{2}$ Mar-Kor sp. z o.o., Gliwice
}

\section{Nowoczesne rozwiązania w pojazdach ciężarowych i ich wpływ na bezpieczeństwo ruchu drogowego Modern solutions in heavy goods vehicles
and their influence on road safety}

Synopsis. Z powodu ogromnej liczby wypadków i ich negatywnych konsekwencji działania na rzecz poprawy bezpieczeństwa ruchu drogowego powinny obejmować wszystkie grupy uczestników ruchu drogowego. Liczba wypadków drogowych powodowanych przez kierowców samochodów ciężarowych utrzymuje się na wysokim poziomie, a ich najczęstszą przyczyną jest zmęczenie. Producenci samochodów ciężarowych chcąc zmienić te realia, wprowadzają wiele nowoczesnych rozwiązań wpływających na wzrost bezpieczeństwa pojazdów oraz na komfort jazdy. $\mathrm{W}$ artykule zaprezentowano wyniki badań, których celem było określenie typów niebezpiecznego zachowania kierowców zawodowych oraz ocena wprowadzanych w pojazdach ciężarowych rozwiązań wpływających na bezpieczeństwo ruchu drogowego.

Słowa kluczowe: bezpieczeństwo ruchu drogowego, pojazdy ciężarowe, kierowcy zawodowi

\begin{abstract}
Actions taken for the betterment of road safety, due to the sheer number of accidents and their consequences, should include all groups of road users. The number of road accidents caused by heavy goods vehicles (HGVs) drivers still maintains a high percentage, and the main contributing factor is their weariness. In order to positively influence this situation, HGV manufacturers provide many modern, high-tech solutions which have direct effect on both safety and comfort. The following article provides research data focused on describing various types of professional driver's dangerous behaviours, as well as the summary of solutions implemented to aid road safety in modern HGVs.
\end{abstract}

Key words: road safety, heavy goods vehicles, professional drivers 


\section{Wstęp}

Jak wynika z raportu Organizacji Narodów Zjednoczonych, w wypadkach drogowych każdego roku ginie ponad 1,35 millionów osób, a 50 millionów zostaje rannych [UN 2017]. Stanowi to ogromny problem społeczno-ekonomiczny. Z raportów Światowej Organizacji Zdrowia wynika, że wśród głównych przyczyn zgonów we współczesnym świecie 8. miejsce zajmuje śmierć w wyniku wypadku drogowego, plasując się w rankingu po takich chorobach, jak: niedokrwistość, wylewy, przewlekłe choroby płuc, infekcje dróg oddechowych, choroba Alzheimera, różnego typu demencje starcze, choroby tchawicy, oskrzeli, raku płuc oraz cukrzyca [WHO 2016].

Sytuacja ta powoduje, że w celu podjęcia działań ograniczających skalę zjawiska poszukuje się kluczowych czynników sprawczych wypadków drogowych. Wśród głównych wymienia się: nadmierną prędkość, niebezpieczne zachowania pieszych i rowerzystów, zachowania młodzieży [WHO 2015]. Wypadki wywołane zmęczeniem dotyczą głównie kierowców samochodów ciężarowych. O ile wypadki z udziałem kierowców samochodów osobowych niosą poważne konsekwencje dla osób indywidualnych, o tyle w wypadkach z udziałem samochodów ciężarowych pojawiają się dodatkowe duże koszty dla wielu podmiotów gospodarczych, praktycznie w całym łańcuchu dostaw. Z badań przeprowadzonych w wybranych krajach europejskich wynika, że zmęczenie kierowców stanowi istotny czynnik w około $20 \%$ wypadków w transporcie międzynarodowym. Wyniki wielu badań pokazują, że ponad połowa kierowców jeżdżących na długie dystanse w pewnym momencie zasnęła za kierownicą. Szczytowe poziomy wypadków związanych ze zmęczeniem w nocy są często 10 razy wyższe niż w ciągu dnia. Prowadzone we Francji badania dotyczące godzin pracy i nawyków kierowców ciężarówek wykazały, że ryzyko wypadków związanych ze zmęczeniem wzrastało, gdy jechali nocą, wydłużono ich dzień pracy, pracowali w nieregularnych godzinach [Peden i in. 2004]. Chcąc minimalizować liczbę wypadków powodowanych przez kierowców samochodów wykonujących zawodowo pracę kierowcy, producenci samochodów ciężarowych wprowadzają nowoczesne rozwiązania w pojazdach mające na celu poprawę bezpieczeństwa między innymi poprzez układ monitorowania ruchu, aktywny tempomat z układem ostrzegającym o niebezpieczeństwie kolizji i funkcją awaryjnego hamowania czy system monitorowania reakcji kierowcy.

Celem artykułu była analiza i ocena zachowania kierowców pojazdów ciężarowych o dopuszczalnej masie całkowitej powyżej 3,5 t oraz postrzeganie przez nich wpływu na bezpieczeństwo ruchu drogowego nowoczesnych rozwiązań stosowanych w pojazdach ciężarowych.

W badaniach wykorzystano głównie raporty i opracowania Organizacji Narodów Zjednoczonych i Światowej Organizacji Zdrowia oraz badania wykonane za pomocą kwestionariusza ankiety. Do przedstawienia wyników badań posłużono się analizą częstości.

\section{Metodyka prowadzenia badań}

Temat badania był ściśle związany z kierowcami zawodowymi, więc badanie wykonano wśród jeżdżących samochodami ciężarowymi o dopuszczalnej masie całkowitej powyżej 3,5 t. 
Badanie przeprowadzono za pomocą kwestionariusza ankietowego online, wypełnianego samodzielnie przez ankietowanych. Do doboru próby losowej wykorzystano metodę śnieżnej kuli ${ }^{1}$. Badanie przeprowadzono w czerwcu i lipcu 2018 roku, a przystąpiło do niego 660 osób.

Pierwsza część pytań obejmowała problem typowego zachowania kierowców przyczyniających się do wypadków, a druga dotyczyła doświadczenia w użytkowaniu nowoczesnych systemów bezpieczeństwa i oceny poszczególnych z nich, a także ogólnej oceny nowoczesnych systemów bezpieczeństwa pod względem ich przydatności w pracy.

\section{Charakterystyka próby badawczej}

W badaniu wzięło udział 660 kierowców: 26 kobiet (3,9\%) i 634 mężczyzn (96,1\%). Ankietowani zostali podzieleni na cztery grupy wiekowe: od 18 do 25 lat, od 26 do 45 lat, od 46 do 60 lat oraz powyżej 60. roku życia. Rozkład procentowy respondentów w poszczególnych grupach wiekowych ujęto na rysunku 1.

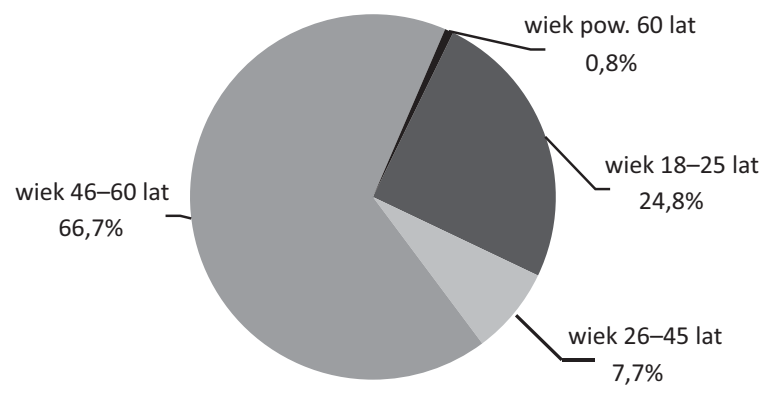

Rysunek 1. Wiek ankietowanych

Figure 1. Age of respondents

Źródło: opracowanie własne.

Wśród wszystkich badanych kierowców najliczniejszą grupę stanowiły osoby w przedziale wiekowym 46-60 lat. Na drugim miejscu znaleźli się młodzi kierowcy, czyli osoby w wieku 18-25 lat - ich udział w ankiecie wynosił 24,8\%. Mniej, bo tylko 7,7\%, stanowiły osoby pomiędzy 26. a 45. rokiem życia. Najmniej liczną grupą ankietowanych byli kierowcy powyżej 60. roku życia. W ankiecie uczestniczyło zaledwie 5 kierowców z tej kategorii wiekowej, co stanowiło 0,8\% wskazań. Biorąc pod uwagę staż pracy, ponad połowę respondentów (51,7\% wskazań) stanowili kierowcy, którzy w zawodzie pracują do 5 lat. Kierowcy mający staż pracy od 5 do 10 lat (27,4\%). Kierowcy ze stażem pracy powyżej 10 lat stanowili 20,9\% badanych.

\footnotetext{
${ }^{1}$ Dobór metodą śnieżnej kuli jest wykorzystywany głównie w badaniach specyficznych, trudno dostępnych grup. Badacz wykorzystujący ten schemat doboru stara się dotrzeć do członków grupy, których relatywnie łatwo można odszukać, a następnie prosi ich o pomoc w rekrutacji innych osób przynależących do tej grupy [Magierowski b.d.].
} 
Blisko połowa ankietowanych (48,9\%) zajmuje się transportem zarówno krajowym, jak i międzynarodowym. Usługi wyłacznie w transporcie międzynarodowym wykonuje 26,1\% ankietowanych, a pozostałe $25 \%$ prowadzi samochody tylko w transporcie krajowym.

Ostatnia kwestia charakteryzująca badanych dotyczyła typu samochodu ciężarowego, jaki prowadzą, wykonując zawód kierowcy (rys. 2). Z uwagi na specyfikę zagadnienia nowoczesnych rozwiązań stosowanych w pojazdach ciężarowych, pod uwagę wzięte zostały tylko samochody ciężarowe o dopuszczalnej masie całkowitej powyżej 3,5 t.

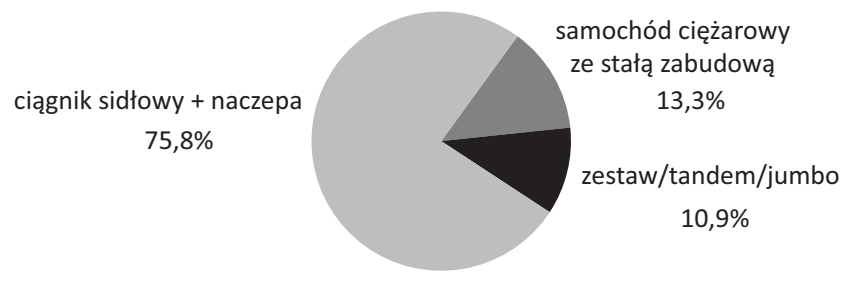

Rysunek 2. Rodzaj pojazdu

Figure 2. Type of vehicle

Źródło: opracowanie własne.

Największą grupę wśród badanych kierowców stanowili kierowcy prowadzący ciągnik siodłowy z naczepą - 75,8\% wskazań. Znacznie mniej kierowców biorących udział w badaniu prowadzi samochód ciężarowy ze stałą zabudową - 13,3\% i na trzecim miejscu - 10,9\% wskazań zostali sklasyfikowani kierowcy zestawów ciężarowych, zwanych również tandemami lub zestawami typu jumbo.

\section{Typy zachowania kierowców zawodowych stwarzających zagrożenie w ruchu drogowym}

W pierwszym pytaniu w tej części badań poproszono kierowców o określenie, jak często zdarza im się przekraczać dopuszczalną na danym obszarze prędkość (rys. 3). Zaledwie 2,6\% respondentów odpowiedziało, że nigdy nie łamie przepisów dotyczących prędkości. Znacznie więcej, bo aż 17,1\% kierowców, stwierdziło, że przekracza dopuszczalną na danym obszarze prędkość, lecz zdarza się im to bardzo rzadko. Do sporadycznego przekraczania dopuszczalnej prędkości przyznało się 29,5\% ankietowanych, a 32,9\% osób zadeklarowało, że robi to często. Grupa kierowców, którzy przyznali się do częstego przekraczania dopuszczalnej prędkości, stanowi 17,9\% ankietowanych.

Kolejne pytanie zadane kierowcom dotyczyło tego, jak często nie zachowują odpowiedniej odległości od pojazdu jadącego przed nimi (rys. 4). Odpowiedniej odległości w stosunku do pojazdów poprzedzających nie zachowuje bardzo często 3,9\% ankietowanych, a często $11,7 \%$ osób. Łącznie stanowi to niespełna $15,6 \%$ wszystkich ankietowanych. Znacznie więcej, bo aż 75,6\% kierowców, odpowiedziało, że zdarza im się robić to rzadko lub bardzo rzadko, a 8,8\% ankietowanych zadeklarowało, że nigdy nie stworzyło zagrożenia w ruchu drogowym $z$ tej przyczyny. 


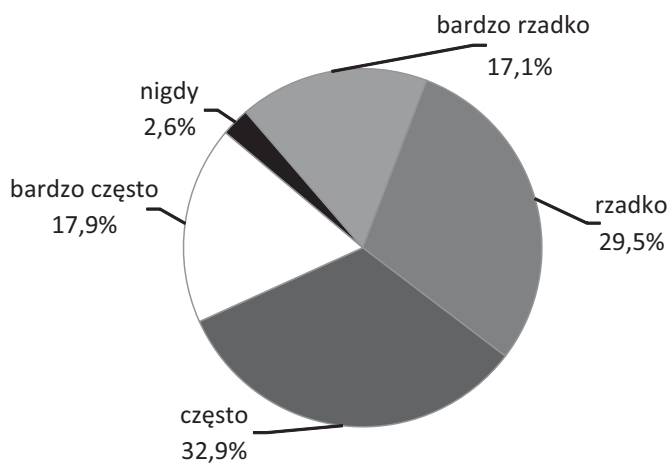

Rysunek 3. Przekraczanie dopuszczalnej prędkości

Figure 3. Exceeding the authories speed

Źródło: opracowanie własne.

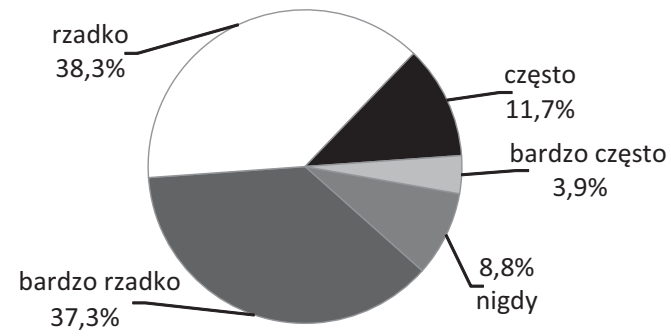

Rysunek 4. Nieodpowiednia odległość od pojazdu poprzedzającego

Figure 4. Inappropriate distance between the preceding vehicle

Źródło: opracowanie własne.

Trzecie pytanie było związane z kwestią zmiany pasów bez użycia kierunkowskazu (rys. 5). $\mathrm{Z}$ odpowiedzi na to pytanie wynika, że aż $82,9 \%$ ankietowanych nigdy nie zmienia pasa ruchu bez użycia kierunkowskazu lub robi to bardzo rzadko. Ponaddwukrotnie mniej ankietowanych $(12,9 \%)$ robi to rzadko. W grupach stwarzających realne ryzyko powstania zdarzenia drogowego są osoby, które sklasyfikowały swoje zachowanie jako częste oraz bardzo częste. W przypadku ankietowanych było to łącznie $4,2 \%$ osób, z czego zaledwie 2 osoby przyznały, że bardzo często zdarza im się zmieniać pas ruchu, nie sygnalizując tego w odpowiedni sposób.

Kolejną kwestią $\mathrm{w}$ tej części ankiety był problem przyczyn występowania $\mathrm{z}$ ich winy zdarzeń drogowych (rys. 6). Pytanie umożliwiało wielokrotny wybór. Łącznie ankietowani udzielili na to pytanie 1850 odpowiedzi. Każdy badany udzielił średnio 2-3 odpowiedzi. Według nich najczęstszą przyczyną zdarzeń drogowych było nieodpowiednie zachowanie innych uczestników ruchu drogowego. Sądzi tak blisko 64\% ankietowanych. Nieco mniejszą liczbę głosów, bo $63,8 \%$, oddano na zdarzenia drogowe wynikające z osłabionej reakcji w wyniku zmęczenia. Prawie połowa (48,5\%) uważała, że przyczyną 


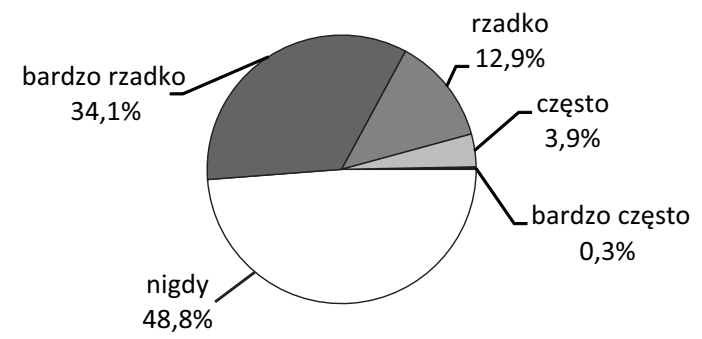

Rysunek 5 . Zmiana pasa ruchu bez użycia kierunkowskazu

Figure 5. Change of lane without using the turn signal

Źródło: opracowanie własne.

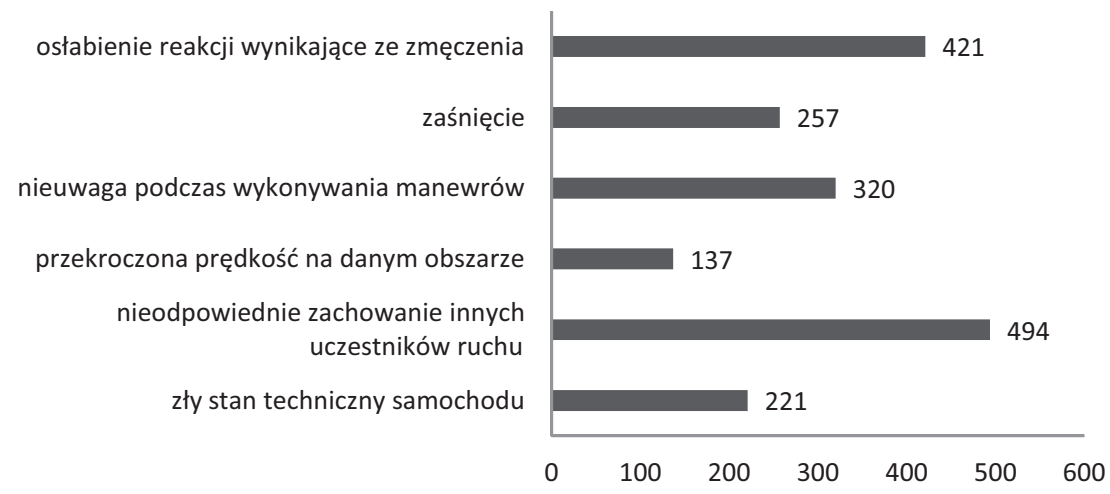

Rysunek 6. Ocena przyczyn zdarzeń drogowych zdaniem kierowców

Figure 6. Assessment of causes of road events according to drivers

Źródło: opracowanie własne.

zdarzenia drogowego była nieuwaga podczas wykonywania manewrów, a 38,9\% osób opowiedziało się za zaśnięciem za kierownicą. Zły stan techniczny pojazdów ciężarowych 33,5\% ankietowanych kierowców uważa za główną przyczynę zdarzenia drogowego. Zaledwie $20 \%$ jako przyczynę zdarzeń drogowych podało przekroczenie prędkości na danym obszarze, pomimo udzielonej wcześniej odpowiedzi, że zdarza im się przekraczać dozwoloną prędkość. Następnie zapytano badanych, czy byli sprawcami zdarzenia drogowego. Nieco ponad $25 \%$ ankietowanych przyznało, że spowodowało kolizję, kierując samochodem ciężarowym. Znaczna większość to kierowcy w wieku 25-45 lat, ze stażem pracy powyżej 10 lat, kierujący ciągnikiem siodłowym z naczepą. Zdecydowana większość $(81,5 \%)$ ankietowanych kierowców nie spowodowała kolizji ze szkodą rzeczową.

Następnie pytanie dotyczyło kwestii, czy sami byli sprawcami wypadków jako kierujący samochodami ciężarowymi. Spośród wszystkich ankietowanych 1,36\% osób było sprawcą wypadku drogowego (2 kobiety i 7 mężczyzn). Wypadek skutkuje powstaniem nie tylko szkód materialnych, ale także ofiar rannych lub śmiertelnych, dlatego też kie- 
rowców, którzy na powyższe pytanie odpowiedzieli twierdząco, poproszono o określenie rodzaju ofiar w spowodowanym przez nich wypadku. Klasyfikacja ofiar wypadków spowodowanych przez dziewięcioro z ankietowanych przedstawia się następująco:

- 5 osób było sprawcą wypadku, na skutek którego poszkodowani zostali ranni,

- 3 osoby spowodowały wypadek ze skutkiem śmiertelnym,

- 1 osoba była sprawcą wypadku, w którym poza osobami rannymi była również ofiara śmiertelna.

\section{Wpływ nowoczesnych rozwiązań stosowanych w pojazdach ciężarowych na bezpieczeństwo ruchu drogowego}

Kolejna część badań dotyczyła nowoczesnych rozwiązań stosowanych w samochodach ciężarowych, które wykorzystują ankietowani. Celem było zbadanie, czy systemy te są znane kierowcom i jak są przez nich postrzegane z punktu widzenia bezpieczeństwa ruchu drogowego. Pierwsze pytanie miało na celu zidentyfikowanie zainstalowanych nowoczesnych rozwiązań w pojazdach prowadzonych przez kierowców biorących udział w badaniu. Pytanie pozwalało na udzielenie wielokrotnej odpowiedzi, a wyniki zaprezentowano na rysunku 7. Z nowoczesnymi systemami poprawiającymi bezpieczeństwo $48 \%$ ankietowanych kierowców do tej pory nie miało do czynienia. Pozostali respondenci $(56,7 \%)$ mieli w swoich samochodach zainstalowany przynajmniej jeden z wymienionych w ankiecie systemów. Najwięcej, bo 41,2\% badanych, prowadziło pojazd wyposażony w układ monitorowania pasa ruchu². Samochód wyposażony w aktywny tempomat przewidujący drogę miało $42 \%$ ankietowanych ${ }^{3}$. Samochód doposażony w układ zmiany pasa ruchu prowadziło $17,9 \%$ respondentów, a 14,2\% z nich miało pojazd dodatkowo wyposażony w układ monitorujący reakcję kierowcy ${ }^{4}$.

Następnie zapytano kierowców, czy wystąpiła u nich sytuacja, w której dzięki poprawnemu zadziałaniu aktywnego systemu bezpieczeństwa nie doszło do spowodowania zdarzenia drogowego. W ankietowanej grupie 43,3\% osób nie wypowiedziało się na temat nowoczesnych systemów bezpieczeństwa w pojazdach ciężarowych, ponieważ nie miało z nimi styczności. Sytuacja, kiedy dzięki poprawnemu zadziałaniu systemu bezpieczeństwa nie doszło do zdarzenia drogowego, przydarzyła się 30,6\% respondentów, a 26,1\% osób nie miało takich doświadczeń.

Zadano również pytanie, czy zdarzyła się sytuacja, kiedy mimo posiadania nowoczesnego systemu bezpieczeństwa w samochodzie nie zadziałał on w poprawny sposób, przez co doszło do wypadku lub kolizji. Podobnie jak w przypadku poprzedniego

\footnotetext{
${ }^{2}$ Funkcja monitorowania pasa ruchu może pomagać prowadzącemu samochód, kierując pojazd z powrotem na właściwy pas ruchu i/lub ostrzegając za pomocą sygnałów akustycznych lub wibracji kierownicy [Volvo Cars Poland 2019].

${ }^{3}$ Aktywne tempomaty w nowoczesnych samochodach utrzymują właściwą odległość od poprzedzającego pojazdu, wyręczając kierowcę w przyspieszaniu i zwalnianiu. Odstęp między pojazdami można regulować - najczęściej jest on 3-5-stopniowy. Aktualnie instalowane systemy potrafią też całkowicie zatrzymać samochód, a następnie ruszyć nim, utrzymując zarówno prędkość, jak i zadaną odległość od auta jadącego przed nami [Mielniczak 2018].

${ }^{4}$ Monitoring ten polega na rejestrowaniu ruchu gałek ocznych kierowcy za pomocą kamery skierowanej na jego twarz. Są to systemy wspomagające pracę kierowcy [Volvo Trucks Poland b.d.].
} 


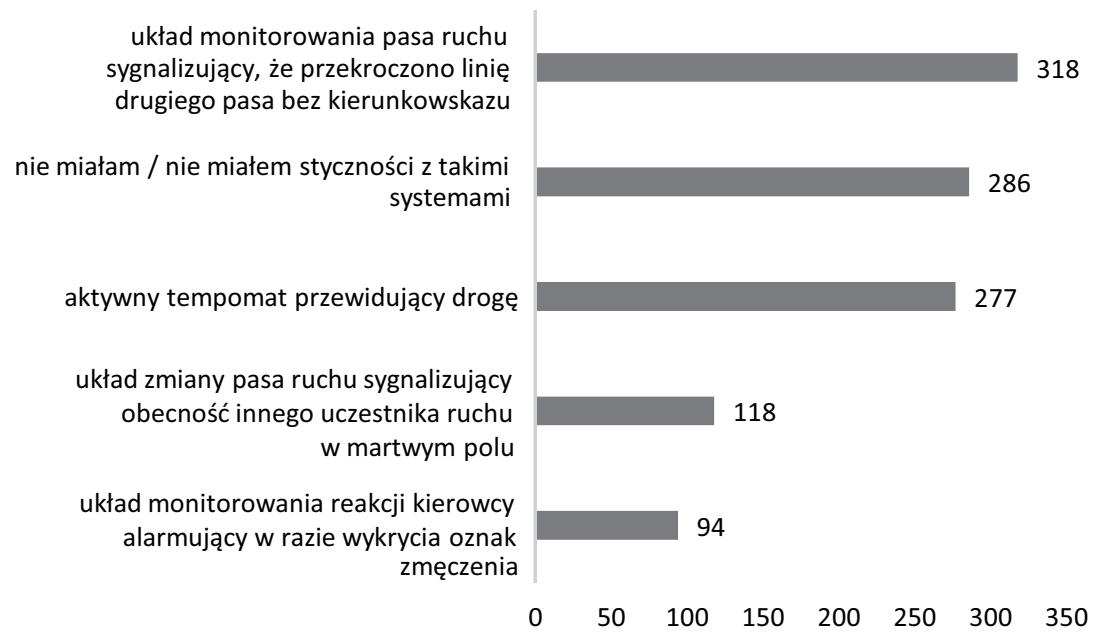

Rysunek 7. Rodzaje systemów poprawiających bezpieczeństwo pojazdu

Figure 7. Types of systems improving vehicle safety

Źródło: opracowanie własne.

pytania, 43,3\% ankietowanych nie udzieliło odpowiedzi potwierdzającej ani zaprzeczającej ze względu na brak styczności z tego rodzaju systemami. Z incydentem, kiedy zainstalowany $w$ ich samochodzie system bezpieczeństwa nie zadziałał poprawnie, miało do czynienia 50,9\% ankietowanych. Tylko 9 ankietowanych spowodowało zdarzenie drogowe w wyniku niepoprawnego działania zainstalowanego systemu. Ta ostatnia grupa kierowców została poproszona o sprecyzowanie, który z systemów zawiódł. Najczęściej udzielaną odpowiedzią było niepoprawne działanie aktywnego tempomatu przewidującego drogę. Respondenci kilkakrotnie wskazali, że w wyniku błędnej interpretacji otoczenia wokół pojazdu samochód gwałtownie zahamował, co spowodowało wyprowadzenie pojazdu z odpowiedniego toru ruchu, czego skutkiem były kolizje $\mathrm{z}$ pojazdami jadącymi z tyłu. $\mathrm{U}$ jednego $\mathrm{z}$ ankietowanych nie zadziałał asystent zmiany pasa ruchu, co stało się przyczyną kolizji bocznej.

Kolejne pytanie w tej części ankiety dotyczyło oceny przydatności każdego z oferowanych przez producentów ciężarówek nowoczesnego systemu bezpieczeństwa w skali od 1 do 5 , gdzie 1 oznacza nieprzydatny, a 5 - bardzo przydatny (rys. 8). Pierwszym z ocenianych systemów był układ monitorowania pasa ruchu. Jako bardzo przydatny system uznało go $33 \%$ ankietowanych, za przydatny $12 \%$, za raczej przydatny $25 \%$, a za niezbyt przydatny $16 \%$ osób. Układ monitorowania pasa ruchu $14 \%$ ankietowanych kierowców uważa, że w niczym nie ułatwia im pracy. Drugim ocenianym systemem był układ zmiany pasa ruchu. W tym przypadku również najwyższa ocena zyskała najwięcej głosów - $33 \%$. Pozostałe odpowiedzi dzielą się odpowiednio na $13 \%$ dla oceny $4,22 \%$ głosów na ocenę $3,17 \%$ głosów na ocenę 2 . Za nieprzydatny w pracy uznało go $15 \%$ ankietowanych. Trzecim ocenianym systemem był układ monitorowania reakcji kierowcy. W tym przypadku (podobnie jak w poprzednim) 15\% kierowców uznało, że jest on nieprzydatny lub niezbyt przydatny. Pozostałe głosy rozłożyły się następująco: $23 \%$ kierowców uznało 


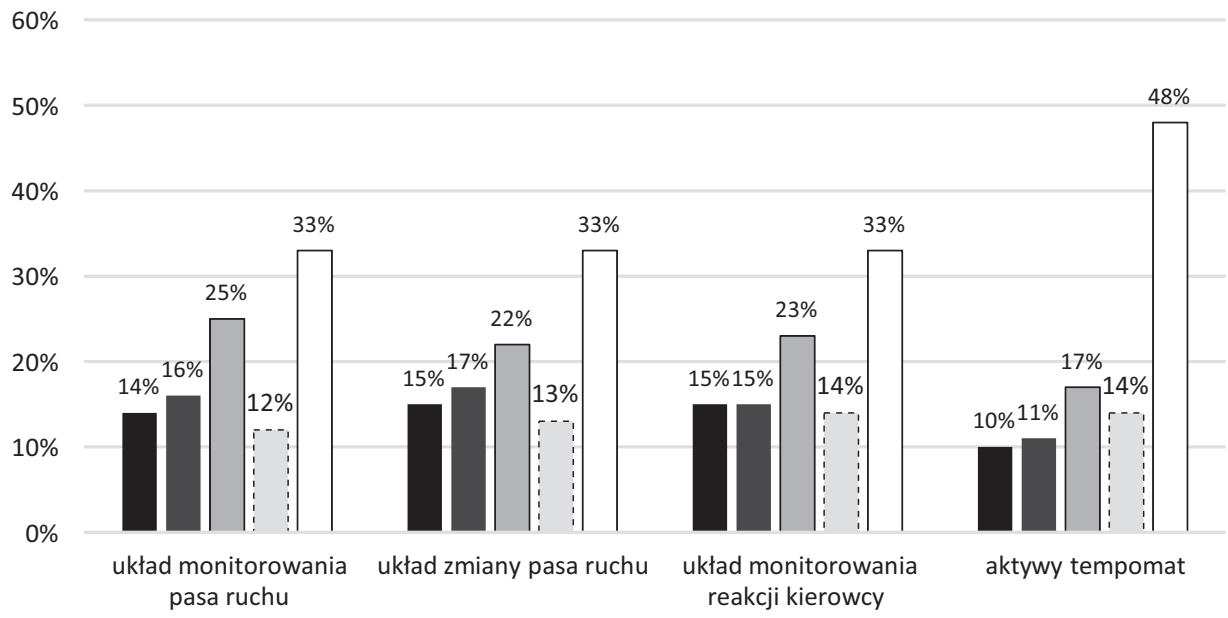

$\square 1 \square 2 \square 3: \square \square 5$

Rysunek 8. Przydatność nowoczesnych systemów bezpieczeństwa w pojeździe

Figure 8 . The usefulness of modern vehicle safety systems

Źródło: opracowanie własne.

system za raczej przydatny, 14\% sądziło, że jest on przydatny, a zdaniem 33\% jest bardzo przydatny w ich pracy. Czwarty oceniany przez kierowców system to aktywny tempomat przewidujący drogę. Zyskał on największą przychylność głosujących: aż 48\% badanych uznało go za bardzo przydatny w pracy, 14\% kierowców oceniło go jako przydatny, 17\% uznało go za raczej przydatny, a 21\% kierowców rozdzieliło głosy pomiędzy oceny „,niezbyt przydatny" (11\%) i ,nieprzydatny” (10\%).

Dodatkowo podjęto się rozpoznania przydatności nowoczesnych systemów bezpieczeństwa $\mathrm{w}$ pojazdach ciężarowych. Pierwsze pytanie z tej części dotyczyło opinii kierowców, czy tego typu systemy wspierają ich pracę. Zdaniem 69,9\% respondentów nowoczesne systemy bezpieczeństwa wspierają kierowców w pracy. Na ten temat $23,8 \%$ osób biorących udział w badaniu nie miało zdania, a $6,4 \%$ badanych uznała, że nie wspierają ich one w czasie pracy. Wśród ankietowanych, którzy udzielili odpowiedzi negatywnej, znalazło się 12 kierowców, którzy wykonują przewozy na terenie kraju, 16 wykonujących przewozy krajowe i międzynarodowe i 18 zajmujących się przewozami wyłącznie międzynarodowymi. Zdaniem 32,1\% respondentów nowoczesne systemy bezpieczeństwa oferowane przez producentów samochodów ciężarowych zbyt mocno ingerują w ich pracę i zbyt często wpływają na decyzje dotyczące manewrów wykonywanych w czasie jazdy. Znaczna liczba ankietowanych kierowców $(67,9 \%)$ stwierdziła, że systemy te nie mają znacznego wpływu na pracę w ich zawodzie.

Ostatnie pytanie, nawiązujące do poprzedniego, dotyczyło wpływu nowoczesnych systemów bezpieczeństwa na umiejętności młodych kierowców samochodów ciężarowych. Zapytano ankietowanych, czy ich zdaniem młodzi kierowcy polegają wyłącznie na działaniu systemów komputerowych, bez szkolenia własnych umiejętności. Z założeniem, że młodzi kierowcy zbyt mocno polegają na działaniu inteligentnych systemów 
bezpieczeństwa, w związku z czym nie rozwijają swoich umiejętności, zgodziło się $66,5 \%$ ankietowanych kierowców. Nieco ponad $1 / 3$ badanych $(33,5 \%)$ nie zgodziła się z powyższą tezą. W tej kwestii istotna była przede wszystkim opinia kierowców o długim stażu zawodowym. Wśród ankietowanych, których staż zawodowy przekraczał 10 lat, aż 135 odpowiedziało, że zgadzają się z oceną, iż tego typu systemy negatywnie wpływają na doświadczenia i nawyki młodych kierowców.

\section{Podsumowanie i wnioski}

Na podstawie przeprowadzonych badań można sformułować kilka wniosków i uogólnień:

1. Poprawa bezpieczeństwa ruchu drogowego jest koniecznością. Działania w tym zakresie powinny być nakierowane na identyfikację przyczyn i poszukiwanie najskuteczniejszych rozwiązań. W przypadku kierowców pojazdów ciężarowych rozwiązania takie powinny dotyczyć między innymi pojazdów, które należy wyposażać w nowoczesne systemy bezpieczeństwa ograniczające możliwości popełnienia błędu przez kierowcę.

2. Kierowcy pojazdów ciężarowych prowadzących pojazdy o dopuszczalnej masie całkowitej powyżej 3,5 t jako najczęstsze przyczyny swojego niebezpiecznego zachowania wskazują: przekroczenie dopuszczalnej prędkości, osłabienie reakcji wynikającej z powodu zmęczenia, nieuwagę podczas wykonywania manewrów oraz zaśniecie. Wśród pozostałych czynników niezależnych od nich, a mogących doprowadzić do kolizji lub wypadku wymieniali: nieodpowiednie zachowanie innych uczestników ruchu drogowego i zły stan techniczny pojazdu.

3. Pomimo rozwoju nowoczesnych systemów bezpieczeństwa w pojazdach ciężarowych ponad połowa badanych kierowców nie korzystała z tego typu systemów ze względu na tabor, którym wykonują przewozy. W pojazdach, w których zainstalowany był przynajmniej jeden system bezpieczeństwa, najczęściej działał on poprawnie i wpływał na bezpieczeństwo jazdy.

4. Wśród nowoczesnych systemów bezpieczeństwa zainstalowanych w pojazdach ciężarowych najlepiej oceniany jest aktywny tempomat. Pozostałe systemy zyskały gorsze oceny. W każdym jednak przypadku odpowiedzi pozytywne przeważały nad negatywnymi. Taki rozkład odpowiedzi może być efektem braku doświadczenia w korzystaniu z tego typu systemów.

5. Większość respondentów uważa, że nowoczesne systemy bezpieczeństwa w pojazdach ciężarowych są przydatne i nie ograniczają możliwości pracy kierowców. Jednocześnie wskazali oni, że młodzi kierowcy bardzo często polegają na działaniu nowoczesnych systemów, a nie na posiadanych umiejętnościach, i dlatego nie podnoszą swoich kwalifikacji, co może wpływać na negatywne nawyki tej grupy kierowców. Celowe wydaje się więc prowadzenie częstych szkoleń wpływających na wzrost umiejętności tej grupy kierowców.

6. Rozwój nowoczesnych systemów bezpieczeństwa w pojazdach ciężarowych jest nieunikniony - według respondentów są one przydatne, jednak producenci pojazdów ciężarowych powinni w miarę możliwości dostosowywać oferty cenowe do możliwości nabywczych przewoźników skłonnych do wymiany taboru na bardziej bezpieczny. 


\section{Literatura}

Mielniczak J., 2018: Aktywny (adaptacyjny) tempomat. Wady, zalety, zasada działania, [źródło elektroniczne] https://www.motofakty.pl/artykul/aktywny-adaptacyjny-tempomat-wadyzalety-zasada-dzialania.html [dostęp: 11.12.2018].

Peden M., Scurfield R., Sleet D., Dinesh Mohan D., Hyder A.A., Jarawan E., Mathers C., 2004: World report on road traffic injury prevention, WHO, Geneva, [źródło elektroniczne] https://whqlibdoc.who.int/publications/2004/9241562609.pdf [dostęp: 11.12.2018].

Magierowski M. [b.d.]: Dobór próby, [źródło elektroniczne] http://researchonline.pl/baza/czytaj/ podkategoria/42 [dostęp: 11.12.2018].

United Nations, 2017: Save LIVES. A road safety technical package, Geneva, [źródło elektroniczne] https://apps.who.int/iris/rest/bitstreams/1083500/retrieve [dostęp: 11.12.2018].

Volvo CarsPoland, 2019:FunkcjaPilotAssistifunkcjamonitorowania pasaruchu, [źródło elektroniczne]https://www.volvocars.com/pl/support/article/3395a91b40bddd9ac0a801511916dab3 [dostęp: 11.12.2018].

Volvo Trucks Poland [b.d.]: Systemy wspomagające pracę kierowcy, [źródło elektroniczne] https:// www.volvotrucks.pl/pl-pl/trucks/volvo-fh/features/driver-support-systems.html [dostęp: 11.06.2018].

World Health Organization, 2015: European facts and the global status report on road safety 2015, Geneva.

World Health Organization, 2016: Top 10 causes of death, Geneva, [źródło elektroniczne] http://www.who.int/gho/mortality_burden_disease/causes_death/top_10/en/ [dostęp: 20.08.2018].

Adres do korespondencji:

dr Teresa Gądek-Hawlena

(https://orcid.org/0000-0003-4350-1246)

Uniwersytet Ekonomiczny w Katowicach

Wydział Ekonomii

Katedra Transportu

ul. 1 Maja 50, 40-287 Katowice tel.: (+48) 322577530

e-mail: gadek@ue.katowice.pl

mgr Marcelina Los

Mar-Kop sp. z o.o.

ul. Zwycięstwa 14/105, 44-100 Gliwice e-mail: marcelina.los@wp.pl 



\title{
Ekonomika i Organizacja Logistyki \\ $3(3), 2018,37-49$
}

DOI: 10.22630/EIOL.2018.3.3.20

\author{
Aleksandra Górecka, Izabela Waśniowska \\ Szkoła Główna Gospodarstwa Wiejskiego w Warszawie
}

\section{Doskonalenie przepływów w kanale dystrybucji na przykładzie piekarni}

\author{
Flows improving in the distribution system \\ on the example of a bakery
}

\begin{abstract}
Synopsis. Organizacja dystrybucji produktów w przedsiębiorstwie to ostatnie ogniwo w procesie logistycznym, które finalizuje poprzedzające działania związane z wytworzeniem produktów. Proces dystrybucji umożliwia bowiem dostarczenie produktów na rynek zgodnie z oczekiwaniami klientów. Każdy rodzaj produktu ma swoje cechy, które należy uwzględnić przy planowaniu jego dystrybucji. Szczególne skomplikowana jest dystrybucja produktów szybko tracących świeżość, do których należą wyroby piekarniczo-cukiernicze. Celem głównym badań było zdiagnozowanie systemu dystrybucji w Piekarni Wierzbica oraz wskazanie możliwości jego usprawnienia. Analizie poddano organizację systemu dystrybucji i określono problemy przedsiębiorstwa $\mathrm{w}$ tym zakresie. Zaproponowano zmiany, które maja potencjał zmniejszenia całkowitych kosztów dystrybucji produktów o 36,41\% ograniczenie floty o dwa pojazdy, co z kolei umożliwi zwiększenie wartości współczynnika wypełnienia pojazdów o 38 punktów procentowych.
\end{abstract}

Słowa kluczowe: dystrybucja, transport, sieć dostaw

\begin{abstract}
The organization of product distribution in the enterprise is the last cell in the logistics process that finalizes the pre-existing activities related to the products production. The distribution process makes possible delivering the products to the market in accordance with the customers' needs. Each type of product has its own features that should be considered when planning their distribution. The distribution of the products which lose their freshness quickly, for example bread, seems to be an interesting case to investigate. The main objective of the research was to discuss the bread distribution system at Wierzbica Bakery and to indicate the possibilities of its improvement. The organization of the distribution system was analysed and the company's problems in this area were identified. The results present that the improvement of changes allows to decrease the distribution costs by $36.41 \%$, to reduce the fleet by two vehicles, which in turn contributes to increase the vehicle load factor rate by 38 percentage points.
\end{abstract}

Key words: distribution, transport, supply network 


\section{Wstęp}

Działania z zakresu dystrybucji wymagają ścisłej współpracy z pozostałymi ogniwami łańcucha dostaw [Baran i in. 2008]. Proces dystrybucji jest nieodłącznym elementem każdego systemu logistycznego i wynika z dwóch podstawowych przesłanek [Ficoń 2001]:

- konieczności zmniejszenia kosztów dystrybucji w związku ze wzrostem konkurencji oraz spadkiem rentowności przedsiębiorstw,

- możliwości zwiększenia przewagi konkurencyjnej poprzez podniesienie standardów obsługi klienta i jakości wyrobu.

Zadaniem dystrybucji jest dostarczenie pożądanego produktu we właściwe miejsce, w odpowiednim czasie, w wymaganej przez klienta ilości i jakości. Z dystrybucją ściśle związany jest problem transportu i dostaw produktów - bezpośrednio do klienta, centrów magazynowych, hurtowni, sklepów detalicznych itp. Transport to kluczowy proces w systemie dystrybucji i szczególnie ważne są jego organizacja i planowanie dla produktów spożywczych szybko psujących się lub tracących świeżość [Górecka i Rokicki 2014]. Do takich zalicza się wyroby piekarniczo-cukiernicze. Istotną kwestią w systemie dystrybucji są sieci dostaw, które ze względu na nasilającą się konkurencję muszą stawać się coraz bardziej efektywne.

Rynek piekarniczy w Polsce jest bardzo rozdrobniony i żaden z liderów nie kontroluje nawet 2\% rynku. W 2009 roku w Polsce funkcjonowało 6029 piekarń [GUS 2013], a w 2016 roku działało 5228 podmiotów [GUS 2018]. W sektorze piekarniczym można zauważyć zarówno brak chętnych do pracy, jak i do nauki tego zawodu. Pogarszająca się kondycja piekarni przejawia się obniżaniem się wolumenu sprzedaży i wolnymi mocami produkcyjnymi, słabnącą rentownością oraz brakiem środków i zdolności do prowadzenia inwestycji [Gorzelany-Dziadkowiec 2012].

Według danych o rozwoju branży piekarskiej w Polsce [Bębenek 2015] spożycie pieczywa spada. W 2015 roku wartość ta wyniosła 47,8 kg na osobę. Jest to prawie o $2 \mathrm{~kg}$ mniej niż w roku poprzednim. Dla porównania w 2005 roku wartość ta bliska była $70 \mathrm{~kg}$. Mimo napotykanych problemów potencjał tej branży jest wciąż duży. Dbałość o potrzeby klientów przejawia się między innymi wzrostem różnorodności asortymentu. Producenci wychodzą naprzeciw oczekiwaniom konsumenckim, co może zaowocować w przyszłości poprawą trendu.

\section{Cele i metody badawcze}

Celem głównym badań było zdiagnozowanie systemu dystrybucji pieczywa w Piekarni Wierzbica oraz wskazanie możliwości jego usprawnienia Przed przystąpieniem do badań przyjęto następujące hipotezy badawcze:

- H1: Konfiguracja sieci dostaw w piekarni pozwala na zmniejszenie kosztów transportu.

- H2: Wzrost wykorzystania ładowności środków transportu w badanym przedsiębiorstwie pozwoli na zmniejszenie ich liczby. 
Artykuł zawiera elementy rozwiązań uniwersalnych dla większości przedsiębiorstw, ale studium obejmuje konkretny przypadek - piekarnię - firmę specyficzną ze względu na charakter prowadzonej działalności oraz produkty finalne oferowane konsumentom.

$\mathrm{W}$ badaniach wykorzystano dane pierwotne i wtórne. Do pierwszej grupy zakwalifikowano dane pozyskane $\mathrm{z}$ dokumentów firmy oraz wywiadu bezpośredniego z przedstawicielem przedsiębiorstwa, które dotyczyły flot, zatrudnienia, sieci sklepów oraz organizacji dystrybucji. Do obliczenia kosztów transportu zastosowano w badaniach układ rodzajowy kosztów [Urbanyi-Popiołek 2013]: amortyzację pojazdów drogowych, wynagrodzenia kierowców, narzuty na wynagrodzenia, zakup i zużycie materaców jezdnych i olejów, zakup i zużycie ogumienia, ubezpieczenia pojazdów i ładunków. Wartości te zostały oszacowane przez przedstawiciela przedsiębiorstwa podczas wywiadu bezpośredniego. Założono również, że minimalny współczynnik wypełnienia samochodów to $80 \%$. Dane wtórne zgromadzono na podstawie artykułów naukowych o dystrybucji żywności oraz produktów wrażliwych, literatury z zakresu szeroko pojętej logistyki, dystrybucji, zarządzania logistycznego i teorii optymalizacji.

Do analizy danych wykorzystano metodę symulacji, która pozwoliła zaplanować nową sieć dostaw w firmie oraz statystykę opisową.

\section{Przegląd literatury}

Specyfiką logistyki dystrybucji produktów charakteryzujących się krótkim okresem trwałości jest tematem poruszanym wielokrotnie w literaturze zarówno naukowej, jak i branżowej. Zainteresowanie wydaje się uzasadnione ze względu na wyjątkowe cechy produktów, o których mowa. Bortolini i inni [2016] zauważyli i podkreślili, że w badaniach naukowych wykorzystywanych jest wiele modeli do planowania sieci dystrybucji. Większość zaprojektowana została dla potrzeb optymalizacji dystrybucji poprzez kompromis między poziomem kosztów operacyjnych, czasem dostawy produktów oraz wpływem na środowisko [Blasioli 2011, Rong i in. 2011, Ferrarezi i in. 2013].

Pieczywo wymaga specjalnego sposobu przechowywania i transportu, szczególnie jeśli chodzi o czynnik czasu. Matuszewski i Ratajczak [2003] zwrócili uwagę na to, że warunki stawiane sposobom dostaw takich produktów są zróżnicowane i zmienne, a dodatkowo istnieje potrzeba codziennych terminowych dostaw, gdyż są to produkty spożywcze codziennego użytku. W tym przypadku dostawy odbywają się często i kierowane są w wiele punktów odbioru, tj. niewielkich sklepów detalicznych lub marketów. W przypadku pieczywa konsumenci zwracają szczególną uwagę na jakość (świeżość), dlatego wymagają terminowości dostawy oraz odpowiedniej jego ilości, gdyż jest to dobro podstawowe. Autorzy wskazują, że w warunkach dużej konkurencji zdarza się, że piekarnie muszą stawiać czoła nieplanowanym dostawom ,uzupełniającym”. Zakłady produkcyjne nie chcąc, aby działania takie jak fizyczna dostawa do punktów odbioru przynosiły starty, starają się optymalizować proces dystrybucji i transportu. W przedsiębiorstwach wielozakładowych optymalizacja ta polega przede wszystkim na określeniu zakresu obsługiwanych odbiorców przez poszczególne zakłady produkcyjne. Następnie wyznacza się trasy dostaw dla każdego zakładu produkcyjnego oraz ustala, którzy odbiorcy będą obsługi- 
wani w pierwszej kolejności. Za kryterium optymalizacji można przyjąć czas lub koszty. W przypadku sprzedaży bezpośredniej w miejscu produkcji ten problem nie występuje. Problemy piekarni nie ograniczają się jedynie do zagadnień dystrybucji i transportu, ale również istotne jest dostosowanie zdolności produkcyjnych do panujących warunków i zmiennych potrzeb rynku. Proces wypieku i produkcji należy więc dostosować do terminów dostaw.

Ejsmont [2015] omówił kwestię współpracy piekarni z dużymi sieciami handlowymi. Wskazuje, że aby sprostać wymaganiom dużych graczy, produkcja pieczywa powinna osiągać duże wartości tonażowe. To często przekłada się na jakość oferowanego dobra. Dodatkowo produkcja masowa wiąże się z koniecznością doposażenia zakładu produkcyjnego w nowe urządzenia i maszyny zwiększające zdolność produkcyjną, co wymaga nakładów finansowych. Ponadto deflacja cen oraz coraz ostrzejsza konkurencja na rynku powodują wymuszanie poprzez sieci handlowe na mniejszych zakładach piekarniczych niższych cen sprzedaży produktów. Zyski ze współpracy z sieciami handlowymi często nie są warte inwestycji i współpraca może nie przynieść oczekiwanych efektów.

Pacana i inni [2014] wskazali etapy przygotowania optymalizacji dystrybucji produktów w piekarni. Pierwszym etapem powinna być obiektywna ocena przedsiębiorstwa i jego otoczenia. Proponuje wykorzystanie analizy SWOT lub analizy PEST. Autorzy zaproponowali następujące rozwiązania: nawiązanie współpracy z restauracjami, domami weselnymi, hotelami, stołówkami szkolnymi, stworzenie sklepów firmowych w nowych lokalizacjach, lub wyznaczenie nowej trasy handlu obwoźnego za pomocą metody komiwojażera. Została wykorzystana metoda minimalnego drzewa rozpinającego, metoda drogi do najbliższego sąsiada, metoda sukcesywnego dołączania węzłów. Za kryterium optymalizacji autor przyjął odległość. Po przeprowadzeniu analizy i opracowaniu kilku rozwiązań stwierdzono, iż można ujrzeć wymiernie korzyści tych działań.

Dystrybucyjna produktów w przedsiębiorstwie determinuje wysokość kosztów, na które obejmują całość kosztów fizycznego przepływu materiałów od producenta do klienta. Na ich wysokość wpływają takie czynniki, jak: utrzymanie zapasów, procesy informacyjne, kompletacja i przygotowania ładunku do wysyłki, operacje manipulacyjne towaru czy koordynacja działań w ramach systemu logistycznego [Kadłubek 2012, Żurawska i Kulińska 2015]. Te dzielą się na finansowanie zapasów, koszty transportu, koszty magazynowania oraz koszty obsługi zamówień i administracji dystrybucji (rys.1).

Wydatki na transport obejmują znaczą część (37\%) łącznych kosztów dystrybucji, dlatego też rynek oraz działania konkurencji wymuszają na przedsiębiorcach ich minimalizację. Do kosztów transportu w procesie dystrybucji zaliczają się: koszty paliwa, koszty zatrudnienia, amortyzacja, naprawy i konserwacje, przeglądy techniczne oraz ubezpieczenie OC [Kaczmarczyk 2012].

W agrobiznesie najczęściej wykorzystywaną gałęzią transportu jest transport samochodowy. Z innych gałęzi transportu korzystają jedynie duże przedsiębiorstwa ze względu na odległość rynku zbytu oraz wielkości przewożonych towarów. Często ładunki przewożone są w specjalistycznych środkach transportu, co wpływa na chęć posiadania przez przedsiębiorstwa własnego taboru. Dla małych przedsiębiorstw korzystanie z obcych środków transportu na niewielkim rynku jest ekonomicznie nieefektywne [Baran i Wicki 2011]. 


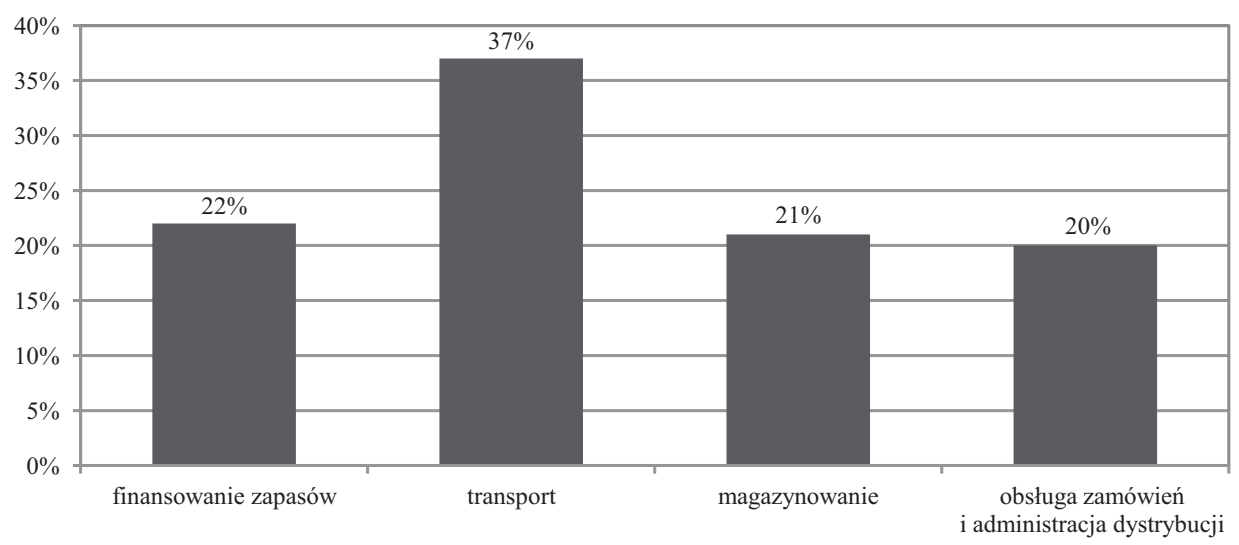

Rysunek 1. Podział kosztów dystrybucji w przedsiębiorstwie

Figure 1. Distribution of distribution costs in the enterprise

Źródło: opracowanie własne na podstawie [Bendkowski i Pietrucha-Pacut 2003].

\section{Charakterystyka przedsiębiorstwa}

Badana piekarnia jest zlokalizowana w województwie lubelskim, w powiecie chełmskim. Jej siedziba główna mieści się w Wierzbicy. Tam też znajduje się jedyny zakład produkcyjny. $Z$ tego punktu nadawany jest transport pieczywa do okolicznych sklepów detalicznych. Piekarnia prowadzi sprzedaż bezpośrednią w swoim zakładzie produkcyjnym oraz zaopatruje swoich stałych klientów w pieczywo i produkty cukiernicze. Firma zatrudnia 25 pracowników, w tym pięciu pracowników jako kierowców. Przedsiębiorstwo jest więc kwalifikowane jako małe.

Dzienna produkcja zakładu piekarniczego wynosi 2-2,5 t, a dzienna zdolność produkcyjna to 3,5 t. Piekarnia swoją działalnością obejmuje obszar do $50 \mathrm{~km}$ od siedziby firmy, a transport w jednym kierunku trwa 20-60 min. Firma nie posiada swoich sklepów firmowych, jednak zaopatruje w pieczywo i wyroby cukiernicze sklepy detaliczne, szkoły, przedszkola, kawiarnie w Chełmie, Rejowców, Żmudzi, Trawnikach, Siedliszczach (rys. 2), do których dostawy odbywają się codziennie. Ilości dostarczanego towaru do restauracji lub domów weselnych i hoteli są niewielkie - wynoszą około 20 sztuk chleba lub innego zamówionego produktu. Dostawy do takich punktów odbywają się 1-2 razy w tygodniu.

Popyt na pieczywo w poszczególnych miastach powoduje, że do większości z nich nadawany jest jeden pojazd przewożący towar. Średni tonaż to: Chełm -60 koszy piekarniczych (900 kg), Żmudź - 20 koszy piekarniczych (300 kg), Rejowiec - 30 koszy piekarniczych (450 kg), Siedliszcze-Trawniki - 50 koszy piekarniczych $(750 \mathrm{~kg})$, Wierzbica - 25 koszy piekarniczych (375 kg). Łącznie tonaż wynosi $2775 \mathrm{~kg}$. Jest to $725 \mathrm{~kg}$ mniej niż dzienna zdolność produkcyjna. Oznacza to, że przy standardowych zamówieniach zdolność wykorzystywana jest w około $80 \%$ (obliczenia są uśrednione i nie obejmują nieplanowanych i nieregularnych dostaw). 


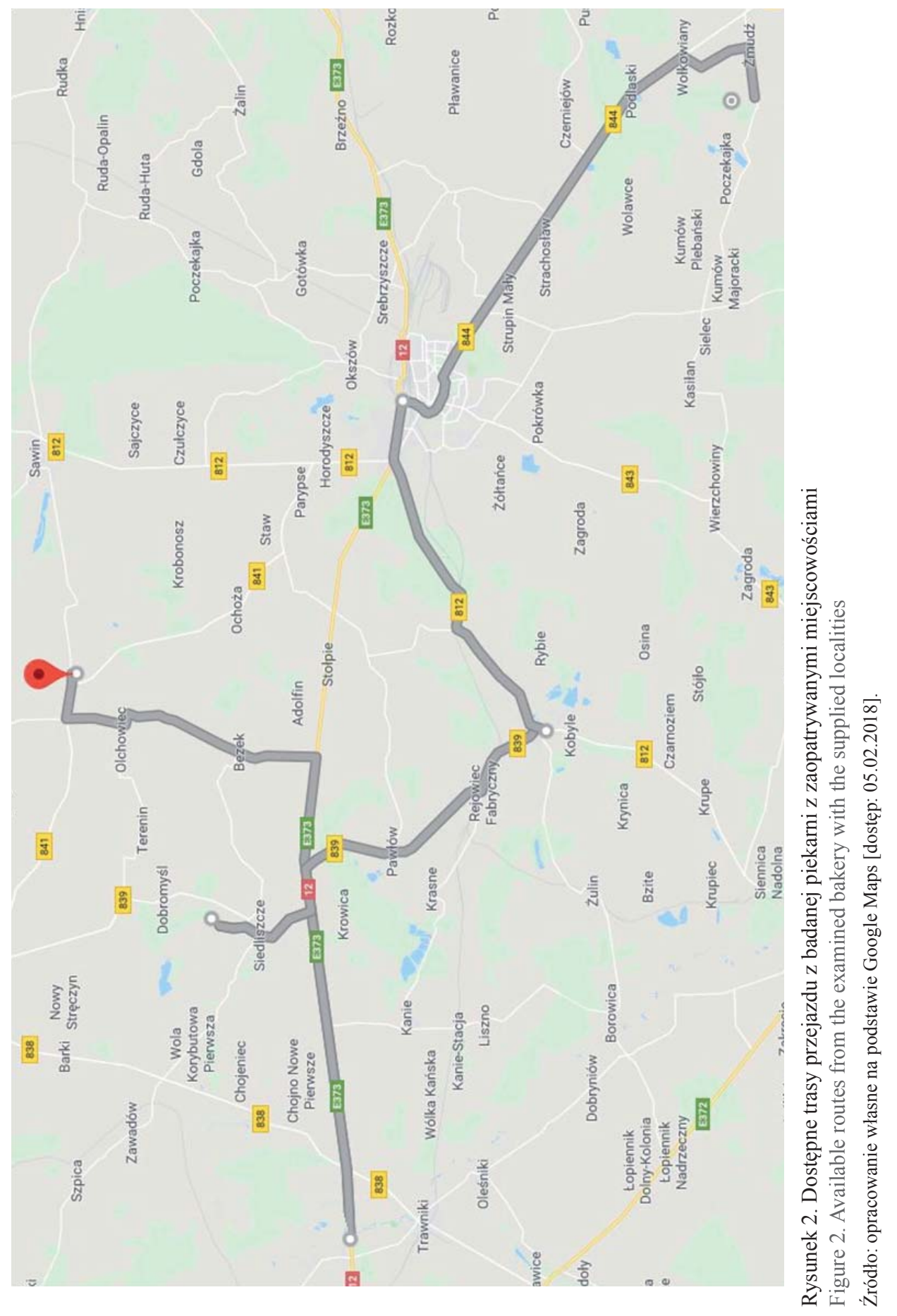


Piekarnia ma flotę składającą się z dwóch samochodów GAZ gazela z izotermą, trzech samochodów daewoo lublin z izotermą oraz jednego samochodu citroen berlingo. Pojazdy mogą pomieścić zróżnicowaną liczbę koszy piekarniczych (tab. 1).

Tabela 1. Ładowność pojazdów floty piekarni

Table 1 . The capacity of the bakery fleet vehicles

\begin{tabular}{|l|c|c|}
\hline Pojazd & $\begin{array}{c}\text { Ladowność } \\
(\mathrm{kg})\end{array}$ & $\begin{array}{c}\text { Liczba koszy piekarniczych } \\
(\text { szt.) }\end{array}$ \\
\hline Daewoo lublin & 1400 & 80 \\
\hline GAZ gazela & 1500 & 90 \\
\hline Citroen berlingo & 821 & 45 \\
\hline
\end{tabular}

Źródło: opracowanie własne.

Pojazdy GAZ gazela i daewoo lublin służą do codziennych planowanych dostaw pieczywa do wymienionych miejscowości. Citroen berlingo jest wykorzystywany w sytuacjach nieprzewidzianych, np. przy nieoczekiwanym zamówieniu dostawy lub w sytuacji awarii innych pojazdów.

Każdy z zatrudnionych przez piekarnię kierowców obsługuje jeden pojazd i jedną trasę. Piekarnia decyduje się na transport własny ze względu na regulacje dotyczące zasad przewozu żywności [Szubert 2014].

\section{System dystrybucji w badanym przedsiębiorstwie}

Usprawnienie systemu dystrybucji w badanym przedsiębiorstwie należy rozparzyć w dwóch płaszczyznach: kosztów transportu oraz wykorzystania ładowności pojazdów.

\section{Koszty transportu w przedsiębiorstwie}

Do określenie wielkości kosztów procesu transportu konieczne jest ustalenie odległości poszczególnych tras (A do punktu B oraz z punktu B do punktu A). W badaniach uwzględnione zostały odległości między miejscowościami oraz między punktami dostaw w każdej z nich. Obecnie funkcjonuje pięć tras (rys. 3), a do jednego punktu zbytu wyrusza jeden pojazd.
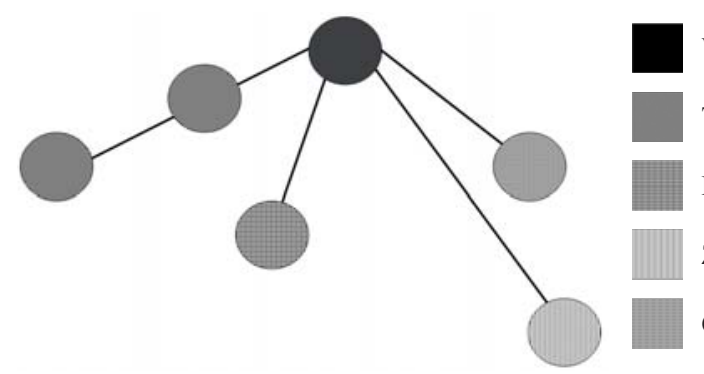

Wierzbica: $25 \mathrm{~km}, 50 \mathrm{~min}$

Trawniki-Siedliszcze: $80 \mathrm{~km}, 100 \mathrm{~min}$

Rejowiec: $60 \mathrm{~km}, 75 \mathrm{~min}$

Żmudź: 90 km, 110 min

Chełm: 50 km, $60 \mathrm{~min}$

Rysunek 3 Obowiązująca sieć dostaw badanej piekarni

Figure 3. Existing delivery network of the examined bakery

Źródło: opracowanie własne. 
Obowiązujące trasy determinują wielkość rocznych kosztów transportu w przedsiębiorstwie. Całkowity roczny koszt dystrybucji produktów przedsiębiorstwa to $163960,98 \mathrm{zl}$. Warto zauważyć, że koszt obsługi $1 \mathrm{~km}$ trasy maleje proporcjonalnie do wydłużenia odległości. Największy koszt jest w trasie przejazdów obsługujących Wierzbicę i najbliższe miejscowości, a najmniejszy na trasie Wierzbica-Żmudź (tab. 2).

Tabela 2. Koszty transportu produktów w badanym przedsiębiorstwie

Table 2. The costs of transporting products in the surveyed enterprise

\begin{tabular}{|c|c|c|c|c|c|c|c|c|c|}
\hline \multicolumn{2}{|c|}{ Wyszczególnienie } & $\begin{array}{l}\vec{N} \\
\frac{.}{0} \\
\text { Q }\end{array}$ & 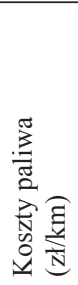 & 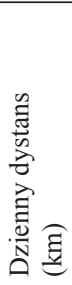 & 歎递 & 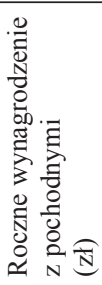 & 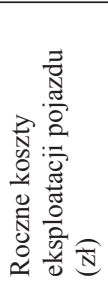 & 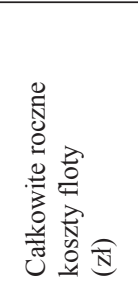 & 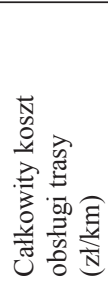 \\
\hline \multirow{5}{*}{ 萢 } & Wierzbica & $\begin{array}{l}\text { daewoo } \\
\text { lublin }\end{array}$ & 0,115 & 25 & 7225 & 14400 & 15000 & 30230,88 & 4,18 \\
\hline & $\begin{array}{c}\text { Trawniki- } \\
\text {-Siedliszcze }\end{array}$ & $\begin{array}{c}\text { GAZ } \\
\text { gazela }\end{array}$ & 0,105 & 80 & 23120 & 18000 & 15000 & 35427,60 & 1,53 \\
\hline & Rejowiec & $\begin{array}{c}\text { daewoo } \\
\text { lublin }\end{array}$ & 0,115 & 60 & 17340 & 18000 & 15000 & 34994,10 & 2,02 \\
\hline & Żmudź & $\begin{array}{c}\text { daewoo } \\
\text { lublin }\end{array}$ & 0,115 & 90 & 26010 & 14400 & 15000 & 32391,15 & 1,25 \\
\hline & Chełm & $\begin{array}{c}\text { GAZ } \\
\text { gazela }\end{array}$ & 0,105 & 50 & 14450 & 14400 & 15000 & 30917,25 & 2,14 \\
\hline \multicolumn{4}{|c|}{ Raz } & 305 & 88145 & 79200 & 75000 & 163960,98 & $\bar{x}=1,86$ \\
\hline
\end{tabular}

Źródło: opracowanie własne na podstawie danych zebranych podczas wywiadu bezpośredniego z przedstawicielem firmy.

Dotychczasowa organizacja dystrybucji trwała łącznie na wszystkich trasach $395 \mathrm{~min}$ w ciągu doby, a najdłużej (110 min) zajmuje przejazd do najbardziej oddalonej miejscowości od miejsca produkcji, tj. Żmudź (rys. 3).

\section{Wykorzystanie ladowności pojazdów floty przedsiębiorstwa}

Obecnie do dystrybucji dziennej dystrybucji pieczywa wykorzystywanych jest pięć pojazdów. Na podstawie analizy danych (tab. 3) można wskazać, że współczynnik wypełnienia każdego z nich nie jest efektywny. Najmniejsze wykorzystanie (25 i 31,25\% ładowności) jest w przypadku dystrybucji pieczywa do Żmudzi oraz w obrębie Wierzbicy i jest o około 20\% mniejsze od średniej w Polsce i 35\% mniejsze od średniej w innych krajach Unii Europejskiej łącznie [EEA 2010]. Dodatkowo warto podkreślić że analiza nie uwzględnia powrotów samochodów „na pusto”, które dodatkowo zmniejszyłyby wartość współczynnika wypełnienia pojazdów [Adra i in. 2004]. Średnia wykorzystanej ładowności pojazdów na poziomie 44,05\% potwierdza zły dobór środków transportu w przedsiębiorstwie. 
Tabela 3. Obecne wykorzystanie ładowności pojazdów floty w przedsiębiorstwie

Table 3. Current use of the fleet's load capacity in the enterprise

\begin{tabular}{|c|c|c|c|c|c|c|c|c|}
\hline \multicolumn{2}{|c|}{ Wyszczególnienie } & $\begin{array}{l}\vec{N} \\
\frac{\pi}{2} \\
\text { م }\end{array}$ & 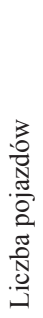 & 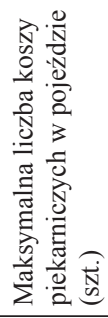 & 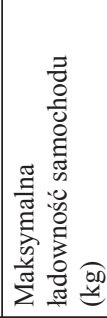 & 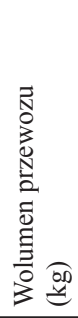 & 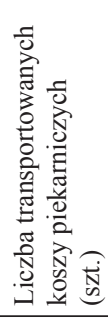 & 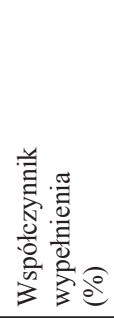 \\
\hline \multirow{5}{*}{ 胥 } & Wierzbica & $\begin{array}{c}\text { daewoo } \\
\text { lublin }\end{array}$ & 1 & 80 & 1400 & 375 & 25 & 31,25 \\
\hline & Trawniki-Siedliszcze & GAZ gazela & 1 & 90 & 1500 & 750 & 50 & 55,56 \\
\hline & Rejowiec & $\begin{array}{c}\text { daewoo } \\
\text { lublin }\end{array}$ & 1 & 80 & 1400 & 450 & 30 & 37,50 \\
\hline & Żmudź & $\begin{array}{l}\text { daewoo } \\
\text { lublin }\end{array}$ & 1 & 80 & 1400 & 300 & 20 & 25,00 \\
\hline & Chełm & GAZ gazela & 1 & 90 & 1500 & 900 & 60 & 66,67 \\
\hline \multicolumn{6}{|c|}{ Razem } & 2775 & 185 & $\bar{x}=44,05$ \\
\hline
\end{tabular}

Źródło: opracowanie własne na podstawie danych zebranych podczas wywiadu bezpośredniego z przedstawicielem firmy.

Problemy występujące w obecnym systemie dystrybucji dotyczą organizacji sieci dostaw i zarządzania dystrybucją fizyczną:

- koszt transportu na odcinku $1 \mathrm{~km} \mathrm{w}$ Wierzbicy jest średnio o połowę większy od kosztów występujących w innych trasach, co może wynikać z nieprawidłowego doboru środka transportu do tonażu i odległości,

- ładowność floty jest wykorzystana nieefektywnie, a przewozy można uznać za generujące zbędne koszty,

- utrzymywanie floty pojazdów na wypadek nieoczekiwanych zamówień powoduje zwiększenie kosztów dystrybucji,

- piekarnia wykorzystuje swoją zdolność produkcyjną w $80 \%$.

\section{Propozycja zmiany systemu dystrybucji w przedsiębiorstwie}

Sposobem na rozwiązanie problemów dystrybucji w badanej piekarni jest modyfikacja sieci dostaw, tak aby zmniejszyć liczebność floty oraz kierowców, co przełoży się na zmniejszenie kosztów ponoszonych przez przedsiębiorstwo w tym zakresie.

Pierwszym elementem jest przypisanie kilku punktów do jednego pojazdu. Biorąc pod uwagę ograniczenia wagowe i wymiarowe, możliwe jest połączenie tras w konfiguracjach przedstawionych na rysunku 4.

W przypadku proponowanej trasy w skali roku koszty całkowite obsługi floty wyniosą 104 262,76 zł, a średni koszt całkowity obsługi $1 \mathrm{~km}-1,62 \mathrm{zł}$ (tab. 4). Dzienna odległość pokonywana przez pojazdy floty to $222,5 \mathrm{~km}$. Dodatkowo warto wskazać, że łączny dobowy czas przejazdu floty to $280 \mathrm{~min}$ (rys. 4). 


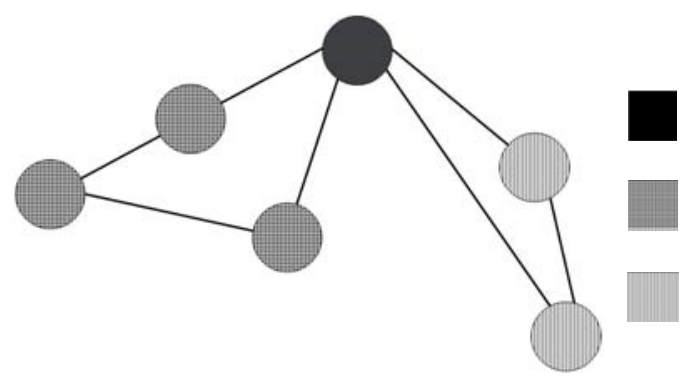

Wierzbica: $25 \mathrm{~km}, 50 \mathrm{~min}$

Wierzbica-Rejowiec-Trawniki-

-Siedliszcze-Wierzbica: $100 \mathrm{~km}, 120 \mathrm{~min}$

Wierzbica-Chełm-Żmudź-Wierzbica-

-Żmudź: $97,5 \mathrm{~km}, 110 \mathrm{~min}$

Rysunek 4. Proponowane trasy dystrybucji pieczywa

Figure 4. Suggested bread distribution routes

Źródło: opracowanie własne.

Tabela 4. Koszty transportu dla proponowanej trasy dystrybucji produktów w przedsiębiorstwie

Table 4. Transport costs for the proposed product distribution route in the company

\begin{tabular}{|c|c|c|c|c|c|c|c|c|}
\hline & Wyszczególnienie & $\begin{array}{l}\frac{\vec{N}}{0} \\
\frac{\pi}{2}\end{array}$ & 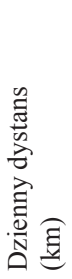 & 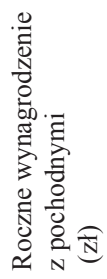 & 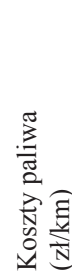 & 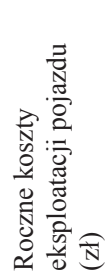 & 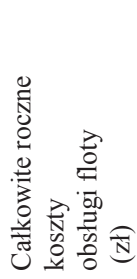 & 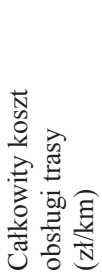 \\
\hline & Wierzbica & $\begin{array}{l}\text { citroen } \\
\text { berlingo }\end{array}$ & 25 & 14400 & 0,065 & 15000 & 29869,625 & 4,13 \\
\hline$\stackrel{\mathscr{7}}{\overparen{a}}$ & $\begin{array}{c}\text { Rejowiec-Trawniki- } \\
\text {-Siedliszcze }\end{array}$ & GAZ gazela & 100 & 19200 & 0,105 & 15000 & 37234,5 & 1,29 \\
\hline & Chełm-Żmudź & GAZ gazela & 97,5 & 19200 & 0,105 & 15000 & 37158,638 & 1,32 \\
\hline & Razem & 222,5 & & 52800 & $x$ & 45000 & 104262,76 & 1,62 \\
\hline
\end{tabular}

Źródło: opracowanie własne.

Citroen berlingo jako najmniejszy samochód floty jest przydzielony do dystrybucji produktów na terenie Wierzbicy i najbliższych okolic. Jego wymiary oraz maksymalna ładowność wystarczają do obsłużenia tonażu $375 \mathrm{~kg}$. Przy założeniach dotyczących minimalnego współczynnika wypełnienia samochodów $(80 \%)$ proponowanym środkiem transportu trasach poza Wierzbicę jest pojazd GAZ gazela, który jednocześnie umożliwia ewentualne zwiększenie tonażu i wolumenu ładunku w wypadku zmiany wielkości zamówienia (tab. 5).

Po wprowadzeniu zmian organizacji dystrybucji w przedsiębiorstwie przy przyjętych założeniach całkowite koszty transportu produktów zmniejszyłyby się o 36,41\%. Dodatkowo trasy mogłyby być obsługiwane przez dwa samochody mniej. W tych, które byłyby wykorzystywane, wartość współczynnika wypełnienia byłaby większa o 38 p.p. (tab. 6). 
Tabela 5. Wykorzystanie ładowności pojazdów floty w przedsiębiorstwie po wprowadzeniu zmian tras

Table 5. Utilizing the load capacity of fleet vehicles in the company after making changes to the routes

\begin{tabular}{|c|c|c|c|c|c|c|c|c|}
\hline & Wyszczególnienie & $\begin{array}{l}\vec{J} \\
\frac{\sqrt{0}}{0} \\
\stackrel{0}{0}\end{array}$ & 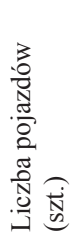 & 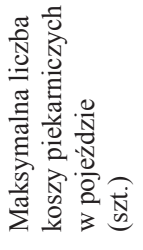 & 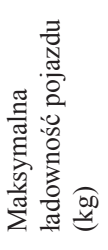 & 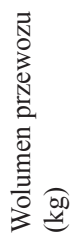 & 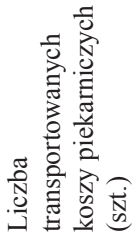 & 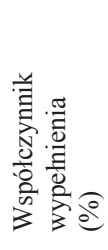 \\
\hline & Wierzbica & $\begin{array}{l}\text { citroen } \\
\text { berlingo }\end{array}$ & 1 & 45 & 821 & 375 & 25 & 56 \\
\hline 苞 & $\begin{array}{c}\text { Rejowiec- } \\
\text {-Trawniki-Siedliszcze }\end{array}$ & $\begin{array}{l}\text { GAZ } \\
\text { gazela }\end{array}$ & 1 & 90 & 1500 & 1200 & 80 & 89 \\
\hline & Chełm-Żmudź & $\begin{array}{l}\text { GAZ } \\
\text { gazela }\end{array}$ & 1 & 90 & 1500 & 1200 & 80 & 89 \\
\hline & Razem & & 3 & 225 & 3821 & 2775 & 185 & 82 \\
\hline
\end{tabular}

Źródło: opracowanie własne.

Tabela 6. Analiza porównawcza rocznych wyników obecnej i proponowanej organizacji dystrybucji w badanej piekarni

Table 6. Comparative analysis of the annual results of the current and proposed distribution organization in the bakery under study

\begin{tabular}{|l|c|c|c|}
\hline Wyszczególnienie & $\begin{array}{c}\text { Obecna organizacja } \\
\text { dystrybucji }\end{array}$ & $\begin{array}{c}\text { Proponowana organizacja } \\
\text { dystrybucji }\end{array}$ & Różnica \\
\hline Koszty całkowite (zł) & 163960,98 & 104262,76 & $36,41 \%$ \\
\hline Koszt przejazdu 1 km (zł) & 1,86 & 1,62 & $12,83 \%$ \\
\hline Czas przejazdu (min) & 395 & 280 & $29,11 \%$ \\
\hline Liczba wykorzystanych pojazdów (szt.) & 5 & 3 & 2 \\
\hline Współczynnik wypełnienia & $44,05 \%$ & $82,22 \%$ & 38 p.p. \\
\hline
\end{tabular}

Źródło: opracowanie własne.

\section{Podsumowanie}

Celem głównym badań było wskazanie możliwości usprawnienia systemu dystrybucji pieczywa wytwarzanego w piekarni zlokalizowanej w Wierzbicy. Cel pracy został osiągnięty poprzez studia literatury oraz analizę przyjętych w pracy wskaźników. Zaproponowano przekształcenie obecnej sieci dostaw, dzięki któremu możliwe jest ograniczenie kosztów transportu, osiągnięcie większej wartości współczynnika wypełnienia floty oraz 
skrócenie czasu przejazdu. Tym samym zweryfikowano pozytywnie dwie postawione w artykule hipotezy.

Wydatki ponoszone przez Piekarnię Wierzbica na utrzymanie obecnych tras mogłyby zasilić środki pieniężne na zwiększenie produkcji do poziomu maksymalnej zdolności produkcyjnej. Dzięki obecnej konfiguracji sieci dostaw koszty transportu ulegną zmniejszeniu.

Warto podkreślić, że opracowanie nie wyczerpuje zagadnień związanych z zarządzaniem systemem dystrybucji i zasadne są dalsze badania w zakresie poruszonej tematyki. Należy również pamiętać, że w każdym przedsiębiorstwie proponowane rozwiązania mogą się od siebie różnić ze względu na charakter oferowanych produktów i zawierane kontakty partnerskie z pośrednikami. Zazwyczaj usprawnianie procesu dystrybucji dotyczy jednak wspomnianej struktury, czyli kanałów dystrybucji, a także sposobu udostępniania produktów na rynku. Dominującą rolę w systemie dystrybucji oraz w działalności całego przedsiębiorstwa odgrywają procesy transportowe, co potęguje potrzebę usprawniania tego procesu i wprowadzania zamian w jego zakresie. Istotny jest zatem rozsądny wybór sposobu transportu - począwszy od wyboru gałęzi transportu, przez środki transportu po obszar działalności.

\section{Literatura}

Adra N., Michaux J.L., Andre M., 2004: Analysis of the load factor and the empty running rate for road transport. Artemis - assessment and reliability of transport emission models and inventory systems. Rapport de recherche, INRETS/LTE - Laboratoire Transport et Environnement, Paris.

Baran J., Maciejczak M., Pietrzak M., Rokicki T., Wicki L., 2008: Logistyka. Wybrane zagadnienia, Wydawnictwo SGGW, Warszawa.

Baran J., Wicki L., 2011: Systemy logistyczne w funkcjonowaniu przedsiębiorstw przetwórstwa rolno-spożywczego. Raport z I etapu badań, Wydział Nauk Ekonomicznych, SGGW w Warszawie [manuskrypt].

Bębenek A., 2015: Rynek piekarniczy w Polsce, Piekarstwo 5, 8-13.

Bendkowski J., Pietrucha-Pacut M., 2003: Podstawy logistyki w dystrybucji, Wydawnictwo Politechniki Śląskiej, Gliwice.

Blasioli A., 2011: Market Survey on the Cost of the Logistic Distribution, praca magisterska, University of Bologna, Bologna [manuskrypt].

Bortolini M., Faccio M., Ferrari E., Gamberi M., Pilati F., 2016: Fresh food sustainable distribution: cost, delivery time and carbon footprint three-objective optimization, Journal of Food Engineering 174, 56-67.

Ejsmont P., 2015: Pieczywo w sieci, Piekarstwo 4, 62-63.

European Environment Agency, 2010: Load factors for freight transport, [źródło elektroniczne] https://www.eea.europa.eu/data-and-maps/indicators/load-factors-for-freight-transport/ load-factors-for-freight-transport-1 [dostęp: 02.02.2018].

Ferrarezi A.C., Olbrich dos Santos K., Monteiro M., 2013: Consumer interpretation of ready to drink orange juice and nectar labelling, Food Science Technology 48, 1296-1302. doi: 10.1111/ijfs. 12090

Ficoń K., 2001: Procesy logistyczne w przedsiębiorstwie, Impuls Plus Consulting, Gdynia. 
Górecka A., Rokicki T., 2014: The significance of transportation in agribusiness companies, [w:] Carpathian Logistics Congress - Congress Proceedings, Ostrava.

Gorzelany-Dziadkowiec M. 2012: Wykorzystanie kluczowych czynników sukcesu w analizie strategicznej na przykładzie branży piekarniczo-cukierniczej, [w:] Analiza strategiczna wybranych branż przemysłu rolno-spożywczego w Polsce, K. Firlej (red.), Wydawnictwo Uniwersytetu Ekonomicznego w Krakowie, Kraków.

GUS 2013: Rocznik statystyczny rolnictwa 2012, Warszawa.

GUS 2018: Rocznik statystyczny rolnictwa 2017, Warszawa.

Kaczmarczyk T., 2012: Koszty logistyczne w wybranym przedsiębiorstwie produkcyjno-handlowym, Logistyka 3 [CD].

Kadłubek M., 2012: Zarządzanie procesami dystrybucji w przedsiębiorstwie, cz. 2, Logistyka 5, 490-496 [CD].

Matuszewski A., Ratajczak P., 2003: Logistyka zaopatrzenia i dystrybucji wyrobów o krótkim okresie trwałości, Logistyka 4, 22-23.

Pacana A., Liberko I., Bednárová L., Wołoszyn P, 2014: Analiza i propozycje doskonalenia kanałów dystrybucji w Piekarni Rabinówka, Logistyka 6 [CD].

Rong A., Akkerman R., Grunow M., 2011: An optimization approach for managing fresh food quality throughout the supply chain, International Journal of Production Economics 131 (1): 421-429. doi: 10.1016/j.ijpe.2009.11.026

Szubert A., 2014: Znaczenie i specyfika transportu w branży spożywczej, [źródło elektroniczne] http://www.trans.eu/pl/aktualnosci/znaczenie-i-specyfika-transportu-w-branzy-spozywczej [dostęp: 02.02.2018].

Urbanyi-Popiołek I. (red.), 2013: Ekonomiczne i organizacyjne aspekty transportu, Wydawnictwo Uczelniane Wyższej Szkoły Gospodarki w Bydgoszczy, Bydgoszcz.

Żurawska A., Kulińska E., 2015: Koszty logistyki dystrybucji - relacja: decyzja - ryzyko - koszt, Logistyka $6[\mathrm{CD}]$.

Adres do korespondencji:

dr Aleksandra Górecka

(https://orcid.org/ 0000-0002-2679-561X)

Szkoła Główna Gospodarstwa Wiejskiego w Warszawie Wydział Nauk Ekonomicznych

Katedra Logistyki

ul. Nowoursynowska 166, 02-787 Warszawa

tel.: (+48) 225934247

e-mail: aleksandra_gorecka@sggw.pl 



\title{
Ekonomika i Organizacja Logistyki \\ 3 (3), 2018, 51-59
}

DOI: 10.22630/EIOL.2018.3.3.21

\author{
Bogdan Klepacki ${ }^{1}$, Malgorzata Koper ${ }^{2}$ \\ ${ }^{1}$ Szkoła Główna Gospodarstwa Wiejskiego w Warszawie \\ 2 ACSB Wsparcie Małego Biznesu Daniel Wieteska w Raszynie
}

\section{Bezpieczeństwo w ruchu drogowym w opiniach jego uczestników}

\section{Road safety in the opinion of its participants}

\begin{abstract}
Synopsis. W opracowaniu przedstawiono problematykę skali i przyczyn wypadków drogowych w Polsce. Rozpoznano także opinie użytkowników na temat stanu dróg, a także konieczności ich poprawy. Stwierdzono, że bezpośredni wpływ stanu infrastruktury na liczbę wypadków był niewielki. To nierozwaga i brawura uczestników ruchu w głównej mierze przyczyniają się do złego stanu bezpieczeństwa, z jakim mamy do czynienia w Polsce.
\end{abstract}

Słowa kluczowe: infrastruktura drogowa, wypadki drogowe, bezpieczeństwo na drogach

\begin{abstract}
The study presents the problem of the scale and causes of road accidents in Poland. Users' opinions on the condition of roads as well as the need to improve them were also recognized. It was found that the direct impact of the condition of the infrastructure on the number of accidents was small, the imprudence and bravado of traffic participants largely contributes to the poor security situation we face in Poland.
\end{abstract}

Key words: road infrastructure, road accidents, road safety

\section{Wstęp}

W Polsce w 2017 roku w wypadkach drogowych zginęło 2831 osób, a 11103 zostało ciężko rannych [KRBRD 2018]. W stosunku do najtragiczniejszego w dekadzie 2008-2017 liczba wypadków śmiertelnych zmniejszyła się o 47,9\%, a wypadków z ofiarami ciężko rannymi o 30,8\%. Można więc uznać, że sytuacja uległa poprawie, choć nadal liczby te są znaczące. Dla porównania na milion mieszkańców w 2017 roku w Polsce było 75 ofiar śmiertelnych (średnio w UE 49 osób), a w Szwecji 25, Wielkiej Brytanii 27, Holandii 31, a Danii 32 osoby (dla kontrastu - w Rumunii wskaźnik ten wynosił 98, a Bułgarii 96). Sytuacja poprawia się w całej Unii Europejskiej, bowiem w latach 2008-2017 nie było żadnego kraju, w którym liczba wypadków śmiertelnych w stosunku do liczby mieszkańców by się nie zmniejszyła. Najbardziej bezpieczeństwo na drogach 
poprawiło się w Estonii (o 64\% mniej ofiar śmiertelnych) i na Litwie oraz w Danii (po $57 \%$ ). Polska znalazła się w grupie na poziomie średnim (48\%), a najmniejszy był postęp tam, gdzie już wcześniej osiągnięto dobre wyniki, to jest we Francji (21\%) i w Holandii (24\%) [KRBRD 2018].

Bezpieczeństwo drogowe jest elementem bezpieczeństwa publicznego, stąd przypisuje mu się duże znaczenie. Ogólnie za najistotniejsze elementy wpływające na bezpieczeństwo w ruchu drogowym uznaje się infrastrukturę, środki transportu oraz użytkowników, czyli kierowców i pieszych. Z roku na rok liczba użytkowników dróg rośnie, a zapewnienie bezpieczeństwa jest jednym z najważniejszych i najtrudniejszych wyzwań stojących przed państwem. Budowa nowych obiektów infrastruktury drogowej i modernizacja obecnych powinny być priorytetem dla rządzących.

Celem badań było poznanie opinii użytkowników infrastruktury drogowej dotyczących stanu bezpieczeństwa w ruchu drogowym. Zakres czasowy badań empirycznych to lata 2010-2017. W celu pozyskania opinii użytkowników ruchu drogowego przeprowadzono badania ankietowe na grupie celowo wybranych 150 osób w sierpniu i we wrześniu 2017 roku.

\section{Zagrożenia na drodze oraz przyczyny wypadków drogowych}

Przyczyn powstawania i skutków wypadków na drodze jest wiele, ale najważniejszym czynnikiem wpływającym na bezpieczeństwo w ruchu drogowym jest człowiek. Do bezpośrednich przyczyn wypadków leżących po stronie człowieka można zaliczyć: nadmierną prędkość, nietrzeźwość, nieprzestrzeganie przepisów drogowych, nieprawidłowe manewry w czasie jazdy, zmęczenie, zaśnięcie za kierownicą samochodu, niezachowanie odpowiedniej odległości w czasie jazdy pomiędzy pojazdami, nieustępowanie pierwszeństwa pieszym, usterki i wady pojazdów, a także nieprzestrzeganie przez pieszych przepisów ruchu drogowego. Najwięcej wypadków wynika z nieprzestrzegania pierwszeństwa przejazdu oraz przekraczania dozwolonych limitów prędkości.

Drugą grupę przyczyn stanowią te, które nie są zależne od kierowcy, takie jak: zły stan infrastruktury drogowej ${ }^{1}$, nieprawidłowe oznakowanie występujących na drodze robót drogowym, nieprawidłowe oznakowanie dróg i niewłaściwa sygnalizacja świetlna, złe zarządzanie ruchem drogowym, niespodziewane pojawienie się zwierząt na drodze oraz niekorzystne warunki atmosferyczne. W 2017 roku aż 86,6\% wypadków spowodowali kierowcy, z winy pieszych doszło do $7,3 \%$ zdarzeń, a z winy pasażera do $0,4 \%$. Z innych przyczyn zostało spowodowanych 4,7\% ogółu wypadków [KGP 2018]. Z winy kierującego zginęło 73,9\%, a rannych było 87,1\%. Najczęstszą przyczyną wypadków drogowych było nieprzestrzeganie pierwszeństwa przejazdu (26,2\%), niedostosowanie prędkości do warunków ruchu $(24,1 \%)$ oraz niezachowanie ostrożności wobec pieszego $(12,0 \%)$.

Najczęstszą przyczyną wypadków z winy pieszych było [KGP 2018]:

- wejście na jezdnię bezpośrednio przed jadącym pojazdem - 49,8\% zdarzeń,

- przekraczanie jezdni w miejscu niedozwolonym -12,2\%,

\footnotetext{
${ }^{1}$ Szerzej pojęcie i stan infrastruktury przedstawiono w opracowaniu Klepackiego i Koper [2017], a jej znaczenie dla bezpieczeństwa ruchu w opracowaniu Klepackiego i Koper [2018].
} 
- wejście na jezdnię zza pojazdu, przeszkody - 11,3\%,

- wejście na jezdnię przy czerwonym świetle - 10,4\% wypadków.

Infrastruktura drogowa nie jest najważniejszym, ale istotną przyczyną wypadków. W 2017 roku niewłaściwy stan jezdni był przyczyną 70 wypadków, do 2 doszło w wyniku nieprawidłowego zabezpieczenia robót drogowych, czyli elementom infrastruktury można przypisać 72 zdarzenia $(0,22 \%$ ich całości). Wady techniczne pojazdu były przyczyną 40, czyli 0,14\% wypadków (najczęstsze usterki to braki w oświetleniu i ogumieniu lub usterki układu hamulcowego bądź kierowniczego). Zginęło w nich 6 osób, a rany odniosło 49 osób Ważnymi przyczynami było też zmęczenie i zaśniecie kierowcy (569, czyli 2,0\%), czy inne przyczyny (4,8\% wypadków) [KGP 2018].

\section{Skala wypadków drogowych w Polsce}

Wypadków drogowych w Polsce było w 2017 roku prawie 33 tys., a w 2007 roku prawie 50 tys., czyli miał miejsce spadek o 39,9\% (rys. 1). W badanych latach najwięcej wypadków było w 2007 roku, a najmniej w 2017 roku.

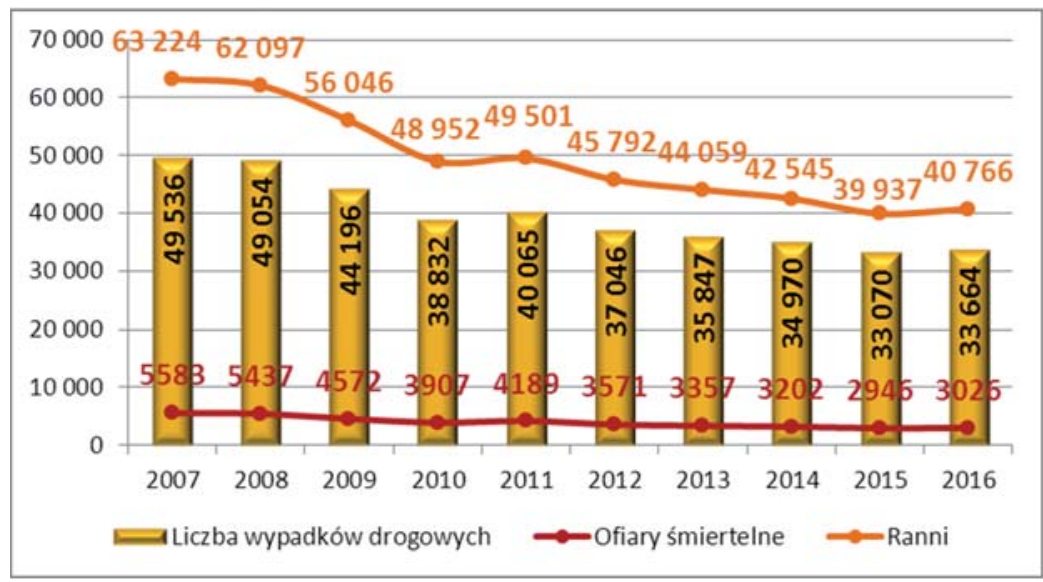

Rysunek 1. Liczba wypadków i ich ofiar w latach 2007-2017

Figure 1. The number of accidents and their victims in 2007-2017

Źródło: [MSWiA 2018].

W 2017 roku najwięcej, bo aż 73,9\%, wypadków drogowych miało miejsce na jezdni. W tych wypadkach zginęło 2198 osób, co stanowiło 77,6\% wszystkich ofiar śmiertelnych wypadków drogowych w tymże roku [KGP 2018].

Najwięcej wypadków drogowych w 2017 roku było w październiku, czerwcu i lipcu, $\mathrm{w}$ piątki. Wzmożony ruch na drogach $\mathrm{w}$ tych miesiącach jest związany $\mathrm{z}$ wyjazdami ludzi, podróżami w czasie wakacji oraz przerwy świątecznej w miesiącu grudzień. Łącznie w ciągu tych trzech miesięcy spowodowano 9361 wypadków, co stanowiło 28,4\% wszystkich wypadków w 2015 roku. Zimą czynnikiem, który w dużej mierze przyczynia się do takich wyników, są złe warunki atmosferyczne. 
Prawie 70\% wypadków w 2017 roku zostało spowodowanych w ciągu dnia (69,9\%), w godzinach 14:00-16:00, gdyż wówczas na drogach panuje największy ruch. Większość wypadków miała miejsce przy dobrych warunkach atmosferycznych, jednak do wypadków dochodziło także wówczas gdy było pochmurno, podczas opadów śniegu, mgły i silnych wiatrów. Oślepiające słońce także stwarza często zagrożenie na drodze.

Większość wypadków w 2017 roku miała miejsce na terenach zabudowanych (71\%), jednak więcej ofiar śmiertelnych odnotowano na terenach niezabudowanych $(56,3 \%)$. Tereny te charakteryzują się mniejszym natężeniem ruchu, co pozwala na osiąganie znacznych prędkości, a więc wzrasta prawdopodobieństwo wypadków śmiertelnych.

Najwięcej wypadków drogowych spowodowanych było przez kierowców poruszających się samochodami osobowymi (66,6\% wszystkich wypadków drogowych). W tych wypadkach śmierć poniosło 1506 osoby $(72,0 \%$ ofiar śmiertelnych w wypadkach drogowych w 2017 r.).

Co roku najwięcej wypadków drogowych odnotowywano w województwach: łódzkim, małopolskim, mazowieckim (z Warszawą), śląskim i wielkopolskim - w 2017 roku stanowiły ponad $45,6 \%$ wszystkich wypadków. W województwach małopolskim i śląskim istniała największa gęstość dróg na $100 \mathrm{~km}^{2}$, co wpływa w dużym stopniu na ryzyko wystąpienia wypadku drogowego. W przypadku województwa mazowieckiego przyczyną tak dużej liczby wypadków jest to, że województwo to osiągnęło jeden z najwyższych wskaźników motoryzacji.

Szacunkowo koszt wszystkich wypadków drogowych oraz kolizji w Polsce w 2015 roku wyniósł około 48,2 mld zł, co stanowiło około 3\% PKB [Jaździk-Osmólska 2016]. Do kategorii kosztów zaliczają się straty produkcji tytułem śmierci bądź też niemożności wykonywania pracy zarobkowej, koszty administracyjne, koszty hospitalizacji, koszt uszkodzonego mienia. Są to szacunkowe dane, gdyż nie jest możliwa wycena wszystkich strat dla społeczeństwa oraz gospodarki związanych z wypadkami drogowymi.

Najwyższa Izba Kontroli uważa, że w Polsce nie dojdzie do radykalnego podwyższenia poziomu bezpieczeństwa na drogach, budowy dróg dwujezdniowych, poszerzania dróg jednojezdniowych o pobocza i pasy bezpiecznego wyprzedzania, wyodrębniania pasów i sygnalizacji świetlnej do bezpiecznego skrętu w lewo, rozwiązań chroniących pieszych (takich jak: chodniki, kładki, przejścia podziemne, zamknięte dla ruchu place i deptaki, sygnalizacja świetlna w miejscach natężenia ruchu, wyodrębnionych ścieżek rowerowych), rozwoju komunikacji miejskiej oraz „,bez promowania właściwych zachowań przez uczestników ruchu drogowego, w tym poszanowania się przez kierowców, pieszych i rowerzystów, a także świadomości konsekwencji naruszenia przepisów [NIK 2016].

\section{Bezpieczeństwo ruchu drogowego w opiniach jego użytkowników}

W celu uzyskania opinii użytkowników na temat stanu dróg i bezpieczeństwa ruchu dróg zostało przeprowadzone badanie ankietowe. W badaniu wzięło udział 150 ankietowanych, z czego 55 osób to byli mężczyźni. Około $81 \%$ osób posiadało wyższe wykształcenie, $18 \%$ wykształcenie średnie. Ponad $90 \%$ respondentów to osoby w wieku 18-39 lat. Spośród ankietowanych 129 osób miało pojazd, w tym 74,4\% (112) samochód osobowy, a 2\% motocykl. Wśród pojazdów najwięcej było o 6-11-letnim 
(36\%) oraz 12-20-letnim okresie użytkowania (27\%). Aż 7\% stanowiły pojazdy ponad 20-letnie (nawet 3\% ponad 25 lat).

Spośród ankietowanych 9,3\% osób miało w ciągu ostatnich 5 lat wypadek drogowy. Najczęściej przyczyną było wymuszenie pierwszeństwa przejazdu, następnie niezachowanie odpowiedniej odległości pomiędzy samochodami, nadmierna prędkość, w tym niewyhamowanie na światłach, zagapienie się w czasie jazdy, źle oznakowane przejście dla pieszych oraz brak zasygnalizowania przez kierowcę skrętu.

Ponad 30\% ankietowanych uważało, że liczba dróg w Polsce jest na odpowiednim poziomie, a 37,8\% stwierdziło, że jest ich za mało. Zdania były podzielone - część respondentów uznawała, że potrzebna jest budowa nowych sieci dróg, inna wskazywała na obecny stan liczbowy jako zadowalający.

Nikt z respondentów nie uznał poziomu technicznego dróg za bardzo wysoki (rys. 2). Aż 56,7\% ankietowanych określiło go jako zły, w tym 18,7 \% zdecydowanie zły. Zaledwie $8,7 \%$ przyznało ocenę dobrą, a 34,7\% ocenę średnią. Oznacza to, że stan dróg jest akceptowalny przez użytkowników, ale wszelkiego rodzaju zabiegi modernizacyjne i remontowe poprawią tę ocenę.

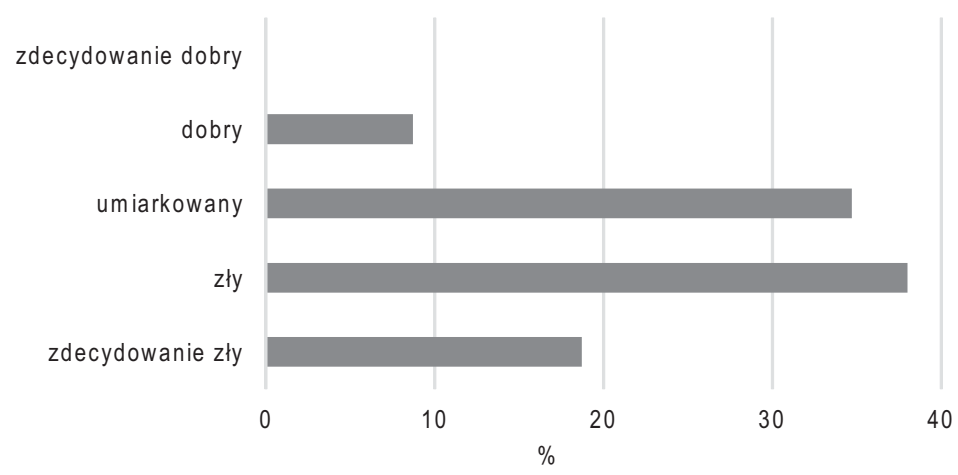

Rysunek 2. Ocena sytuacji pod względem stanu technicznego dróg

Figure 2. Assessment of the situation in terms of technical condition of roads

Źródło: badania własne.

Najgorzej oceniano drogi gminne, aż 64,7\% ankietowanych uważało, że właśnie tam wymagane są największe inwestycje. Jest to kategoria dróg, których w Polsce jest najwięcej i są one najczęściej użytkowane. Ponad 23\% osób uważało, że to drogi powiatowe charakteryzowały się najgorszym stanem nawierzchni, a 7,3\%, że drogi wojewódzkie. Wśród ankietowanych zaledwie 4,7\% oceniło stan dróg krajowych jako zły.

Około 57\% osób uważało, że stan techniczny polskich dróg jest zły, stąd też na pytanie dotyczące wymaganych działań aż 90\% ankietowanych wskazało na poprawę stanu nawierzchni (rys. 3). Na drugim miejscu wskazywano na potrzebę budowy skrzyżowań bezkolizyjnych (57,3\%). Znaki drogowe oraz sygnalizacja świetlna jest problemem dla użytkowników ruchu i w tym zakresie również wymagane są działania. Budowa kładek dla pieszych była dla 24,7\% jednym z głównych elementów poprawiających bezpieczeństwo, a zabezpieczenia na przejazdach kolejowych dla 26,7\%. Jedynie 4,7\% ankietowanych wskazało, że w Polsce należałoby rozbudować sieć fotoradarów. W założeniu jej celem jest 


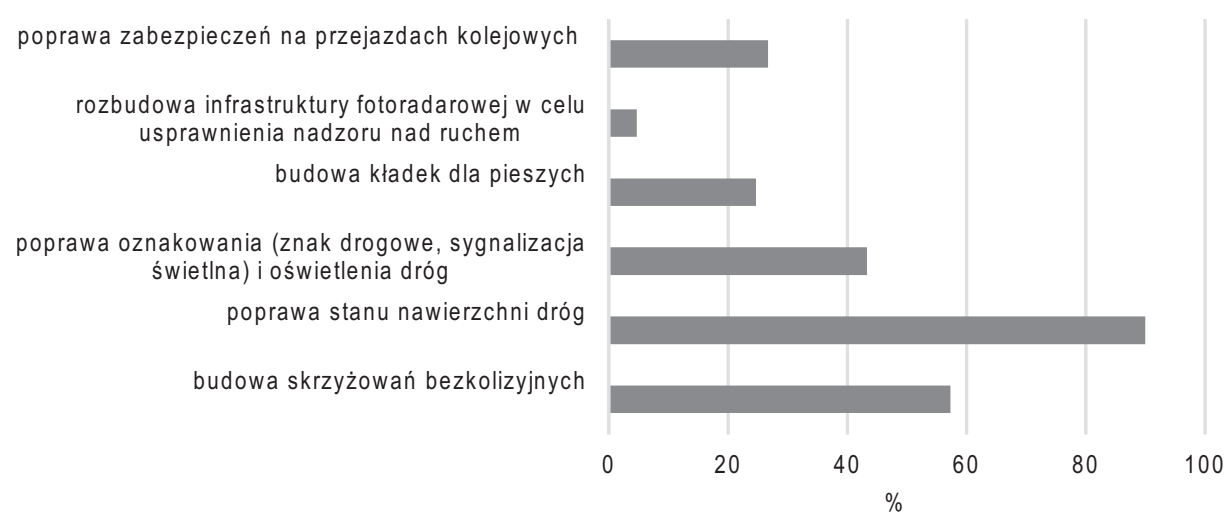

Rysunek 3. Najpilniejsze prace w zakresie poprawy infrastruktury drogowej

Figure 3. The most urgent work in the field of road infrastructure improvement

Źródło: badania własne.

zwiększenie bezpieczeństwa w ruchu drogowym, jednak w społeczeństwie postrzegana jest negatywnie. Kojarzy się kierowcom głównie z mandatami i punktami karnymi.

Do najważniejszych przyczyn niewystarczającego poziomu bezpieczeństwa w ruchu drogowym (rys. 4) respondenci (mogli wybrać 3 najważniejsze) zaliczyli zły stan dróg (74,7\% ankietowanych), wiek i zły stan techniczny pojazdów $(73,3 \%)$ oraz jazdę pod wpływem alkoholu (43,3\%). Potrzebna jest poprawa oznakowania drogowego - znaków drogowych i sygnalizacji świetlnej, których obecny stan (według 23,3\% ankietowanych) w znacznym stopniu wpływa negatywnie na bezpieczeństwo. Dotychczasowe kampanie społeczne za czynnik poprawy bezpieczeństwa na drogach uznało zaledwie $4 \%$ respondentów.

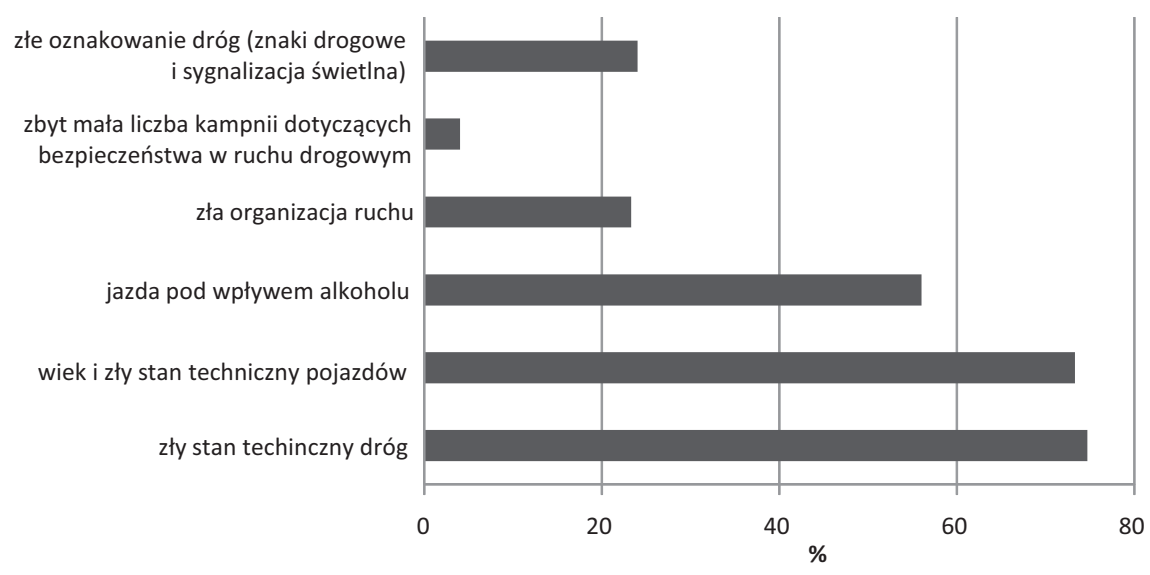

Rysunek 4. Przyczyny niskiego poziomu bezpieczeństwa w ruchu drogowym Figure 4. Reasons for a low level of road safety

Źródło: badania własne. 
Na rysunku 5 przedstawiono opinie respondentów na temat działań niezbędnych dla poprawy bezpieczeństwa na drogach. W celu poprawy bezpieczeństwa $\mathrm{W}$ ruchu drogowym budowa nowej i modernizacja obecnej infrastruktury drogowej powinna być priorytetem dla państwa (taką odpowiedź wskazało ponad 90\% ankietowanych) oraz usprawnienie systemu zarządzania ruchem drogowym (ponad 60\%). Za ważne uznano szkolenia i edukację prowadzone zarówno przez władze, jak i różne jednostki zajmujące się zapewnieniem bezpieczeństwa na drogach. Relatywnie małe znaczenie przypisywano wzrostowi aktywności policji, która bardziej niż z funkcjami zapobiegawczą oraz profilaktyczną, jest kojarzona (tak jak w przypadku fotoradarów) z działaniami represyjnymi.

Prawie 50\% ankietowanych uważało, że infrastruktura w Polsce na tle innych krajów Unii Europejskiej jest na poziomie umiarkowanym (rys. 6). Jedynie 10\% respondentów oceniło ją jako dobrą, a ponad 40\% uznało jej stan za zły lub zdecydowanie zły.

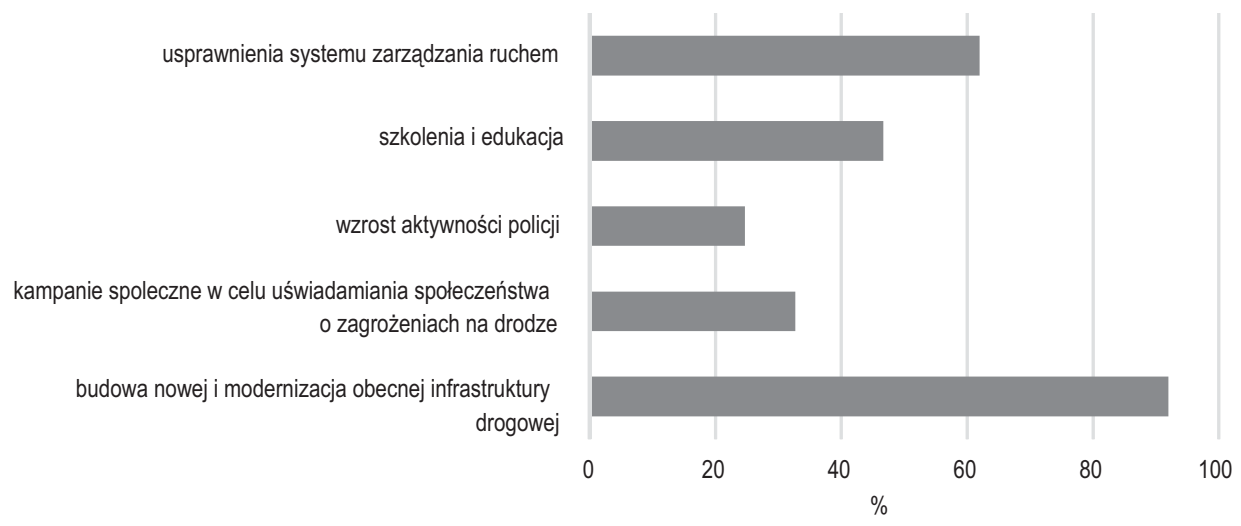

Rysunek 5. Najważniejsze działania konieczne dla poprawy bezpieczeństwa ruchu drogowego Figure 5. The most important activities necessary to improve road safety

Źródło: badania własne.

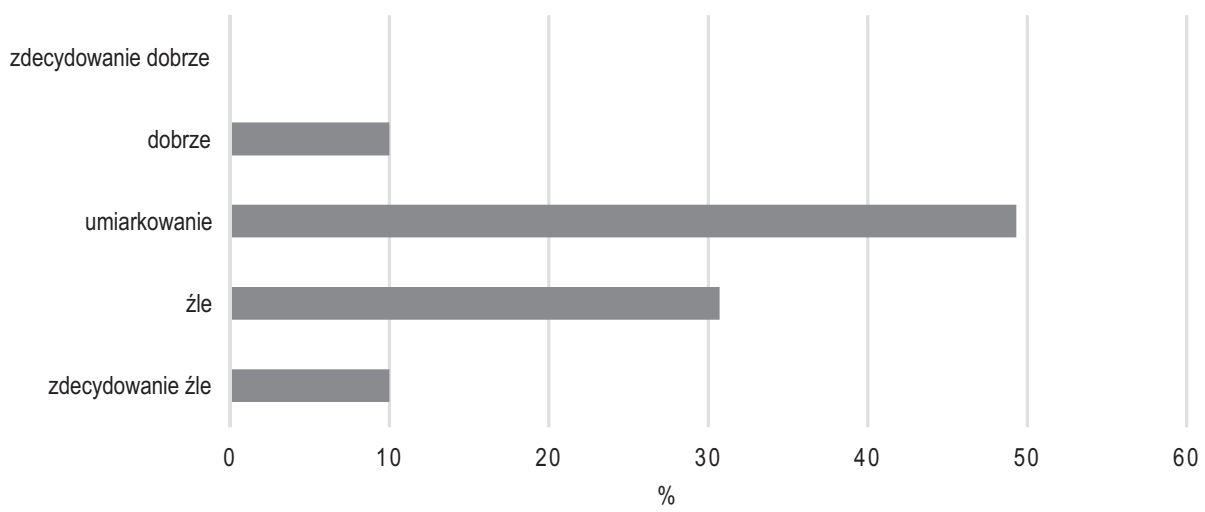

Rysunek 6. Ocena stanu infrastruktury drogowej w Polsce na tle krajów Unii Europejskiej

Figure 6. Assessment of the condition of road infrastructure in Poland against the background of European Union countries

Źródło: badania własne. 


\section{Wnioski}

1. Polska plasuje się w czołówce państw w Unii Europejskiej pod względem liczby ofiar śmiertelnych i rannych w wypadkach drogowych powodowanych przez kierowców, zwłaszcza w województwach o najlepszej infrastrukturze, szczególnie w miesiącach letnich. Głównymi przyczynami wypadków było nieustąpienie pierwszeństwa przejazdu, niedostosowanie prędkości do warunków ruchu, a także nieustąpienie pierwszeństwa pieszemu na przejściu dla pieszych.

2. Z powodu złego stanu nawierzchni w Polsce w 2017 roku miało miejsce tylko/aż 70 wypadków. Prawie połowa dróg krajowych wymaga remontu. Wyniki badań potwierdzają negatywną często ich ocenę przez użytkowników ruchu oraz wskazują, że konieczne są remonty istniejących i budowa nowych, dobrze oznakowanych drogi, stosowanie barier oddzielających ruch drogowy od pieszo-rowerowego, skrzyżowania bezkolizyjne, budowa kładek dla pieszych itp.

3. Bezpośredni wpływ stanu infrastruktury na liczbę wypadków jest niewielki, gdyż to nierozwaga i brawura uczestników ruchu w głównej mierze przyczyniają się do złego stanu bezpieczeństwa, z jakim mamy do czynienia w Polsce. Zachowania ludzkie ciężko jest jednak zmienić, kampanie społeczne na temat zagrożeń na drodze oraz ich skutków w niewielkim stopniu oddziałują na społeczeństwo. Pomimo to państwo powinno prowadzić akcję edukacji użytkowników ruchu, ale przede wszystkim podejmować takie działania, na jakie ma wpływ, czyli związane z poprawą infrastruktury drogowej.

\section{Literatura}

Jaździk-Osmólska A., 2016: Wycena kosztów wypadków i kolizji drogowych na sieci dróg w Polsce na koniec roku 2015, z wyodrębnieniem średnich kosztów społeczno-ekonomicznych wypadków na transeuropejskiej sieci transportowej, Krajowa Rada Bezpieczeństwa Ruchu Drogowego, Warszawa, [źródło elektroniczne] http://www.krbrd.gov.pl/files/file_ add/download/393_wycena-kosztow-wypadkow-i-kolizji-drogowych-2015.pdf [dostęp: 20.05.2017].

Klepacki B., Koper M., 2017: Stan i kierunki rozwoju infrastruktury drogowej w Polsce, Zeszyty Naukowe SGGW w Warszawie, Ekonomika i Organizacja Logistyki 2 (4), 5-19.

Klepacki B., Koper M., 2018: Miejsce infrastruktury w kształtowaniu bezpieczeństwa w ruchu drogowym, Zeszyty Naukowe SGGW w Warszawie, Ekonomika i Organizacja Logistyki $3(1), 39-49$.

Komenda Główna Policji, 2017: Wypadki drogowe w Polsce w 2017 roku. Biuro Ruchu Drogowego Zespół Profilaktyki i Analiz, Warszawa, [źródło elektroniczne] http://statystyka. policja.pl/download/20/273613/Wypadki2017.pdf [dostęp: 26.10.2018].

Krajowa Rada Bezpieczeństwa Ruchu Drogowego, 2018: Stan bezpieczeństwa ruchu drogowego oraz działania realizowane w tym zakresie w 2017 r., [źródło elektroniczne] http://www. krbrd.gov.pl/files/file_add/download/424_stan-bezpieczenstwa-ruchu-drogowego-orazdzialania-realizowane-w-tym-zakresie-w-2017.pdf [dostęp: 26.10.2018]. 
Ministerstwo Spraw Wewnętrznych i Administracji, 2018: Raport o stanie bezpieczeństwa w Polsce w 2017 roku, Warszawa.

Najwyższa Izba Kontroli, 2014: Bezpieczeństwo ruchu drogowego. Informacja o wynikach kontroli, [źródło elektroniczne] https://www.nik.gov.pl/plik/id,7572,vp,9503.pdf [dostęp: 30.10.2018].

Adres do korespondencji:

prof. dr hab. Bogdan Klepacki

(https://orcid.org/0000-0003-3483-7530)

Szkoła Główna Gospodarstwa Wiejskiego w Warszawie

Wydział Nauk Ekonomicznych

Katedra Logistyki

ul. Nowoursynowska 166, 02-787 Warszawa

e-mail: bogdan_klepacki@sggw.pl

Malgorzata Koper

(https://orcid.org/0000-0002-6218-0073) 



\title{
Ekonomika i Organizacja Logistyki \\ 3 (3), 2018, 61-68
}

DOI: 10.22630/EIOL.2018.3.3.22

\section{Magdalena Nowik}

Uniwersytet Opolski

\section{Big Data jako wsparcie w zarządzaniu lańcuchami dostaw Big Data as a support in supply chain management}

\begin{abstract}
Synopsis. Celem artykułu było rozpoznanie korzyści z zastosowania koncepcji Big Data jako istotnego narzędzia do zarządzania i optymalizacji łańcuchów dostaw oraz procesów logistycznych. Na początku opracowania wyjaśniono pojęcie Big Data oraz określono główne cechy tej koncepcji. W kolejnej części wskazano na obszary zastosowania Big Data oraz podano przykłady użycia tego rozwiązania w łańcuchach dostaw oraz logistyce. Z badań wynika, że analiza Big Data może znacznie przyczynić się do rozwoju łańcuchów dostaw oraz ogniw w nich funkcjonujących.
\end{abstract}

Słowa kluczowe: Big Data, zarządzanie łańcuchem dostaw, logistyka

\begin{abstract}
The aim of the article was to recognize the benefits of the Big Data concept as an important tool for managing and optimizing supply chains and logistics processes. At the beginning of the elaboration, the Big Data notion was clarified and the main features of the concept were defined. The next part shows the application areas of Big Data and gives examples of the use of this solution in supply chains and logistics. The research showed that the Big Data analysis can significantly contribute to the development of supply chains and cells functioning in them.
\end{abstract}

Key words: Big Data, supply chain management, logistics

\section{Wstęp}

Wraz z postępującym rozwojem technologii informatycznych, trwającą cyfryzacją czy powstawaniem nowych koncepcji, modeli i metod zarządzania, organizacji pracy znacznie zwiększyła się ilość danych, jaką zbierają i przechowują przedsiębiorstwa czy instytucje. Łączy się to z powstaniem nowych źródeł danych, nowych typów poszukiwanych i pożądanych informacji czy też samych technik ich zbierania oraz analizy. Przykładem może być zastosowanie technologii RFID (ang. radio-frequency identification). Informacje zapisane na poszczególnych tagach (czytnikach) zbierane są przez kolejne bramy czy też urządzenia takie jak skanery, które bezpośrednio przesyłają je do serwera, gdzie są zapisywane, przetwarzane i archiwizowane. Dane te dotyczą wielu aspektów związanych z towarem: od numeru partii, przez wagę, aż po miejsce przeznaczenia oraz 
specyficzne dane charakterystyczne dla poszczególnych towarów. Przed powstaniem tego typu technologii ilość informacji dotyczących danego produktu była znacznie mniejsza, a samą ewidencję prowadzono za pomocą arkuszy papieru, ksiąg czy prostych arkuszy kalkulacyjnych.

Wzrost ilości danych oraz ich różnorodność przyczyniły się do powstania wielu koncepcji i sposobów ich wykorzystania w biznesie, bowiem niemalże każda informacja poddana odpowiedniej analizie czy porównaniu może nieść za sobą bardzo dużą wartość dla poszczególnych firm oraz całych łańcuchów dostaw.

Jak podaje IDC ${ }^{1}$, w 2020 roku można spodziewać się, że ilość wytworzonych danych na świecie przekroczy $40 \mathrm{ZB}^{2}$, a w 2025 roku liczba ta wyniesie 175 ZB (rys. 1). Oznacza to ogromny przyrost w porównaniu do początku 2017 roku, kiedy ilość wytworzonych danych nie przekroczyła 20 ZB [Reinsel i in. 2017]. Tak duża ilość informacji, także dotyczących klientów, ich zapotrzebowania, procesów produkcji, zasobów, czasu trwania poszczególnych operacji, niesie za sobą bardzo duże możliwości dla menadżerów w łańcuchach dostaw. Rozwiązaniem w tym zakresie może być koncepcja Big Data.

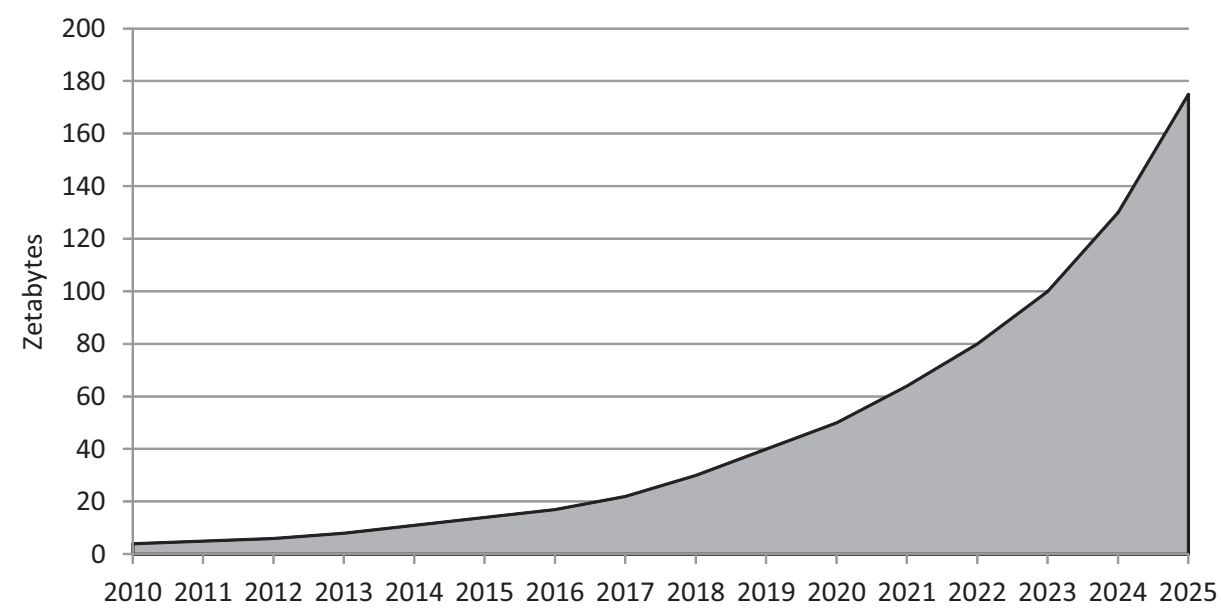

Rysunek 1. Przewidywany roczny przyrost danych cyfrowych ogółem na świecie do 2025 roku Figure 1. Expected annual growth of digital data total in the world until 2025

Źródło: [Reinsel i in. 2017].

\section{Cel i metodyka badań}

Celem badań było rozpoznanie korzyści z zastosowania nowej koncepcji, jaką jest Big Data, z uwzględnieniem jej charakterystyki. Istotą analiz jest także ocena znaczenia tej koncepcji dla łańcuchów dostaw i logistyki poprzez przedstawienie przykładów firm, które już wdrożyły to rozwiązanie. Źródłem danych do analizy były literatura dotycząca

\footnotetext{
${ }^{1}$ International Data Corporation - amerykańska firma analityczna dostarczająca informacje i dane dla biznesu wspomagające podejmowanie decyzji.

${ }^{2}$ Zetabajt to jednostka przedstawiania ilości informacji cyfrowych. 1 ZB to bilion GB.
} 
koncepcji Big Data, raporty firm odnoszące się do cyfryzacji, analityki, logistyki oraz zarządzania łańcuchem dostaw. Ponadto, $w$ opracowaniu uwzględniono informacje $\mathrm{z}$ artykułów zamieszczonych na portalach skupiających się wokół logistyki, analityki czy biznesu (zarówno polskojęzycznych, jak i anglojęzycznych).

\section{Charakterystyka Big Data}

Pojęcie Big Data (tłumacząc dosłownie na język polski: duże dane) nie jest jednoznacznie zdefiniowane, bowiem w literaturze różnie jest interpretowane. Jak podaje firma Gartner, specjalizująca się w analityce i doradztwie dla przedsiębiorstw, Big Data to ,informacje o dużej wielkości, szybkości i/lub różnorodności, które wymagają opłacalnych, innowacyjnych metod przetwarzania informacji, które pozwolą na lepszy wgląd, podejmowanie decyzji oraz automatyzację procesów" [Gartner IT Glossary b.d.]. Inną definicję podał Surma [2017], według którego są to ,aktywa informacyjne charakteryzujące się dużym wolumenem, intensywnym przyrostem w czasie oraz różnorodnością formatów danych, które wymagają adekwatnych metod składowania, przetwarzania i analizowania w celu osiągnięcia określonych celów (ekonomicznych, społecznych, politycznych itp.)". Istnieje wiele innych definicji dotyczących analizowanego zagadnienia, jednak większość z nich wskazuje na kilka szczególnych cech charakterystycznych dla tego pojęcia.

Pierwszą cechą wskazywaną w definicjach Big Data jest wielkość danych, które pozyskiwane są niemal z każdego możliwego źródła, a w odniesieniu do logistyki - na każdym etapie i z każdego ogniwa łańcucha dostaw. Łączy się to głównie z wykorzystaniem nowych technologii oraz chęcią i obowiązkiem monitorowania procesów, po to aby je kontrolować i obserwować, jakie zachodzą zjawiska oraz tendencje.

Kolejnym aspektem jest szybkość kolekcjonowania informacji, ich zapisu i powstawania oraz zmienność. Firmy transportowe otrzymują informacje o położeniu geograficznym danego ciągnika siodłowego oraz jego prędkości w czasie rzeczywistym. Przedsiębiorstwa produkcyjne zbierają dane na temat każdego surowca, jego ilości, lokalizacji w procesie produkcyjnym (na jakim etapie znajduje się), wielkości produkcji, czasie i opóźnieniach. W centrach dystrybucyjnych i magazynach na bieżąco monitoruje się położenie produktów, ich ilość, pochodzenie, miejsce przeznaczenia itd. Dane mogą mieć źródła w każdym miejscu czy ogniwie w łańcuchu dostaw i są pobierane oraz zapisywane z dokładnością co do minuty czy sekundy. Tworzy to ogromne zbiory danych. Ponadto, informacje te mogą ulegać szybkim zmianom, co wynika ze specyfiki danego procesu np. dane o wielkości produkcji mogą zmieniać się z szybkością produkcji jednostki towaru np. co minutę.

Następną cechą Big Data jest ich różnorodność, co oznacza, że nie posiadają one tego samego formatu czy struktury. Mogą być zapisami z kamery w hali produkcyjnej, plikami zawierającymi zapisy GPS, arkuszami kalkulacyjnymi wskazującymi na wielkość sprzedaży czy fotografią przedstawiającą stan techniczny pojazdu [Hyunjoung i Sohn 2016].

Zebrane dane powinny zostać poddane szczegółowym analizom i zestawieniom przynoszącym wnioski, pomagającym w podejmowaniu decyzji. Informacje, czasem na pozór całkowicie ze sobą niezwiązane, po porównaniu czy zestawieniu mogą dostarczyć wiedzy przedsiębiorstwom w łańcuchach dostaw na temat wzajemnych zależności np. między użyciem poszczególnych surowców w produkcji a czasem produkcji czy ilością zwrotów od klientów. 
Big Data to zbiory danych, które charakteryzują się różnorodnością, zmiennością, szybkością powstawania oraz wielkością. W myśl koncepcji powinny one być poddane szczegółowej analizie, zestawione wzajemnie ze sobą, po to aby po wykryciu zależności, ryzyka itp. firmy mogły podejmować racjonalne decyzje, które pozwolą im na zdobycie przewagi konkurencyjnej, dostosowanie się do zmian na rynku czy reakcji na nagłe, nieprzewidziane wydarzenia. Ważne jest, by zdawać sobie sprawę z tego, że Big Data nie odnosi się jedynie do danych, ale także do różnorodności technik analizy, liczby osób, specjalistów do spraw analityki czy technologii wspomagających te czynności.

\section{Wyniki badań}

Z raportu firmy DHL z 2013 roku wynika, że branża logistyczna bazuje na informacjach, jest nimi „napędzana”, przez co koncepcja Big Data jest dobrym rozwiązaniem dla łańcuchów dostaw i operacji logistycznych. Autorzy w raporcie wskazali na pięć głównych obszarów zastosowania Big Data w logistyce [DHL International]: optymalizacja; analiza wymagań klientów i poziomu ich zadowolenia; integracja z klientem biznesowym; analiza szczegółowych informacji w łańcuchach dostaw; kolekcjonowanie i analiza danych globalnych oraz lokalnych. Wskazuje to na znaczny potencjał zastosowania analityki Big Data w logistyce i zarządzaniu łańcuchem dostaw.

Firma SAP w jednym z artykułów wskazała na szanse i korzyści, jakie może przynieść użycie Big Data. Wyróżniła m.in. wpływ zmiany gospodarowania zapasami na proces interaktywny. Przykładem w tym zakresie może być przewidywanie z dużą dokładnością zapotrzebowania klientów na poszczególne towary i natychmiastowe podejmowanie działań związanych z uzupełnieniem braków. Kolejną możliwością jest przeprowadzanie symulacji, analiz i eksperymentów dotyczących podejmowania decyzji, dzięki czemu łatwiej jest zrozumieć ich wpływ na poszczególne ogniwa łańcucha dostaw, procesy itd. Inną korzyścią, jaką daje Big Data w zakresie zarządzania łańcuchem dostaw, jest wykrywanie relacji, zależności między niektórymi czynnikami, co może poskutkować np. znalezieniem problemów i wyeliminowaniem ryzyka w łańcuchu dostaw przed jego pojawieniem się [SAP 2014].

Przykładem zastosowania Big Data w działalności transportowej jest przypadek firmy UPS, która używa technologii geolokalizacji, modułów GPS w swoich pojazdach, po to aby monitorować trasy, miejsce położenia pojazdów czy pracę kierowców. Każdego dnia do bazy danych trafiają tysiące odczytów. Firma zdecydowała się na skorzystanie z oprogramowania do analizy danych (Big Data). Wynikiem tego była redukcja przejechanych kilometrów aż o $48 \mathrm{mln}$, co pozwoliło na oszczędzenie 14 mln 1 paliwa, a w konsekwencji zmniejszenie emisji dwutlenku węgla o $30 \mathrm{mln} \mathrm{kg}$, co jest niezaprzeczalnie pozytywnym efektem dla środowiska. Ponadto wzrósł poziom bezpieczeństwa kierowców, ponieważ trasy tworzone z użyciem algorytmu dobierane są w taki sposób, aby zawierały jak najmniej skrzyżowań, na których należy skręcić. Zmniejsza to prawdopodobieństwo wypadku, a także redukuje zużycie paliwa i czas, ponieważ samochody nie muszą czekać przed wykonaniem manewru (na sygnał zielony czy reakcję pozostałych uczestników na drodze). Wcześniej przebiegi tras częściowo były tworzone na siatce sprawdzonych, najbardziej efektywnych dróg [Mayer-Schonberger i Cukier 2014]. Ten przykład ilustruje, jaki wpływ może mieć wykorzystanie Big Data w transporcie, który łączy poszczegól- 
ne ogniwa łańcucha dostaw. Skrócenie czasu transportu, ograniczenie kosztów, redukcja emisji to efekty, których osiągnięcie może warunkować przewagę konkurencyjną lub powodzenie całego łańcucha.

Innym przykładem jest firma Rolls-Royce produkująca silniki m.in. do samolotów. Wykorzystuje ona analitykę Big Data w trzech sektorach swojej działalności: projektowaniu silników, produkcji oraz obsłudze posprzedażowej. Podczas tworzenia silników odrzutowych generowane są dziesiątki terabajtów danych. Powstają one przy przygotowywaniu symulacji, które w późniejszym czasie są analizowane pod kątem tego, czy mechanizm zadziała poprawnie, czy jest bezpieczny itd. W procesie produkcji firma wykorzystuje wiele sensorów do automatycznego monitorowania poszczególnych etapów procesu oraz powstałych części, komponentów, produktów. Dzięki temu możliwa jest pełna kontrola procesu produkcyjnego na każdym jego etapie. Obsługa posprzedażowa polega na tym, że każdy nawet najmniejszy komponent silnika wyposażony jest w sensor, który wysyła do bazy dane o wszelkich zmianach. W centrali specjaliści decydują, co zrobić w każdym przypadku zaistnienia takiej zmiany.

Analiza Big Data pozwala także na przewidywanie błędów, problemów, które wystąpią kilka dni lub nawet tygodni przed tym, zanim naprawdę będą miały miejsce. Dzięki temu linie lotnicze z dużym wyprzedzeniem dysponują wiedzą, kiedy i jakie maszyny nie będą zdatne do użytku w związku z pracami serwisowymi, co pozwala im na przygotowanie się do takiej sytuacji i zareagowanie na nią. Wobec tego firma zapewnia najwyższy poziom bezpieczeństwa dla tysięcy pasażerów, którzy korzystają z samolotów wyposażonych w silniki Rolls-Royce, a w odniesieniu do zarządzania łańcuchami dostaw umożliwia nieprzerwaną realizacje zaplanowanych operacji transportowych. Rezultatem wprowadzenia Big Data było ulepszenie i poprawa procesu projektowania silników dzięki redukcji błędów, jakie zachodziły wcześniej. Proces produkcyjny został skrócony, a sama jakość produktów uległa znacznemu podwyższeniu. Wszystkie błędy i anomalie rejestrowane są bowiem w trakcie używania sprzętu przez klientów, na bieżąco przysłane są nie tylko do analityków, specjalistów i działu serwisu, ale także do osób zajmujących się projektowaniem oraz produkcją, dzięki czemu są analizowane i brane pod uwagę przy projektowaniu i produkcji kolejnych silników.

Oprócz poprawy wszystkich wymienionych procesów Big Data przyczyniło się do zmiany modelu biznesowego, który wcześniej opierał się na produkcji i sprzedaży silników, a w obecnej chwili skupia się głównie wokół obsługi sprzedanego już produktu, monitorowania go przez cały czas oraz serwisowania [Marr 2016]. Przykład Rolls-Royce obrazuje, jak Big Data może wpłynąć na powstawanie produktu, jego produkcję czy późniejszą obsługę posprzedażową, która dla dużych klientów takich jak linie lotnicze jest niezwykle istotna, aby zapewnić trwałość procesu transportowego.

Innym przykładem odnoszącym się do łańcuchów dostaw jest zastosowanie analityki Big Data przez firmę Lenovo - producenta sprzętu elektronicznego, głównie komputerów w latach 2010-2011. W tym czasie miały miejsce trzy katastrofy naturalne: trzęsienie ziemi u wybrzeża Japonii, wybuch wulkanu na Islandii czy powódź w Tajlandii. Wpłynęły one znacząco na możliwości dostarczenia komponentów do produkcji komputerów przez dostawców czy też operacje wewnątrz firmy (również podejmowane przez nią, takie jak np. dystrybucja towarów). W odpowiedzi na taką sytuację Lenovo opracowało w bardzo krótkim czasie strategię i plan działania dla całego łańcucha dostaw. Okazało się, 
że decyzje wówczas podjęte, poparte analizą Big Data, korzystnie wpłynęły na pozycję firmy, bowiem w tym czasie jej udział w rynku wzrósł o sześć punktów procentowych. Konkurenci tej firmy (Asus, Toshiba czy Dell) nie zdołały wypracować takich strategii, w związku z czym ich udział w rynku odpowiednio zmalał [Marciniak i Szymczak 2015]. W tym przypadku analiza Big Data znacznie wpłynęła na zmniejszenie ryzyka w całym łańcuchu dostaw, który dzięki podjętym decyzjom stał się wyjątkowo odporny na szybko zmieniające się warunki na świecie.

W Polsce analizę Big Data wprowadziła firma Inter Cars SA - dystrybutor akcesoriów i części samochodowych. Wdrożono ją w zakresie dostarczania części samochodowych m.in. dla warsztatów. Dokonywana jest tam prognoza zapotrzebowania dla każdego klienta (placówki) i na jej podstawie odbywa się dystrybucja komponentów do poszczególnych miejsc [Kryśkiewicz 2017]. Pozwala to na płynne zarządzanie liczbą części w placówkach zaopatrywanych przez Inter Cars SA, a także czasowe zaopatrzenie firmy w potrzebne produkty. Klient $\mathrm{w}$ tym przypadku nie musi podejmować żadnych działań, potrzebny towar zostanie mu dostarczony w określonym czasie.

Łańcuchy dostaw mogą różnić się od siebie w zależności od obszaru czy branży, w jakich działają. Identyfikuje się aż sześć obszarów, w których znajduje zastosowanie Big Data, w celu odpowiedniego zarządzania łańcuchem dostaw [Lopez 2017]:

1. Przejrzystość danych i ich analizy, po to aby menadżerowie mogli w łatwy sposób wyciągnąć wnioski, podjąć decyzje.

2. Dopasowanie podaży do popytu poprzez efektywne prognozowanie.

3. Optymalizacja kanałów - dane pozwalają na wybór odpowiednich środków transportu czy lokalizacji punktów sprzedaży.

4. Tworzenie zintegrowanych kanałów - łączenie magazynowania, dystrybucji, produkcji poprzez użycie sensorów, czytników, które dostarczą wiedzy o procesie i produkcie, zapotrzebowaniu i wskażą na to, że należy uzupełnić zapas.

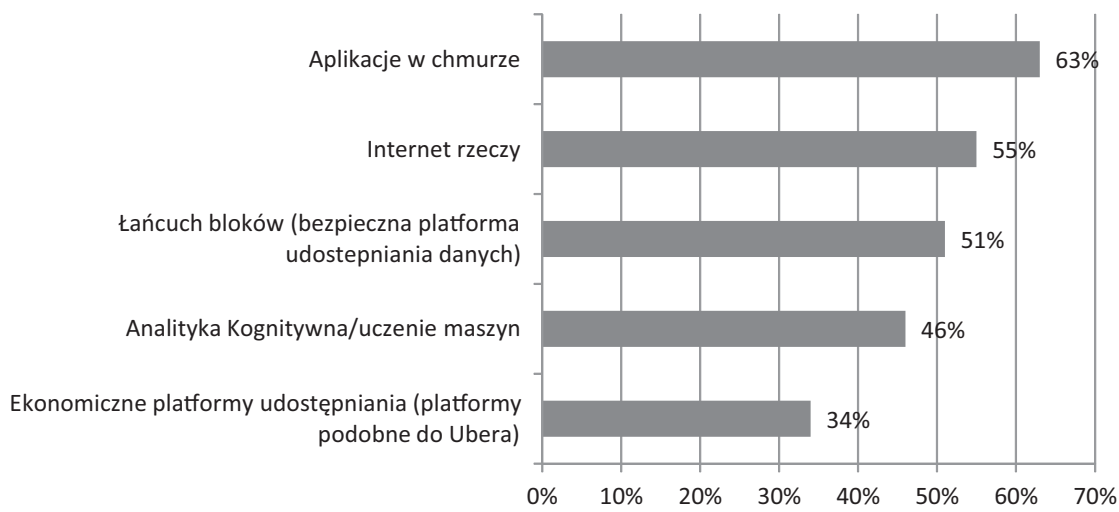

Rysunek 2. Ranking istotności technologii informatycznej lub analitycznej dla logistyki i zarządzania łańcuchem dostaw

Figure 2. Ranking of the importance of information technology or analytical technology for logistics and supply chain management

Źródło: opracowanie własne na podstawie [DHL International 2017]. 
5. Tworzenie połączonych procesów, w których maszyny będą przesyłać dane, które po analizie dokonanej przez algorytmy poinformują menadżerów o danej sytuacji, stanie i ewentualnych zmianach.

6. Poprawa bezpieczeństwa i produktywności pracowników np. poprzez zastosowanie rozszerzonej rzeczywistości, która wskaże im, jakie czynności powinni wykonywać. Oprócz wymienionych obszarów Big Data może pomóc w tworzeniu „zielonych” łańcuchów dostaw poprzez redukcję zużycia paliwa, a tym samym zmniejszenie emisji czy też projektowanie procesów produkcyjnych nastawionych na ochronę środowiska np. poprzez redukcję zużycia surowców nieodnawialnych i wykorzystanie surowców odnawialnych, redukcję zużycia energii.

Według raportu DHL Supply Chain (rys. 2), przeprowadzonego z udziałem aż 350 ekspertów do spraw łańcuchów dostaw, najbardziej istotną technologią analityczną bądź informatyczną jest Big Data. Wskazało na nią aż 73\% ankietowanych. Oznacza to, że specjaliści z całego świata doceniają znaczenie tej koncepcji dla logistyki i łańcuchów dostaw [DHL International 2017].

\section{Podsumowanie i wnioski}

Przedstawione przykłady wskazują, że odpowiednie użycie Big Data może „uodpornić” łańcuch dostaw na pojawiające się zakłócenia, których nie sposób przewidzieć. Koncepcja poszerza wachlarz optymalizacji i ulepszeń w łańcuchu dostaw, często znajdując niestandardowe rozwiązania wcześniej nierozpatrywane. Stosunkowo małym kosztem potrafi znacznie wpłynąć na działanie łańcucha dostaw, jego efektywność, wydajność itp. Zastosowanie analizy Dużych Danych w odniesieniu do całego łańcucha dostaw jest nieinwazyjne, ponieważ nie wymaga przekształcenia łańcucha, a jedynie pobiera zbierane w nim informacje i poddaje obróbce. Ponadto może zachodzić w jednym centralnym miejscu i wspierać podejmowanie decyzji.

Specjaliści do spraw łańcuchów dostaw jednoznacznie wskazali w raporcie opublikowanym przez firmę DHL, że Big Data jest najważniejszą technologią informatyczną/analityczną w rozwijaniu i zarządzaniu łańcuchami dostaw. Oznacza to, że przedsiębiorcy zdają sobie sprawę z wartości, jaką niesie korzystanie z tego rozwiązania i widzą jego zastosowanie w przyszłości.

Implementacja Big Data jest łatwiejsza do przeprowadzenia niż przekształcenie łańcucha dostaw, wymiana infrastruktury, zmiana procesów, jakie mają miejsce, co przemawia na korzyść tej koncepcji. Idea Big Data i jej znaczenie stają się coraz bardziej popularne i docenianie. Coraz częściej można znaleźć informacje o jej zastosowaniu i wynikach.

Big Data w przyszłości może przynieść jeszcze większe korzyści dla łańcuchów dostaw. W dobie cyfryzacji, nowych technologii, Internetu rzeczy (ang. Internet of Things - IoT), które znacznie przyczyniają się do powstawania wielu danych o różnej wartości, znaczeniu i zawartości, analiza Big Data jest trafnym sposobem do uzyskania korzyści w skali całego łańcucha dostaw. Może przyczynić się nie tylko do poprawienia jego wydajności i zwiększenia zysków, ale także redukcji wpływu na otaczające środowisko i społeczność, czyli wpisanie się w ideę zrównoważonego rozwoju. 


\section{Literatura}

DHL International, 2013: Big Data in Logistics. A DHL perspective on how to move beyond the hype, Customer Solutions \& Innovation, Troisdorf.

DHL International, 2017: DHL Supply Chain, Digitalization and the Supply Chain: Where are We and What's Next?, [źródło elektroniczne] http://supplychain.dhl.com/LP=975?\&utm medium $=$ PR\&utm_campaign $=$ AO-Digitalization- $1 \& u$ tm_source $=$ PR-GatedComms\%20and [dostęp: 20.04.2018].

Gartner IT Glossary [b.d.]: Big Data, [źródło elektroniczne] https://www.gartner.com/it-glossary/ big-data [dostęp: 20.04.2018].

Hyunjoung L., Sohn I., 2016: Big Data w przemyśle. Jak wykorzystać analizę danych do optymalizacji kosztów procesów?, PWN, Warszawa.

Kryśkiewicz Ł., 2017: Analityka Big Data w Polsce. Jak polskie firmy wykorzystują \#BigData, aby efektywnie konkurować na rynku, [źródło elektroniczne] http://di.com.pl/analityka-bigdata-w-polsce-jak-polskie-firmy-wykorzystuja-bigdata-aby-efektywnie-konkurowac-narynku-58022 [dostęp 21.04.2018].

Lopez E., 2017: How do supply chains use Big Data?, [źródło elektroniczne] https://www.supplychaindive.com/news/how-big-data-application-supply-chain-Deloitte-digital-stack/435866/ [dostęp: 21.04.2018].

Marciniak M., Szymczak M., 2015: Big Data w zarządzaniu łańcuchem dostaw, Gospodarka Materiałowa i Logistyka 7, 8-15.

Marr B., 2016: Big Data in practice. How 45 successful companies used Big Data analytics to deliver extraordinary results, Wiley, Cornwall, UK.

Mayer-Schonberger V., Cukier K., 2014: Big Data. Rewolucja, która zmieni nasze myślenie, pracę i życie, MT Biznes, Warszawa.

Reinsel D., Gantz J., Rydning J., 2017: Data Age 2025: The Evolution of Data to Life-Critical Don't Focus on Big Data; Focus on the Data That's Big, An IDC White Paper, Framingham, USA.

SAP, 2014: Osiąganie korzyści z Big Data: skup się na możliwościach, a nie na przeszkodach, [źródło elektroniczne] https://docplayer.p1/9719617-Osiaganie-korzysci-z-big-data-skupsie-na-mozliwosciach-a-nie-na-przeszkodach.html [dostęp: 21.04.2018].

Surma J., 2017: Cyfryzacja życia w erze Big Data. Człowiek. Biznes. Państwo, Wydawnictwo Naukowe PWN, Warszawa.

Adres do korespondencji:

lic. Magdalena Nowik

(https://orcid.org/0000-0002-1943-0700)

Uniwersytet Opolski

Zakład Logistyki i Marketingu

ul. Ozimska 46a, 45-058 Opole

tel. $(+48) 774016880$

e-mail: magnow95@gmail.com 


\title{
Ekonomika i Organizacja Logistyki \\ 3 (3), 2018, 69-78
}

DOI: 10.22630/EIOL.2018.3.3.23

\author{
Tomasz Rokicki ${ }^{1}$, Stanislaw Bereziński ${ }^{2}$ \\ ${ }^{1}$ Szkoła Główna Gospodarstwa Wiejskiego w Warszawie \\ ${ }^{2}$ Unipolcom S.A.
}

\section{Ocena ryzyka wykorzystania giełd transportowych w działalności firm przewozowych}

\section{Assessment of the risk of using transport exchanges in the activities of transport companies}

\begin{abstract}
Synopsis. Artykuł został poświęcony analizie funkcjonalności giełd transportowych i wskazaniu potencjalnych zagrożeń płynących z ich wykorzystania w pracy przedsiębiorstwa transportowego. Podstawą merytoryczną dla pracy była analiza literatury z zakresu funkcjonowania giełd transportowych, a także informacje pozyskane od dostawców usług giełd transportowych poprzez ich strony internetowe i kontakt telefoniczny. Wykorzystano także wiedzę teoretyczną i praktyczną jednego z autorów, który na co dzień pracuje, wykorzystując elektroniczne giełdy transportowe. Stwierdzono, że w dobie rozwoju komunikacji elektronicznej i wzrostu wolumenu przewożonych towarów giełdy transportowe są ważnym elementem systemu transportowego. Na podstawie przeprowadzonej analizy zauważono, że wykorzystanie giełd transportowych powoduje liczne zagrożenia, z których wiele firm nie zdaje sobie sprawy, nie diagnozuje ich i im nie przeciwdziała.
\end{abstract}

Słowa kluczowe: transport, giełdy transportowe, zarządzanie ryzykiem

\begin{abstract}
The paper is dedicated to the analysis of the functionality of transport exchange applications and the indication of potential threats arising from their use in everyday work of a transport company. The substantive basis for the paper was a literature analysis in the field of transport exchange applications as well as information obtained from transport exchange service providers through their websites and telephone contact. The theoretical and practical knowledge of the authors who work on a daily basis using electronic freight exchanges applications was also used. It was found that in the era of electronic communication development and the in crease in the volume of transported goods, transport exchange platforms are an important element of the transport system. Based on the conducted analysis it was noted that the use of transport exchange platforms brings with it a number of threats that many companies do not realize and doesn't carry out right actions to diagnose them and counteract.
\end{abstract}

Key words: transport, transport market applications, risk management 


\section{Wstęp}

Istotą funkcjonowania każdego rynku, w tym rynku transportowego, jest spotykanie się strony popytowej z podażową. W przypadku rynku przewozów towarowych stroną podażową są firmy produkcyjne, handlowe i spedycyjne zgłaszające ładunki do przewiezienia. Stroną popytową są firmy posiadające właściwe środki transportowe umożliwiające transportowanie ładunków. Biorąc pod uwagę wielkość rynku drogowych przewozów towarowych, bardzo istotne jest takie kształtowanie tego rynku, aby strony popytowa i podażowa mogły w jak najłatwiejszy sposób kontaktować się ze sobą, co tym samym zapewni jak najbardziej wydajne działanie całego systemu [Rokicki 2016]. W tym celu są rozwijane i wprowadzane różnego rodzaju nowoczesne narzędzia ułatwiające kontakt między kontrahentami. Jednym z takich narzędzi są elektroniczne giełdy transportowe. Są one aplikacjami uruchamianymi poprzez przeglądarki internetowe na komputerach oraz urządzeniach mobilnych. Zasadniczym celem tych platform jest zebranie i przekazanie informacji dotyczących pojawiających się potrzeb przewozowych oraz zgłaszanych możliwości transportowych. Innymi słowy giełdy powinny zapewniać dotarcie informacji o zgłoszonym ładunku do jak największej liczby przewoźników, spośród których zgłaszający wybierze najkorzystniejszego usługodawcę, oraz wyszukanie przez przewoźnika jak największej liczby interesujących go ładunków.

Wyróżnia się podział giełd transportowych ze względu na [Osypchuk 2018]:

- zasięg terytorialny: lokalne, krajowe, międzynarodowe,

- formę dostępu: płatne, bezpłatne,

- specjalizację: branżowe i ogólne,

- dostępność: otwarte, ekskluzywne.

Giełdy transportowe są powszechnie stosowanym narzędziem w pracy firm zajmujących się drogowym transportem towarowym w Europie. Świadczyć może o tym wciąż wzrastająca liczba ich zarejestrowanych użytkowników oraz to, że ponad 80\% firm korzystających z giełd powiązana jest z transportem drogowym [Lewandowski i Dziechciarz 2011].

Słowo ryzyko (z łac. riscare) oznacza odważyć się. Dotyczy ono więc wyboru, a nie nieuchronnego przeznaczenia. Przedsiębiorca prowadząc działalność gospodarczą, jest narażony na ryzyko. Wynika ono zarówno z otoczenia, w którym funkcjonuje przedsiębiorstwo, jak i z wewnętrznych procesów. Brak wiedzy o występowaniu ryzyka może powodować poważne konsekwencje. Przedsiębiorcy powinni uświadomić sobie, że występowania ryzyka oraz mieć koncepcję zarządzania nim [Bernstein 1997, Adamska 2009].

Istnieje wiele publikacji opisujących wpływ i możliwe zastosowania giełd transportowych w pracy firm przewozowych [Lewandowski i Dziechciarz 2011, Palczewska i in. 2012, Bartczak i Barańska 2016]. W większości prace te podkreślają jedynie zalety wykorzystania tego narzędzia. Tylko nieliczne publikacje wskazują istnienie wad, ale nawet one oceniają w pozytywny sposób giełdy transportowe [Leończuk 2013, Kisielewski i Leśniakiewicz 2016].

Autorzy podjęli wysiłek opisowej oceny ryzyka z wykorzystania giełd do pracy firmy transportowej. Ryzyko to jest bowiem przez większość podmiotów niedostrzegane lub pomijane. Brak świadomości jego istnienia bądź jego lekceważenie przypuszczalnie stanowi zagrożenie dla działalności firmy czy nawet większych fragmentów rynku. 


\section{Cel i metodyka badań}

Celem głównym artykułu była identyfikacja i ocena ryzyka, jakie wynika z zastosowania elektronicznych giełd transportowych w pracy firmy transportowej. Analiza została ograniczona do największych platform tego typu w Europie, tj. Trans.eu, TimoCom, Wtransnet, Teleroute, B2P.

Na potrzeby artykułu zostały postawione dwie hipotezy badawcze:

1. Wybrane funkcje giełd transportowych nie zabezpieczają korzystających z nich przewoźników przed potencjalnym ryzykiem, dając w zamian jedynie pozorne poczucie bezpieczeństwa.

2. Ryzyko płynące $z$ wykorzystania giełd transportowych jest często nieświadome i pomijane przy analizie ryzyka prowadzonej przez firmy transportowe działalności.

Źródłem materiałów użytych do przygotowania pracy był przegląd literatury dotyczącej giełd transportowych, zarządzania przedsiębiorstwem transportowym oraz informacje dotyczące tych giełd pozyskane ze stron internetowych usługodawców, a także w trakcie wywiadów telefonicznych z ich infoliniami sprzedażowymi. Zastosowano metodę obserwacji uczestniczącej. Dodatkowo wykorzystano dane statystyczne pochodzące $\mathrm{z}$ baz Eurostat i GUS. Do analizy i prezentacji wyników wykorzystano opisową, tabelaryczną i graficzną metodę.

\section{Wyniki badań}

\section{Charakterystyka branży}

Drogowy transport towarowy zajmował szczególne miejsce w strukturze przewozów ładunków w Europie. Jego udział w latach 2008-2017 cechował niewielki, ale w miarę stabilny wzrost. Podobnie było również w przypadku transportu drogowego w Polsce (tab. 1).

Warto podkreślić, że realizowane przez polskie firmy przewozy nie dotyczyły jedynie terytorium kraju. Polscy przewoźnicy byli jednym z najważniejszych graczy na rynku przewozów międzynarodowych w Europie (rys.).

Tabela 1. Drogowy transport towarowy w Polsce i UE w latach 2008-2017 (mld tkm)

Table 1. Road cargo transport in Poland and EU in 2008-2017 (billions tkm)

\begin{tabular}{|l|c|c|c|c|c|c|c|c|c|c|}
\hline Wyszczególnienie & 2008 & 2009 & 2010 & 2011 & 2012 & 2013 & 2014 & 2015 & 2016 & 2017 \\
\hline $\begin{array}{l}\text { Praca przewozowa } \\
\text { w UE (mld tkm) }\end{array}$ & 1891 & 1700 & 1756 & 1741 & 1687 & 1711 & 1720 & 1762 & 1831 & 1913 \\
\hline $\begin{array}{l}\text { Praca przewozowa } \\
\text { w Polsce (mld tkm) }\end{array}$ & 165 & 181 & 202 & 208 & 222 & 248 & 251 & 261 & 291 & 335 \\
\hline $\begin{array}{l}\text { Udział Polski } \\
\text { w przewozach w UE (\%) }\end{array}$ & 8,72 & 10,63 & 11,52 & 11,93 & 13,18 & 14,47 & 14,59 & 14,80 & 15,88 & 17,52 \\
\hline
\end{tabular}

Źródło: opracowanie własne na podstawie: Gross domestic expenditure on R\&D (GERD), [Eurostat 2018]. 


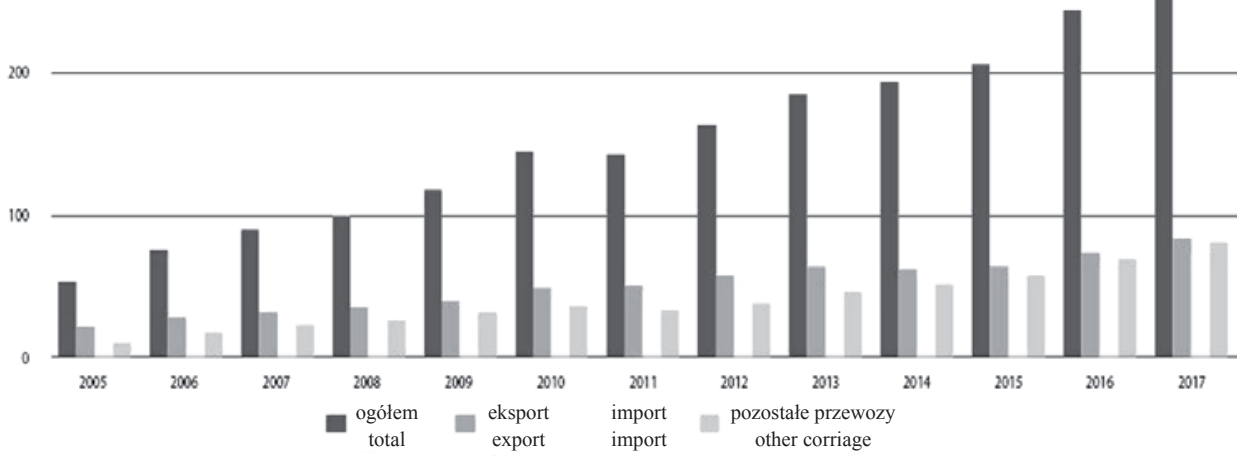

Rysunek. Przewozy ładunków w międzynarodowym transporcie samochodowym w Polsce w latach 2005-2017 (mln t)

Figure. Freight transport in international road transport in Poland in 2005-2017 (million t)

Źródło: [Eurostat 2018, GUS 2018].

\section{Funkcjonalność giełd i ich ocena przez firmy transportowe}

Funkcjonalność giełd transportowych była przedmiotem wielu opracowań naukowych i branżowych [Leończuk 2013, Kisielewski i Leśniakiewicz 2016]. Na potrzeby tej pracy należy wymienić jedynie główne funkcje oferowane przez rożne platformy, o których informacje zebrano na stronach internetowych poszczególnych usługodawców oraz w trakcie rozmów telefonicznych z ich liniami sprzedażowymi. Wyróżniono następujące funkcjonalności giełd ${ }^{1}$ :

- baza danych firm transportowych, spedycyjnych i handlowo-produkcyjnych,

- giełda ładunków, pojazdów i powierzchni magazynowych,

- przetargi na dostawę usług transportowych,

- windykacja,

- ubezpieczenia faktur, polisy odpowiedzialności cywilnej, ubezpieczenia cargo,

- forum,

- komunikator,

- aktualności branżowe,

- wystawianie zleceń i dokumentów przewozowych.

1 https://www.timocom.pl/ [dostęp:s 24.09.2018], rozmowa telefoniczna z linią sprzedażową 24.09.2018 r.;https://www.wtransnet.com/pl/ [dostęp: 24.09.2018], rozmowa telefoniczna z linią sprzedażową 24.09.2018 r.; https://www.trans.eu/pl/ [dostęp: 24.09.2018], rozmowa telefoniczna z linią sprzedażową 24.09.2018 r.; https://www.b2pweb.com/ [dostęp: 24.09.2018], rozmowa telefoniczna z linią sprzedażową 24.09.2018 r.; https:/teleroute.com/ [dostęp: 24.09.2018], rozmowa telefoniczna $\mathrm{z}$ linią sprzedażową 24.09.2018 r. 
Na podstawie powyższej listy należy stwierdzić, że giełdy transportowe oferują pakiety kompleksowych usług obejmujących praktycznie wszystkie obszary działalności firmy transportowej. Jak wykazują przeprowadzone badania [Lewandowski, Dziechciarz 2011], giełdy transportowe są oceniane przez swoich użytkowników jednoznacznie pozytywnie. Usługobiorcy podkreślają dużą rolę giełd transportowych w prowadzonej przez siebie działalności, a także wysoką jakość oferowanych usług. Pozytywna ocena giełd transportowych wystawiona przez ich użytkowników może być dowodem na to, że firmy z nich korzystające nie poniosły dotychczas negatywnych skutków ryzyka korzystania z tych platform lub też akceptują to ryzyko i umiejętnie nim zarządzają.

\section{Ryzyko w prowadzeniu firmy transportowej a gieldy transportowe}

Temat zarządzania ryzykiem w firmach transportowych był przedmiotem wielu publikacji [Stokłosa 2011]. Każda firma działająca na rynku ponosi ryzyko związane z prowadzoną przez siebie działalnością. Według internetowej Encyklopedii zarządzania ryzyko jest prawdopodobieństwem, że podmiot gospodarczy poniesie straty w następstwie podjęcia danej decyzji ekonomicznej [Czerwonka i Cież 2008]. Wszystkie obszary działalności oraz elementy struktury firmy narażone są na rożnego rodzaju zagrożenia. Na część z nich firma ma wpływ, ale są też takie pozostające poza jej kontrolą. W konsekwencji podmioty zajmujące się wykonywaniem przewozów powinny przygotowywać własne mapy zagrożeń i analizować istniejące ryzyko prowadzonej działalności. W przypadku dużych firm często można spotkać się ze sformalizowanymi procedurami w postaci strategii zarządzania ryzykiem oraz dokumentów opisujących procedury postępowania w poszczególnych przypadkach. W mniejszych firmach te sformalizowane dokumenty są często zastępowane przez zbiory dobrych praktyk przekazywanych między pracownikami. Często jednak zdarza się, że tworzone dokumenty są źle opracowywane i nie uwzględniają pewnych grup zagrożeń lub też ryzyko nie podlega w ogóle kompleksowej ocenie [Piekarski i in. 2015, Romanow i in. 2017].

Błędnym, choć często spotykanym podejściem, jest utożsamianie ryzyka $\mathrm{w}$ transporcie jedynie z czynnikami, które mogą doprowadzić do szkody w przewożonej przesyłce. W rzeczywistości katalog zagrożeń, na które narażona jest firma transportowa, jest znacznie szerszy i obejmuje takie problemy jak nieterminowe płatności należności za zrealizowaną usługę (w tym oszustwa ze strony kontrahentów) czy zmiany otoczenia organizacyjnego, a w szczególności zmiany w obowiązujących przepisach prawa. Oczywiste wydaje się zatem, że korzystanie z giełd transportowych, mających zastosowanie $\mathrm{w}$ wielu obszarach funkcjonowania firmy transportowej, wiąże się z istnieniem pewnego ryzyka [Cyganik 2014].

Zarządzanie ryzykiem obejmuje trzy etapy: jego identyfikację, zmierzenie oraz akceptację lub odrzucenie. Ryzyko powinno być oceniane w szczególności poprzez dwa kryteria: prawdopodobieństwo jego wystąpienia oraz skutek wynikły z jego zaistnienia. Jeśli oceniać korzystanie z giełd transportowych pod względem tych właśnie kryteriów, to należy uznać, że prawdopodobieństwo zaistnienia różnego rodzaju ryzyka jest relatywnie niewielkie, ale skutek jego pojawienia się może być bardzo dotkliwy [Walasek i Miszczak 2013, Maj 2017]. Istnieje wiele wskaźników próbujących w sposób zwięzły opisać ryzyko. Jednym z tych wskaźników jest współczynnik istotności ryzyka. Wskaźnik 
ten jest wykorzystywany w różnych obszarach ludzkiej działalności, takich jak: finanse [Szczepankiewicz 2016] czy medycyna [Dereń 2017], i może mieć swoje zastosowanie także w transporcie. Jest to iloczyn prawdopodobieństwa ryzyka oraz skutków jego wystąpienia i jest obliczany według formuły:

$$
\mathrm{IR}=\mathrm{P} \cdot \mathrm{S}
$$

gdzie:

IR - współczynnik istotności ryzyka, $\mathrm{P}$ - prawdopodobieństwo wystąpienia ryzyka wyrażone w procentach, $\mathrm{S}$ - skutek wystąpienia ryzyka opisany według przyjętej skali punktowej.

Parametry $\mathrm{P}$ oraz $\mathrm{S}$ będą oczywiście przyjmować różne wartości w zależności od tego, jak aktywnie dana firma korzysta $\mathrm{z}$ giełd internetowych oraz jak funkcjonuje system kontroli tej firmy.

Biorąc pod uwage powyższe rozważania, autorzy zdiagnozowali ryzyka w korzystaniu z giełd transportowych i przedstawili je w tabeli 2. Wskazano również potencjalny sposób eliminacji tego ryzyka.

Tabela 2. Czynniki ryzyka w korzystaniu z giełd transportowych w pracy firm transportowych Table 2. Risk factors in the use of transport exchange applications for transport companies

\begin{tabular}{|c|c|c|c|}
\hline Ryzyko & Opis ryzyka & Skutek & $\begin{array}{c}\text { Sposób eliminacji } \\
\text { ryzyka }\end{array}$ \\
\hline 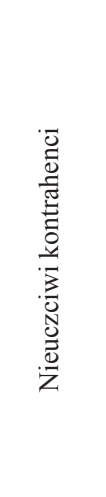 & $\begin{array}{l}\text { Wiele firm uważa, że wszyscy klienci zareje- } \\
\text { strowani na giełdzie zostali już zweryfikowa- } \\
\text { ni przez usługodawców. Nie przeprowadzają } \\
\text { oni zatem własnej weryfikacji kontrahenta. } \\
\text { W rzeczywistości weryfikacja przez usługo- } \\
\text { dawców ogranicza się do sprawdzenia do- } \\
\text { kumentów rejestrowych i licencji, odebrania } \\
\text { referencji oraz sprawdzenia danych finanso- } \\
\text { wych firmy w wywiadowni gospodarczej. } \\
\text { Taka weryfikacja nie pozwala jednak często } \\
\text { na realne ocenienie, jakim płatnikiem jest } \\
\text { dany klient i jaką ma on kulturę prowadzenia } \\
\text { biznesu. Weryfikacja ta tylko zmniejsza, a nie } \\
\text { eliminuje ryzyko. Istniejąca bariera wejścia } \\
\text { na giełdę nie stanowi znaczącego ,sita”. }\end{array}$ & $\begin{array}{l}\text { Firmy nawiązują współ- } \\
\text { pracę z klientami, którzy } \\
\text { opóźniają płatność, co } \\
\text { doprowadza przewoźni- } \\
\text { ków do trudnej sytuacji } \\
\text { finansowej. }\end{array}$ & $\begin{array}{l}\text { Wprowadzenie wła- } \\
\text { snej weryfikacji kon- } \\
\text { trahentów, najlepiej } \\
\text { poprzez referencje od } \\
\text { wielu firm, tak aby } \\
\text { zminimalizować ry- } \\
\text { zyko oszustwa. Przy } \\
\text { pierwszych zleceniach } \\
\text { współpraca na zasadzie } \\
\text { przedpłaty i przy mniej } \\
\text { istotnych kontraktach, } \\
\text { w przypadku których } \\
\text { ewentualne problemy } \\
\text { będą miały niewielkie } \\
\text { konsekwencje. }\end{array}$ \\
\hline 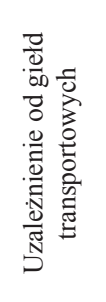 & $\begin{array}{l}\text { Firmy nadmiernie przywiązują się do giełd } \\
\text { transportowych, pozyskując z nich większość } \\
\text { ładunków zamiast poszukiwać bezpośred- } \\
\text { nich kontaktów z firmami produkcyjnymi, } \\
\text { wykorzystując giełdy jedynie jako platformy } \\
\text { nawiązania początkowego kontaktu i przeno- } \\
\text { sząc współpracę na kolejnych etapach poza } \\
\text { giełdę. }\end{array}$ & $\begin{array}{l}\text { Firma uzależniona od ła- } \\
\text { dunków z giełdy w mo- } \\
\text { mencie utraty dostępu do } \\
\text { platformy nie umie odna- } \\
\text { leźć się na rynku. }\end{array}$ & $\begin{array}{l}\text { Poszukiwanie alterna- } \\
\text { tywnych form pozy- } \\
\text { skiwania ładunków, } \\
\text { takich jak: bezpośredni } \\
\text { kontakt z firmami pro- } \\
\text { dukcyjnymi działają- } \\
\text { cymi w interesujących } \\
\text { przewoźnika branżach } \\
\text { bądź lokalizacjach. }\end{array}$ \\
\hline
\end{tabular}


Tabela 2. cd.

Table 2. cont.

\begin{tabular}{|c|c|c|c|}
\hline 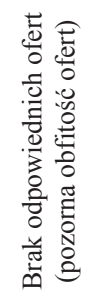 & $\begin{array}{l}\text { Wiele firm wchodzi na giełdy zachęcona } \\
\text { obietnicami wielu ofert ładunków i dużej licz- } \\
\text { by zarejestrowanych kontrahentów. Oferty } \\
\text { często kopiowane i wstawiane po kilka razy, } \\
\text { wstawiane po zmianie kodu pocztowego na } \\
\text { bardzo podobny lub też kopiowane między } \\
\text { poszczególnymi giełdami. Realna liczba wy- } \\
\text { stawionych ładunków jest więc o kilka pro- } \\
\text { cent mniejsza od deklarowanej. }\end{array}$ & $\begin{array}{l}\text { Firmy nie pytają o lub } \\
\text { nie korzystają z okresów } \\
\text { próbnych, wykupując od } \\
\text { razu abonament na usługę } \\
\text { a następnie zauważają, że } \\
\text { w interesujących je rela- } \\
\text { cjach oferta ładunków jest } \\
\text { bardzo ograniczona. }\end{array}$ & $\begin{array}{l}\text { Nietraktowanie giełdy } \\
\text { jako jedynego źródła } \\
\text { ładunków i umiejęt- } \\
\text { ność elastycznego po- } \\
\text { dejścia do wyszukiwa- } \\
\text { nia nowych zleceń. }\end{array}$ \\
\hline 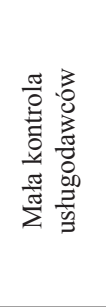 & $\begin{array}{l}\text { Usługodawcy sprawują bardzo ograniczoną } \\
\text { kontrolę nad zachowaniem usługobiorców. } \\
\text { Firmy prowadzące nieuczciwie i nieetyczne } \\
\text { praktyki nie są często karane np. zawiesze- } \\
\text { niem dostępu do giełdy. Co więcej giełdy nie } \\
\text { współpracują ze sobą w tropieniu nieuczci- } \\
\text { wych klientów, którzy często po utracie do- } \\
\text { stępu do jednej z platform przenoszą się na } \\
\text { inną. }\end{array}$ & $\begin{array}{l}\text { Narażenie firmy transpor- } \\
\text { towej na funkcjonowanie } \\
\text { w środowisku, w któ- } \\
\text { rym podmioty działające } \\
\text { w sposób niewłaściwy } \\
\text { i nieetyczny, co może do- } \\
\text { prowadzić do oszustów } \\
\text { i „psucia” rynku. }\end{array}$ & $\begin{array}{l}\text { Wywieranie presji na } \\
\text { usługodawcę. Korzy- } \\
\text { stanie z ochrony praw- } \\
\text { nej. }\end{array}$ \\
\hline 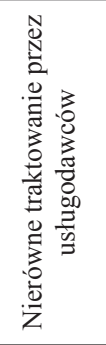 & $\begin{array}{l}\text { Usługodawcy często nie traktują z należytą } \\
\text { starannością skarg i reklamacji małych firm } \\
\text { transportowych, mając świadomość, że fir- } \\
\text { my te przynoszą im bardzo niewielki dochód } \\
\text { oraz że nie są one ich klientami kluczowymi. }\end{array}$ & $\begin{array}{l}\text { Mniejsze firmy transpor- } \\
\text { towe są często dyskrymi- } \\
\text { nowane, a usługodawcy, } \\
\text { którzy powinni stać na } \\
\text { straży interesów każdego } \\
\text { klienta, nie wspierają ich. } \\
\text { W konsekwencji firmy te } \\
\text { muszą zgadzać się często } \\
\text { na gorsze warunki reali- } \\
\text { zowanych umów. }\end{array}$ & $\begin{array}{l}\text { Wywieranie presji na } \\
\text { usługodawcę. Korzy- } \\
\text { stanie z ochrony praw- } \\
\text { nej. }\end{array}$ \\
\hline 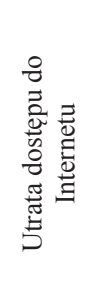 & $\begin{array}{l}\text { Konieczność posiadania stałego dostępu do } \\
\text { Internetu. }\end{array}$ & $\begin{array}{l}\text { Brak dostępu do Interne- } \\
\text { tu oznacza niemożliwość } \\
\text { pozyskania ładunków. } \\
\text { Jeśli więc nie mamy wła- } \\
\text { snej bazy kontaktów, to } \\
\text { w przypadku awarii firma } \\
\text { może zostać bez możli- } \\
\text { wości zdobycia nowych } \\
\text { zleceń. }\end{array}$ & $\begin{array}{l}\text { Zabezpieczenie w po- } \\
\text { staci dodatkowego do- } \\
\text { stawcy Internetu (np. } \\
\text { w formie mobilnej), } \\
\text { który pozwoli na } \\
\text { podtrzymanie pracy } \\
\text { w krótkim czasie. }\end{array}$ \\
\hline 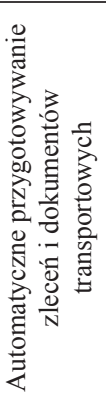 & $\begin{array}{l}\text { Giełdy oferują automatyzację w przygotowa- } \\
\text { niu zleceń na podstawie zgłoszonych wcze- } \\
\text { śniej ofert czy też zapisanych szablonów. } \\
\text { Dotyczy to także przygotowania dokumen- } \\
\text { tów przewozowych. Udostępniane wzory } \\
\text { tworzone są według aktualnych regulacji } \\
\text { prawnych oraz zawierają najpopularniejsze } \\
\text { zapisy typowe dla tych dokumentów. }\end{array}$ & $\begin{array}{l}\text { Szczególnie dla nowych } \\
\text { firm pokusa usprawnie- } \\
\text { nia wystawiania zleceń } \\
\text { transportowych i przy- } \\
\text { gotowania dokumentów } \\
\text { może być atrakcyjna. Pa- } \\
\text { miętać jednak należy, że } \\
\text { szablony obejmują jedy- } \\
\text { nie standardowe zapisy, } \\
\text { które nie zabezpieczają } \\
\text { często przewoźnika przed } \\
\text { wszystkimi zagrożeniami. }\end{array}$ & $\begin{array}{l}\text { Stworzenie i bieżące } \\
\text { aktualizowanie wła- } \\
\text { snych szablonów zle- } \\
\text { ceń według obowią- } \\
\text { zujących przepisów } \\
\text { prawnych. Konsultacja } \\
\text { zastosowanych zapi- } \\
\text { sów z prawnikami. }\end{array}$ \\
\hline
\end{tabular}

Źródło: opracowanie własne na podstawie informacji udzielonej przez pracowników infolinii sprzedażowych poszczególnych usługodawców oraz na podstawie własnego doświadczenia zawodowego. 
Jak wynika z zestawienia w tabeli 2, ryzyko w korzystaniu z giełd transportowych wynika szczególnie:

- ze zbytniego zaufania usługobiorców do jakości dostarczanych przez usługodawcę opcji oraz wiarygodności innych zarejestrowanych kontrahentów,

- z nieskutecznego działania usługodawcy w zakresie weryfikacji usługobiorców i regulacji działania platformy,

- z działania nieuczciwych kontrahentów, którzy mimo ostrożnego działania firm oraz bardzo dobrej kontroli usługodawców zawsze mogą znaleźć sposób na zastosowanie nieuczciwych praktyk,

- z kwestii technicznych takich jak jakość Internetu.

Ryzyko, na które narażone są firmy transportowe korzystające z giełd, nie jest w pełni od nich zależne. Szczególnie niepokojące jest pojawiania się zagrożeń po stronie operatora platformy, którego obowiązkiem powinno być zapewnianie jak najwyższej jakości oferowanych usług, a także bezwzględne karanie łamania przez usługobiorców zasad dobrego biznesu. Warto także podkreślić, że część z zagrożeń, które występują w ramach giełd dotyczy firm transportowych bez względu na to, czy korzystają z tych platform, czy też nie. Korzystając z platform (szczególnie płatnych), przewoźnicy mogą ulec złudnemu poczuciu bezpieczeństwa i zapomnieć o istniejącym ryzyku.

\section{Podsumowanie i wnioski}

1. Na podstawie zebranych informacji potwierdzono, że elektroniczne giełdy transportowe są ważnym narzędziem kształtującym współczesny rynek przewozów drogowych w Europie. Są one pozytywnie oceniane przez większość korzystających z nich firm. Giełdy oferują bardzo rozbudowaną funkcjonalność obejmującą praktycznie wszystkie sfery działania firm transportowych.

2. Udowodniono hipotezę pierwszą, wyraźnie wskazując potencjalne ryzyko płynące z wykorzystania giełd transportowych. Usługodawca choć stara się dbać o wysoki poziom usług nie może zapewnić odbiorcom pełnego bezpieczeństwa, a właśnie tak czuje się wielu z jej użytkowników. Niezbędne jest, aby usługodawcy w sposób bardziej restrykcyjny kontrolowali usługobiorców i karali wszelkie przejawy niepoprawnych działań. Ze strony przewoźników natomiast konieczne jest bardziej świadome korzystanie z usługi.

3. Przeprowadzona analiza literatury przedmiotu pozwoliła na potwierdzenie hipotezy drugiej. Naukowcy i przedsiębiorcy rzadko zwracają uwagę na negatywne strony korzystania $z$ giełd transportowych. Mogą być one bardzo pożytecznym narzędziem w pracy firmy transportowej, ale żeby korzystać z nich we właściwy sposób, należy mieć świadomość ryzyka i zdobyć niezbędne doświadczenie pomagające w stosowaniu oferowanej funkcjonalności. 


\section{Literatura}

Adamska, A., 2009: Ryzyko w działalności przedsiębiorstwa - podstawowe zagadnienia, [w:] Ryzyko w działalności przedsiębiorstw, Oficyna Wydawnicza SGH, Warszawa.

Bartczak A., Barańska A., 2016: Wpływ giełd transportowych na funkcjonowanie przedsiębiorstw z branży logistycznej, Logistyka 1, 163-172.

Bernstein P.L., 1997: Przeciw bogom. Niezwykłe dzieje ryzyka, WIG-Press, Warszawa.

Cyganik J., 2014: Ryzyko w transporcie drogowym - źródła i wielkość szkód, Logistyka 3, 31 $-36$.

Czerwonka K., Cież M., 2008: hasło ryzyko, [w:] Encyklopedia zarządzania, [źródło elektroniczne] https://mfiles.pl/pl/index.php/Ryzyko [dostęp: 27.09.2018].

Dereń M., 2017: Metodyka szacowania ryzyka w Zintegrowanym Systemie Zarządzania, WIML, Warszawa.

Eurostat, 2018: Gross domestic expenditure on R\&D (GERD), [źródło elektroniczne] https:// ec.europa.eu/eurostat $/ \operatorname{tgm} /$ table.do?tab=table \&init $=1 \&$ language $=$ en $\&$ pcode $=\operatorname{ttr} 00005 \&$ plugin=1 [dostęp: 24.09.2018].

GUS, 2018: Transport - Wyniki działalności w 2017 r., Warszawa, Szczecin.

Kisielewski P., Leśniakiewicz M. 2016: Charakterystyka i analiza porównawcza europejskich elektronicznych giełd transportowych, Autobusy: technika, eksploatacja, systemy transportowe 17 (6), 1368-1377.

Leończuk D., 2013: Giełdy transportowe oraz platformy przetargowe - elektroniczne narzędzia wspomagające wybór przewoźnika w transporcie samochodowym, Gospodarka Materiałowa i Logistyka 10, 18-26.

Lewandowski P., Dziechciarz M., 2011: Wpływ giełd transportowych na sektor TSL, Logistyka 5, $1125-1141$.

Maj A., 2017: Zarządzanie ryzykiem w przedsiębiorstwie - studium przypadku, Organizacja i Zarządzanie 1 (37), 107-117.

Osypchuk O., 2018: Wykorzystanie giełd transportowych a kształtowanie jakości usług transportowych w drogowych przewozach ładunków, [w:] Innowacje w zarządzaniu i inżynierii produkcji, Oficyna Wydawnicza Polskiego Towarzystwa Zarządzania Produkcją, Opole.

Palczewska A., Barwiński S., Borowiecki Ł., 2012: Znaczenie Giełdy Transportowej dla współczesnych przedsiębiorstw produkcyjnych, transportowych i spedycyjnych na przykładzie giełdy Trans.eu, [w:] Funkcjonowanie e-biznesu. Zasoby, procesy, technologie, Wydawnictwo Uniwersytetu Łódzkiego, Łódź.

Piekarski W., Dudziak A., Rudzińska J., 2015: Zarządzanie ryzykiem w transporcie drogowym, Logistyka 6, 290-295.

Rokicki T., 2016: Ekonomiczno-organizacyjne uwarunkowania towarowego rynku usług transportowych, Wydawnictwo SGGW, Warszawa.

Romanow P., Stajniak M., Konecka S., 2017: Wybrane aspekty zagrożeń i ryzyka w transporcie, Autobusy: technika, eksploatacja, systemy transportowe 18 (12) [CD].

Stokłosa J., 2011: Zarządzanie ryzykiem w łańcuchach transportowych, Zeszyty Naukowe Wydziału Transportu i Informatyki. Transport i Informatyka 1 (1), 87-98.

Szczepankiewicz E.I., 2016: Wykorzystanie punktowej metody oszacowania ryzyka operacyjnego w instytucjach finansowych, Studia Ekonomiczne, Zeszyty Naukowe Uniwersytetu Ekonomicznego w Katowicach 298, 100-114.

Walasek J., Miszczak A., 2013: System zarządzania ryzykiem firmy transportowo-spedycyjnej „ALFA”, Obronność, Zeszyty Naukowe Wydziału Zarządzania i Dowodzenia Akademii Obrony Narodowej 4 (8), 137-162. 
Adres do korespondencji:

dr hab. inż. Tomasz Rokicki

(https://orcid.org/0000-0003-3356-2643)

Szkoła Główna Gospodarstwa Wiejskiego w Warszawie

Wydział Nauk Ekonomicznych

Katedra Logistyki

ul. Nowoursynowska 166, 02-787 Warszawa

tel. $(+48) 225934259$

e-mail: tomaszrokicki@op.pl

Stanisław Bereziński

(https://orcid.org/0000-0003-4971-0137) 


\title{
Ekonomika i Organizacja Logistyki \\ 3 (3), 2018, 79-91
}

DOI: 10.22630/EIOL.2018.3.3.24

\author{
Joanna Stankiewicz ${ }^{1}$, Konrad Michalski ${ }^{2}$ \\ 1 eMag.pl \\ ${ }^{2}$ Szkoła Główna Gospodarstwa Wiejskiego w Warszawie
}

\section{Rozwiązania z zakresu inteligentnych systemów transportowych w wybranych miastach w Polsce \\ Solutions in the field of intelligent transport systems in selected cities in Poland}

\begin{abstract}
Synopsis. W artykule podjęto tematykę inteligentnych systemów transportowych (ITS), które stanowią jedną z możliwych dróg w poszukiwaniu poprawy życia i innowacyjności w funkcjonowaniu miasta. Transport publiczny jest najbardziej rozległym, a zarazem najczęściej użytkowanym elementem systemu logistycznego miasta, poszukiwane są więc różne sposoby na poprawę zarówno jakości (dostępność, bezpieczeństwo, punktualność itd.) funkcjonowania miasta jako jednostki gospodarującej, jak i przestrzeni do życia dla mieszkańców. Beneficjentami podejmowanych działań są więc pasażerowie transportu (mieszkańcy, dojeżdżający do pracy, turyści itd.), ale także instytucje i urzędy realizujące usługi na rzecz społeczeństwa. Celem opracowania jest identyfikacja i charakterystyka rozwiązań z zakresu ITS w publicznej sieci komunikacyjnej w wybranych miastach wojewódzkich w Polsce (Rzeszów, Bydgoszcz, Wrocław). Artykuł ma charakter przeglądowy. Wykorzystano literaturę przedmiotu, zwłaszcza z zakresu logistyki miasta i telematyki, a także informacje i dane pochodzące $\mathrm{z}$ miast wdrażających przedmiotowe rozwiązania.
\end{abstract}

Słowa kluczowe: logistyka miejska, telematyka, inteligentne systemy transportowe, transport publiczny

\begin{abstract}
The article discusses the subject of intelligent transport systems (ITS), which are one of the possible ways in search of improving life and innovation in the city's functioning. Because public transport is the most extensive and the most frequently used part of the city's logistic system, various methods are sought for improving the quality (availability, safety, punctuality, etc.) of the city's functioning as an economic unit as well as living space for its residents. Beneficiaries of the actions taken are therefore passengers of this transport (residents, commuters, tourists, etc.), but also institutions and offices providing services for the benefit of society. The aim of the study is to identify and characterize solutions in the field of ITS in a public communication network in selected voivodship cities in Poland (Rzeszów, Bydgoszcz, Wrocław). The article is of review nature. The literature of
\end{abstract}


the subject, in particular in the field of city logistics and telematics, as well as information and data from cities implementing presented solutions were used.

Key words: city logistics, telematics, intelligent transport systems, public transport

\section{Wstęp}

Telematyka wspiera zarządzanie ruchem towarowym i osobowym poprzez zastosowanie technologii z zakresu telekomunikacji, informatyki, pomiarów, automatyzacji, a także technik monitorowania i zarządzania siecią komunikacyjną. W założeniu zastosowanie rozwiązań z zakresu inteligentnych systemów transportowych (ITS) wpływa pozytywnie na przepustowość dróg, liczbę wypadków, czas i komfort podróży, upraszcza proces przemieszczania się. Te przykładowe rezultaty działań należy traktować jako korzystnie wpływające na jakość życia w mieście, przyjmując perspektywę mieszkańca - pasażera. Implementacja rozwiązań telematycznych pozwala optymalnie gospodarować infrastrukturą i zaspokajać oczekiwania społeczne - to z kolei spojrzenie na jakość z punktu widzenia zarządzających miastem. Ciągły rozwój zmusza do szukania coraz to nowych rozwiązań - to wymóg wobec włodarzy miasta.

W Polsce systemy typu ITS są coraz częściej wdrażane dzięki dofinansowaniu ze środków strukturalnych Unii Europejskiej. Przykładem beneficjenta środków skonsumowanych na rzecz rozwiązań ITS jest np. Lublin [Osiecki 2018]. Mniejsze ośrodki miejskie, np. Jaworzno, także podejmują konkretne działania i stawiają chociażby na wymianę taboru przewozowego, decydując się na elektryczne, proekologiczne pojazdy, w tym wypadku oparte na technologii wymiennych baterii [Warpechowska 2018a].

Wszystkie powyższe działania wpisują się w trend inteligentnego miasta (ang. smart city). Miasto takie wykorzystuje częściowo lub nawet całkowicie autonomiczne (w rozumieniu sprawowania kontroli przez człowieka) technologie IT, oparte na przepływie informacji w czasie rzeczywistym, otwarte (dostępne) także dla ich użytkowników (mieszkańców), mające poprawiać zarówno poziom życia, jak i funkcjonowanie miasta jako jednostki gospodarującej.

\section{Pojęcie logistyki miejskiej}

Podstawową kategorią dla miasta jest przestrzeń (miejsca, środowiska), która ma swój wymiar materialny w postaci budowli, ulic czy systemów zasilania (energetyka, kanalizacja, ciepłownictwo). Elementy komunikacyjne łączą inne elementy miasta będące miejscami pracy, zamieszkania, wypoczynku, załatwiania spraw administracyjnych, tworząc jednolity układ przestrzenny. Komunikacja jest więc czynnikiem organizacyjnym, służącym ludności do pokonywania przestrzeni i wzajemnego porozumiewania się oraz zacieśniania więzi społecznych. Z kolei transport umożliwia realizację przepływów ładunków służących zagwarantowaniu dostaw niezbędnych do zaspokojenia potrzeb użytkowników miast oraz wywozu z nich tych rzeczy, które są już niepotrzebne [Szołtysek 2009]. 
Badacze z zakresu logistyki postrzegają miasto jako obszar, gdzie można stosować rozwiązania z zakresu zarządzania logistycznego. Zasady te, w skrócie, opierają się na realizacji optymalnych przepływów fizycznych pod kątem czasu, kosztów i jakości, tworzących tzw. złoty trójkąt logistyki [Jedliński 1998]. W praktyce „,boki” tworzące złoty trójkąt logistyki przyjmują oczekiwania, aby dane przepływy wykonać szybciej (czas), taniej (koszty) i ,dobrze” zgodnie z oczekiwaniami (jakość).

W mieście należy zidentyfikować konkretne strumienie logistyczne (ludzi, towarów, odpadów, energii, informacji itd.), których przepływy są przedmiotem zarządzania. W jego toku występują konkretne problemy (korki, braki w dostawach, zanieczyszczenia, braki w dostawach prądu, brak rozkładów jazdy na przystankach itd.), dla których należy znaleźć rozwiązania. Minimalizacja tym podobnych problemów pomaga odciążyć miasto od negatywnych skutków oddziaływania jednostek gospodarczych, a w konsekwencji zwiększyć ich konkurencyjność. Co więcej miasta nie są zamkniętymi jednostkami, traktuje się je jak systemy otwarte, a sprzężenia zwrotne i ciążenia strumieni logistycznych z terenów ościennych do miast są niezaprzeczalne. Stosowane w miastach rozwiązania oddziałują nie tylko na ośrodki zurbanizowane, ale nawet na całe regiony [Tundys 2012].

Miasto jest formułą, która charakteryzuje się obszarem o dużej gęstości zasiedlenia, a więc w tym przypadku zarówno natężenie, jak i prawdopodobieństwo wystąpienia określonych problemów, np. związanych z kongestią na drogach, zawsze będą większe niż na terenach o niższym poziomie zaludnieniu. Pewne możliwości daje dziedzina wiedzy znana jako logistyka miejska wraz ze swoimi narzędziami. Logistyka miejska bardzo szybko rozwija się, co wynika z dynamicznego rozwoju miast i ze skutków ich zatłoczenia, ale także z konieczności ciągłego wprowadzania zmian w funkcjonowaniu tych obszarów [Górniak 2016].

Logistyka miejska (według definicji logistyki Council of Logistic Management) obejmuje procesy planowania, realizacji i kontroli przepływów inicjowanych na zewnątrz miasta i skierowanych do niego, inicjowanych w mieście i skierowanych na zewnątrz niego, przechodzących przez miasto i tych wewnętrznych w mieście. Główne obszary badań logistyki miejskiej to [Gołembska 2010].:

- transport towarowy, dostawczy i wywozowy, przewozy tranzytowe,

- zabezpieczenie i składowanie dóbr na rzecz miasta,

- osobowy transport miejski i podmiejski, tranzytowy ruch osobowy,

- zaopatrzenie miasta,

- wywóz odpadów i nieczystości.

\section{Telematyka $\mathbf{j}$ jej zastosowanie $\mathbf{w}$ transporcie}

W ramach telematyki stosuje się następujące systemy [Wydro 2005]:

- komunikacji elektronicznej, łączące elementy systemu telematycznego (sieci rozległe WAN i lokalne LAN, systemy telekomunikacji ruchomej, satelitarne itd.),

- pozyskiwania informacji (czujniki pomiarowe, kamery, radary itp.),

- prezentacji informacji dla administratorów systemu telematycznego (systemy GIS, systemy kontroli dostępu itp.),

- prezentacji informacji dla użytkowników systemu (znaki o zmiennej treści, sygnalizacja świetlna, radiofonia, technologie internetowe: WAP, WWW, SMS itd.) 
Przykładem szerokiego zastosowania rozwiązań telematycznych jest transport. Zakres zastosowań telematyki w transporcie obejmuje systemy, które pozwalają, ze względu na transmisję danych i ich analizę, oddziaływać na zachowanie uczestników ruchu lub funkcjonowanie elementów technicznych w pojazdach, również w czasie ich poruszania się. Rozwój tak rozumianego inteligentnego transportu dąży do zwiększenia bezpieczeństwa i komfortu podróżowania. Zapewnienie bezpieczeństwa na drogach ma na celu zmniejszenie liczby kolizji drogowych, co z kolei niesie za sobą mniejsze koszty społeczne (odszkodowania, świadczenia, leczenie itd.).

Celem stosowania telematyki w logistyce miasta jest też optymalizacja lokalizacji węzłów logistycznych (np. przystanki przesiadkowe dla jednego rodzaju transportu, np. autobusowego lub dworce integrujące więcej niż jedną gałąź transportu w ramach aglomeracji, np. kolej i tramwaj). W szerszym kontekście jednym z celów działań w ramach logistyki miasta jest redukcja niekorzystnego wpływu człowieka na otoczenie poprzez m.in. ograniczanie przejeżdżanych kilometrów, a więc i emisji szkodliwych związków do atmosfery. Kluczową funkcją ITS jest natomiast operowanie informacją dzięki pozyskiwaniu, przekształcaniu i dystrybucji informacji, w tym ich transmisja i wykorzystanie, np. do automatycznego kierowania ruchem. Wszystkie te procesy są niezależne od użytkowników infrastruktury.

Inteligentne systemy transportowe cechują się: integracją technologii, narzędzi i oprogramowania, zapewniającą sprawny przepływ informacji, ,inteligencją", rozumianą jako zdolność do podejmowania decyzji w zmiennych sytuacjach, elastycznością i zdolnością do adaptacji - możliwością tworzenia konfiguracji w zależności od potrzeb, efektywnością rozumianą jako powszechność korzyści ze stosowania [Pałys i Pałys 2008].

Obszary transportu wspierane telematyką obejmują [Szołtysek 2009]:

- sterowanie ruchem pojazdów, w tym ostrzeganie o niebezpiecznych sytuacjach, wpływanie na prędkość jazdy, utrzymywanie przyjętych odstępów między pojazdami, sterowanie sygnalizacją świetlną, kierowanie zmianą kierunków ruchu,

- sterowanie potokami ruchu, unikanie zakłóceń wynikających z przekazywania informacji na danym odcinku, tworzenie objazdów dla odcinków przeciążonych lub zablokowanych,

- pobieranie opłat, gdzie w komunikacji zbiorowej funkcjonują już w pełni zautomatyzowane systemy poboru opłat za przejazd, których działanie polega na automatycznym rejestrowaniu momentu wsiadania i wysiadania pasażerów,

- dane o możliwościach podróży, gdzie podstawę dynamicznej informacji stanowią meldunki o stanie ruchu na drogach, uzyskiwane poprzez automatyczne pomiary, czujniki pod powierzchnią jezdni, zdalna ocenę obrazu z kamer.

\section{Rozwiązania z zakresu ITS w wybranych miastach wojewódzkich w Polsce}

\section{Rzeszów}

Głównym środkiem transportu publicznego w stolicy regionu podkarpackiego były i są nadal autobusy. Władze Rzeszowa zrealizowały w latach 2007-2015 projekt pod nazwą „Budowa systemu integrującego transport publiczny Miasta Rzeszowa i okolic”. 
Koszt projektu wyniósł ponad $333 \mathrm{mln}$ zł i uzyskał ponad $250 \mathrm{mln}$ zł dofinansowania z Unii Europejskiej. Był to projekt zrealizowany w formule ,zaprojektuj i wybuduj”, a jego inwestorem był Urząd Miasta Rzeszów [2012]. Rzeszowski inteligentny system transportowy (RIST), filar całego projektu, był wdrażany w latach 2010-2015, a jego koszt wyniósł ponad $16 \mathrm{mln}$ zł, z czego $14 \mathrm{mln}$ pochodziło z programu operacyjnego „Infrastruktura i Środowisko”. Cele szczegółowe wdrożenia ITS były następujące [Inteligentne systemy transportowe projekt Rzeszów, b.d.]:

- poprawa funkcjonalności systemu transportu publicznego poprzez system dynamicznej informacji pasażerskiej,

- uruchomienie monitoringu ruchu ciężarowego i udziału pojazdów przeciążonych,

- poprawa bezpieczeństwa dróg i ulic Rzeszowa,

- poprawa dostępności zarządzania ruchem.

W skład RIST wchodzą: system obszarowego sterowania ruchem drogowym (SOSRD), system zarządzania transportem publicznym (SZTP), system informacji pasażerskiej (e-Info), system elektronicznego poboru opłat (e-Bilet).

System obszarowego sterowania ruchem drogowym jest centralnym elementem RIST i ma kluczowy wpływ na proces usprawniania funkcjonowania komunikacji zbiorowej $\mathrm{i}$ indywidualnej w Rzeszowie. System wspomaga zarządzanie ruchem na obszarze miasta $\mathrm{z}$ zastosowaniem m.in. priorytetyzowania komunikacji zbiorowej, do czego służy dynamiczna optymalizacja sterowania ruchem, obejmująca skrzyżowania, informująca użytkowników o utrudnieniach, natężeniu ruchu i sytuacji meteorologicznej za pomocą 17 tablic o zmiennej treści [Urząd Miasta Rzeszów 2012]. Operatorzy centrum obszarowego sterowania ruchem - COSR (jedno ze stanowisk znajduje się na rys. 1) dbają o to, aby w mieście występowało jak najmniej korków, a kierowcom dostarczana była precyzyjna informacja o sytuacji na drodze.

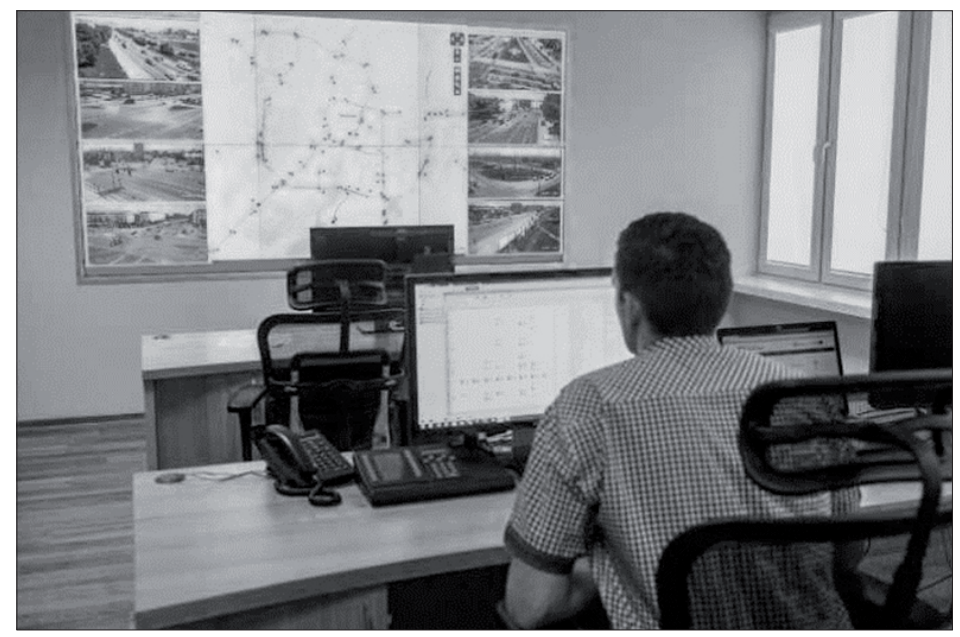

Rysunek 1. Stanowisko dyspozytora ruchu w Rzeszowie

Figure 1. Traffic dispatcher station in Rzeszów

Źródło: Rzeszów News [2016]. 
Kluczowym elementem SOSRD jest podsystem sterowania sygnalizacją świetlną na 53 skrzyżowaniach. Głównym celem funkcjonowania podsystemu jest uzyskanie maksymalnych przepustowości w kluczowych węzłach komunikacyjnych. System ma również na celu „rozprowadzenie” ruchu w mieście na poszczególne ulice, czyli tak, aby nie powstawały zatory. System dba również o kierowanie pojazdów na trasy alternatywne.

Podstawą działania systemu sterowania sygnalizacją świetlną są wiązki koordynacyjne, czyli zatopione w asfalcie pętle indukcyjne, które wyczuwają ruch pojazdów na ulicy i dzięki temu system może dostosować sygnalizację do natężenia ruchu. Informacje uzyskiwane w ramach odczytów przesyłane są do COSR i tam przetwarzane przez aplikację, która automatycznie dostosowuje sygnalizację do potrzeb. Dzięki temu sygnalizacja działa racjonalnie i dostosowuje swoją częstotliwość do pory dnia i nocy. W skład SOSRD w wchodzi też 70 kamer CCTV (ang. closed-circuit television), z których obraz trafia do centrum. Trzecim elementem SOSRD są stacje meteo, mierzące i przekazujące informacje o stanie warunków meteorologicznych na drogach, zarówno podróżującym na własną rękę, komunikacją zbiorową, jak i pieszym. Urządzenia pomiarowe mierzą temperaturę powietrza i nawierzchni, wilgotność, ciśnienie powietrza i siłę wiatru. Dane z urządzeń pomiarowych są wysyłane, przetwarzane i analizowane przez operatorów centrum sterowania $\mathrm{z}$ wykorzystaniem aplikacji, która generuje komunikat wyświetlany na tablicach świetlnych.

Nadawanie priorytetów komunikacji zbiorowej i pojazdom uprzywilejowanych (służby medyczne, mundurowe itd.) w Rzeszowie polega na przekazywaniu informacji ze sterownika zamontowanego w pojeździe do sterownika sygnalizacji świetlnej, który sprawdza możliwość przejazdu bez konieczności zatrzymania się. Aby tak się stało, analiza ruchu pojazdu musi wykazać, że pojazd będzie mógł przejechać w trakcie danej fazy sygnalizacji świetlnej. Jeżeli takie rozwiązanie nie jest możliwe, system generuje inne: wydłużenie, do dopuszczalnego maksimum, fazy pozwalającej na przejazd pojazdowi, zmianę bieżącej fazy do dopuszczalnego minimum i uruchomienie fazy pozwalającej na przejazd lub przyspieszenie fazy zezwalającej na przejazd poprzez skrócenie faz poprzedzających do dopuszczonego minimum. Rozwiązanie to jest oparte na tzw. priorytecie centralnym [Okoń 2012].

Kolejnym elementem ITS jest SZTP. Głównym celem tego podsystemu jest identyfikacja lokalizacji pojazdów, zliczanie liczby pasażerów i kontrola jakości usług komunikacji zbiorowej, co pozwala na szybkie reagowanie na aktualne potrzeby, np. w zakresie rozkładu jazdy, przebudowy układu drogowego, weryfikacji algorytmów sterowania. Każdy autobus miejski wyposażony jest w nadajnik GPS, kamery, czujniki, detektory, komputer pokładowy, sterowniki i system łączności. To pozwala generować informacje o położeniu i prędkości jazdy autobusu, a dane wyświetlane są w COSR na ekranie z mapą miasta. System wyświetla punktualność w stosunku do jazdy, zrealizowany czas przejazdu i numer autobusu. Operatorzy COSR mogą na bieżąco łączyć się z kierowcami i dowiedzieć się o powodach odchyleń w zaplanowanych kursach, a w razie stwierdzonego na trasie zatoru mogą proponować objazdy. W przypadku braku możliwości dojazdu autobusu na przystanek, stosowna informacja jest wyświetlana na tablicy.

W Rzeszowie działa też system ważenia pojazdów, który kontroluje nacisk osi pojazdu na drogę za pomocą czujników zatopionych pod asfaltem. Cały pomiar trwa w czasie 
jazdy, bez potrzeby zatrzymania się. Dane z pomiarów są wyświetlane natychmiast na tablicy widocznej dla kierowcy. Głównym celem tego rozwiązania jest zachęcenie kierowców do zmiany trasy, gdyż przeładowane ciężarówki niszczą drogi [Gubernat 2018].

\section{Bydgoszcz}

W stolicy województwa kujawsko-pomorskiego działa centrum zarządzania ruchem i transportem (CZRiT), w ramach bydgoskiego inteligentnego systemu transportowego (BIST) [ZDMiKP Bydgoszcz 2015b]. Centrum zarządzania ruchem i transportem także korzysta z tablic o zmieniającej się treści (rys. 2).

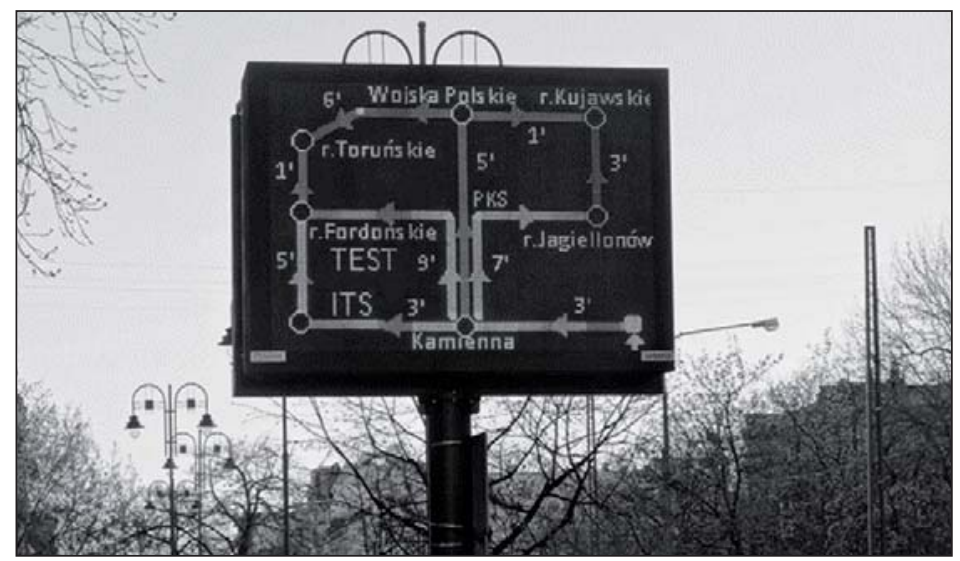

Rysunek 2. Tablica zmiennej treści w Bydgoszczy

Figure 2. Table of variable content in Bydgoszcz

Źródło: [Inteligentne systemy transportowe projekt Bydgoszcz, b.d].

Tablice służą dyspozytorom do przekazywania kierowcom informacji dotyczących dojazdu w konkretne miejsce, na przykład do centrum. Tablice wyświetlają też informacje o objeździe, a także czas dojazdu do wybranego celu. Wszystkie informacje przedstawiane są w czasie rzeczywistym i generowane są przez operatorów mających bieżący wgląd do widoku z kamer. Mieszkańcy mają także możliwość podglądu widoku z kamery, udostępnianego na dedykowanej stronie internetowej.

Każdy tramwaj w Bydgoszczy jest wyposażony w nadajnik radiowy krótkiego zasięgu, który współpracuje z komputerem pokładowym generującym sygnał wywołujący priorytet przejazdu przed dojazdem do skrzyżowania. Istotą priorytetu lokalnego (rys. 3) jest więc przekazywanie informacji bezpośrednio z pojazdu do sterownika bez pośrednictwa systemu sterowania ruchem i jest stosowany na mało lub średnio obciążonych sygnalizacjach, gdzie nie występuje konieczność współdziałania z centralnym systemem sterowania ruchem. Czynnikiem sukcesu jest tutaj dokładna detekcja pojazdu, gdyż nieprecyzyjnie działający nadajnik może spowodować brak priorytetu w odpowiednim momencie lub aktywowanie go bez potrzeby. Aby zminimalizować to ryzyko, zainstalowano zestawy automatyki zwrotnic tam, gdzie motorniczy dotąd przełączał je ręcznie [ZDMiKP Bydgoszcz 2015b]. 


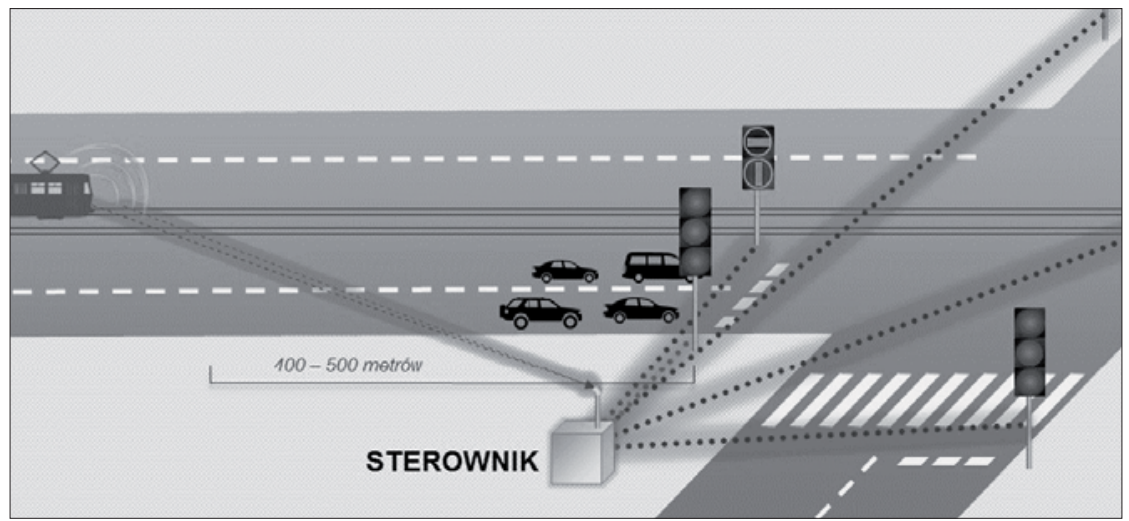

Rysunek 3. Działanie mechanizmu priorytetu lokalnego w Bydgoszczy

Figure 3. The local mechanism's functioning in Bydgoszcz

Źródło: [ZDMiKP Bydgoszcz 2015b].

\section{Wroclaw}

Rozwiązania z zakresu ITS są założenia dynamiczne i interaktywne, a informacja jest udostępniana uczestnikom ruchu. Każdy z ITS np. we Wrocławiu ma swój portal (rys. 4).

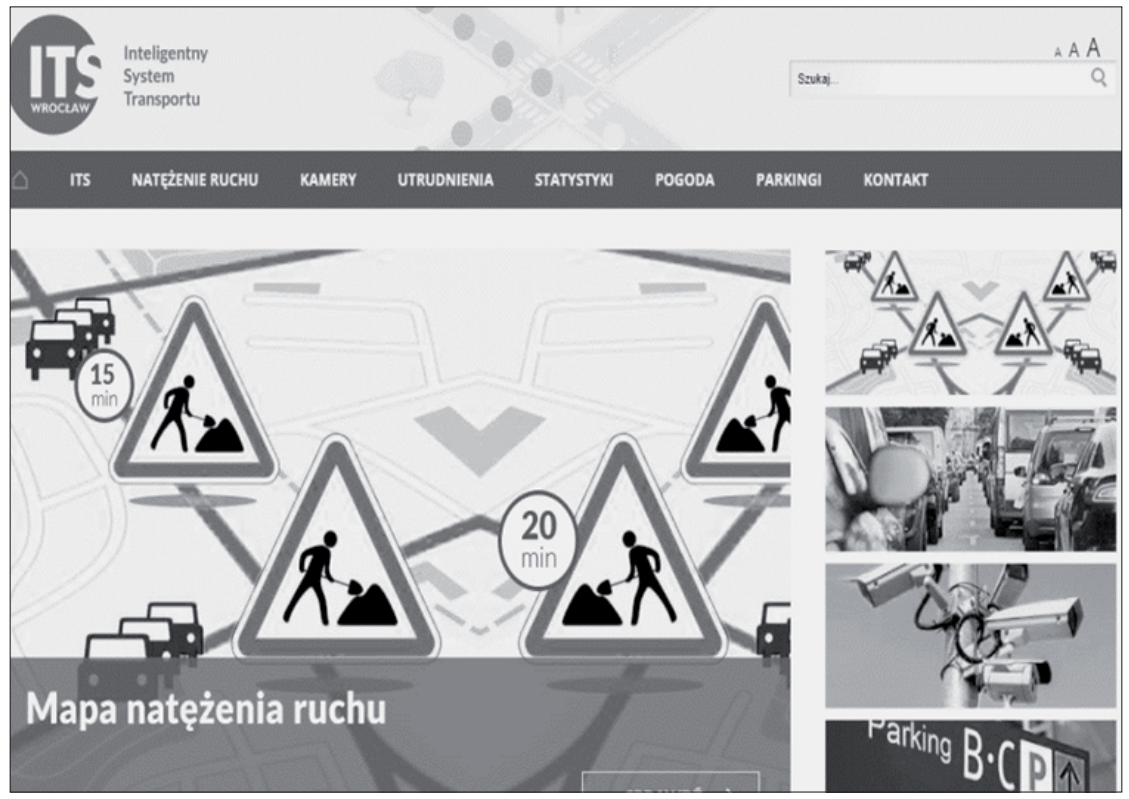

Rysunek 4. Interfejs portalu internetowego ITS we Wrocławiu

Figure 4. Interface of the ITS internet portal in Wrocław

Źródło: [Inteligentne systemy transportowe projekt Wrocław, b.d.]. 
Portal ITS pełni funkcję repozytorium wiedzy dla pasażera, ale też kiosku informacyjnego, tablicy o zmiennej treści, parkingowej itd., czyli wszystkich kluczowych elementów systemu. ITS we Wrocławiu udostępnia także informacje parkingowe, generowane na podstawie danych dostarczanych na bieżąco przez operatorów parkingów. Do elementów podsystemu należą też wyświetlacze (rys. 5), których zadaniem jest informowanie kierowców o ilości wolnych miejsc na parkingach w najbliższych strefach płatnego parkowania.

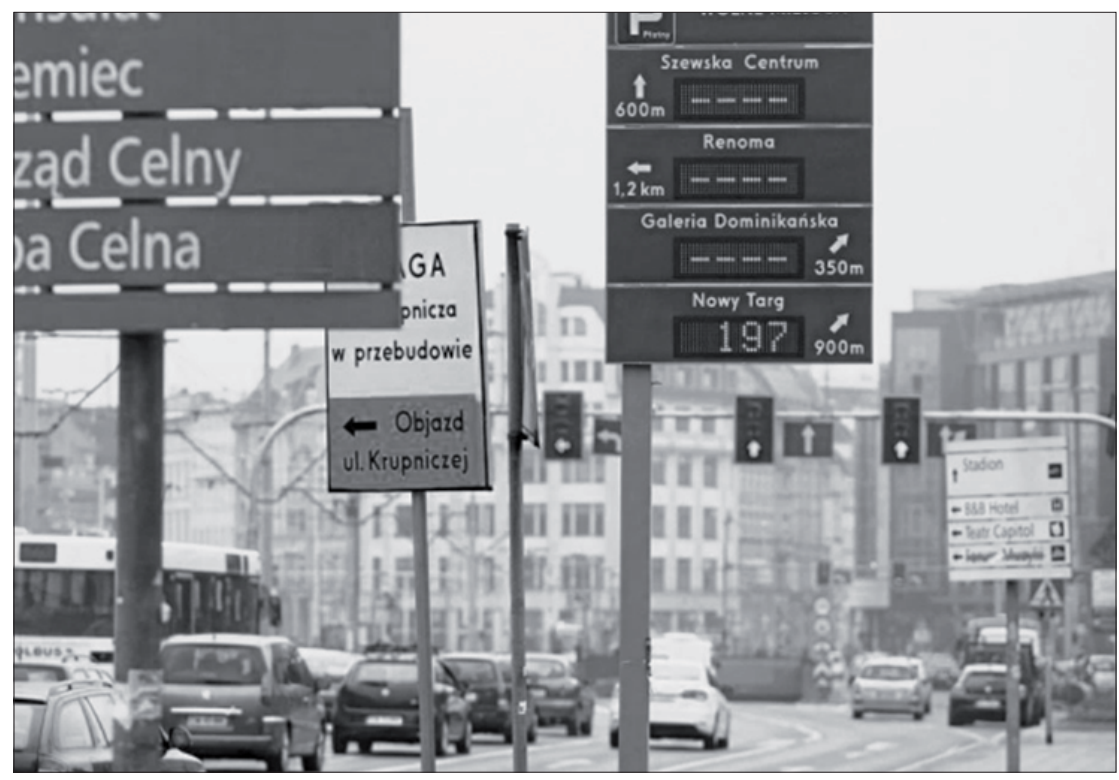

Rysunek 5. Tablica informacji parkingowej we Wrocławiu Figure 5. Parking information board in Wrocław

Źródło: [Skupin 2014].

Ważną funkcjonalnością każdego ITS jest jego analityka. Niezwykle istotnym elementem ITS jest więc repozytorium danych pochodzących z poszczególnych elementów całego systemu, tak aby tę informację móc szybko i skutecznie przetwarzać, analizować i prezentować. Przykładowo, wrocławski ITS posiada repozytoria: bieżących danych lokalizacyjnych i rozkładowych, wyłączeń z ruchu, bieżących zgłoszeń i danych pomiarowych, danych wizyjnych, a także bazy: GIS, referencyjną i pojazdów. Przechowywane w repozytorium zasoby są podstawą do tworzenia raportów, analiz i komunikatów. Na bazie repozytorium zbudowane są systemy analityczne i raportowe. Operatorzy CZiSR tworzą raporty, które są elementem kompleksowego informowania kierownictwa o efektywności zarządzania ruchem i transportem publicznym oraz jakości obsługi pasażera w stolicy Dolnego Śląska. Na podstawie raportów, analitycy nieustannie dążą do poprawy działania systemu, jego optymalizacji oraz do poprawy jakości usług oferowanych przez przewoźników komunikacji miejskiej ${ }^{1}$.

\footnotetext{
${ }^{1}$ Oficjalny portal internetowy Wrocławia, www.wroclaw.pl [dostęp: 25.10.2018].
} 


\section{Cele i korzyści ze stosowania rozwiązań z zakresu ITS w miastach}

Głównymi problemami, z którymi borykała się (do czasu opisanych w artykule zmian) komunikacja publiczna w Rzeszowie, były:

- konieczność przesiadania się z systemu transportu publicznego na indywidualny,

- słaby stan techniczny taboru,

- słaba separacja komunikacji zbiorowej od ruchu samochodowego w mieście,

- spadająca efektywność ekonomiczna transportu publicznego,

- duże straty czasu pasażerów komunikacji miejskiej.

Wyzwaniami w kwestii zarządzania ruchem w Rzeszowie były natomiast ograniczone możliwości oddziaływania na rozkład ruchu w mieście, co sprzyjało kongestii. Kluczem był brak dynamicznej informacji o ruchu i jego natężeniu. System drogowy borykał się $\mathrm{z}$ brakiem rozwiązań w zakresie infrastruktury preferującej transport zbiorowy. Problemem był też brak systemowej regulacji systemu opłat za parking. Efektem tych wszystkich problemów był negatywny wpływ systemu transportowego Rzeszowa na atrakcyjność miasta i jego potencjał rozwojowy. Wdrożone w ramach RIST rozwiązania wpłynęły pozytywnie na punktualność oraz bezpieczeństwo funkcjonowania komunikacji miejskiej w Rzeszowie, a także na bezpieczeństwo na drogach. Wprowadzenie rozwiązań miało również wpływ na poprawę komfortu podróżnych korzystających z komunikacji publicznej [Magdoń 2016].

Wprowadzając w Bydgoszczy rozwiązania w ramach ITS, jako jeden z celów przyjęto poprawę czasu przejazdu transportem indywidualnym na poziomie $6 \%$. Po wprowadzeniu systemu osiągnięto średni wynik poprawy na poziomie $32 \%$, co przerosło wyraźnie oczekiwania $^{2}$. Tabela 1 prezentuje różnice w czasie przejazdu transportem publicznym na wybranym odcinku trasy w Bydgoszczy, a tabeli 2 zmiany w punktualności kursowania jednej z linii w tym mieście.

Tabela 1. Średni czas przejazdu transportem publicznym w Bydgoszczy na wybranej trasie przed wprowadzeniem i po wprowadzeniu ITS

Table 1. The average travel time in public transport in Bydgoszcz on the selected route before and after the implementation of ITS

\begin{tabular}{|l|c|c|c|}
\hline Korytarz & $\begin{array}{c}\text { Średni czas przejazdu } \\
\text { w kwietniu 2014 } \\
{[\mathrm{min}]}\end{array}$ & $\begin{array}{c}\text { Średni czas przejazdu } \\
\text { w marcu 2015 } \\
{[\mathrm{min}]}\end{array}$ & $\begin{array}{c}\text { Oszczędność czasu } \\
\text { [min] }\end{array}$ \\
\hline Wyścigowa-Garbary & $18: 22$ & $16: 45$ & $1: 37$ \\
\hline Garbary-Wyścigowa & $19: 50$ & $18: 00$ & $1: 50$ \\
\hline
\end{tabular}

Źródło: [ZDMiKP Bydgoszcz 2015a].

Głównym celem projektu ITS we Wrocławiu był wzrost skuteczności i efektywności działania systemu transportowego. Usprawnienie ruchu samochodów i pojazdów transportu publicznego oraz wzrost bezpieczeństwa ruchu drogowego były celami szczegółowymi [BIP UM Wrocław 2016]. Po wprowadzeniu ITS czas, jaki był potrzebny na przejazd przez miasto, zredukowano średnio o 18\%, a średni czas jazdy tramwajem skrócił się o 2 min w porównaniu z 2013 rokiem [Komisja Europejska 2016].

\footnotetext{
${ }^{2}$ Zarząd Dróg Miejskich i Komunikacji Publicznej w Bydgoszczy, www.zdmikp.bydgoszcz.pl [dostęp: 25.10.2018].
} 
Tabela 2. Punktualność wybranej linii transportu publicznego (linia 79) w Bydgoszczy przed wprowadzeniem i po wprowadzeniu ITS

Table 2. Punctuality of the selected public transport line (Line 79) in Bydgoszcz before and after the implemention of ITS

\begin{tabular}{|l|c|c|}
\hline Wyszczególnienie & 2014 & 2015 \\
\hline Odsetek kursów punktualnych (\%) & 80,00 & 89,56 \\
\hline Odsetek kursów niepunktualnych (\%) & 20,00 & 10,44 \\
\hline Odsetek przyspieszeń (\%) & 0,57 & 1,12 \\
\hline Odsetek opóźnień (\%) & 19,43 & 9,32 \\
\hline
\end{tabular}

Źródło: [ZDMiKP Bydgoszcz 2015a].

\section{Podsumowanie i wnioski}

Wzrasta świadomość społecznej roli logistyki [Szołtysek i in. 2016, Szołtysek 2018], zwłaszcza w kontekście idei zrównoważonego rozwoju, łączącej cele społeczne, gospodarcze i środowiskowe. Zatłoczone miasto, zwłaszcza w „normalnych” warunkach jego funkcjonowania, a takim jest np. podróż do lub z pracy, jest uciążliwe. Zmęczeni użytkownicy transportu oraz pozostali mieszkańcy miasta mają poczucie niskiej jakości życia. Należy podkreślić, że prognozuje się, że do 2050 roku liczebność miejskiej metropolitarnej populacji wzrośnie do 66\% (w 1950 r. wynosiła ona 30\%, w 2018 r. 55\%). Co ósmy mieszkaniec globu funkcjonuje w jednym z 28 megamiast z minimum $10 \mathrm{mln}$ mieszkańców [Warpachowska 2018b].

Zaakcentowane w artykule rozwiązania z zakresu ITS wzmacniają nie tylko szeroko rozumianą efektywność funkcjonowania miasta, czy szerzej regionu, ale przyczyniają się do wzrostu dobrobytu społecznego, gdzie wysoka jakość życia, determinowana jest także komfortem, łatwością i bezpieczeństwem poruszania się w przestrzeni miejskiej. W polskich warunkach, kompleksowe projekty, oparte na kooperacji miast z podmiotami technologicznymi i partycypacji publiczno-prawnej, są coraz częstsze, co w odniesieniu do obszarów o walorach turystycznych, wypoczynkowych, czy uzdrowiskowych ma też uzasadnienie biznesowe. Lepsza jakość obsługi realizowanej przez miasto, np. w dostępie do rowerów, pojazdów elektrycznych, stacji ładowania samochodów, dostępności parkingów, ale także monitoringu jakości powietrza itd., wpływa na wzrost dochodów miasta, gdyż jego użytkownicy są bardziej skłonni wydatkować swoje środki [Kazimierz Dolny... 2018].

Z całą pewnością kompleksowe rozwiązania miejskie, wykorzystujące ITS są trudniejsze do wdrożenia na większych obszarach, jakimi są metropolie, co powinno być przedmiotem kolejnego przeglądu. Interesujące dla badaczy z obszaru nauk o zarządzaniu powinny być bardziej ogólne problemy badawcze:

- według jakich założeń (paradygmatów) tworzyć skuteczne i efektywne (pod względem ekonomiczności działania) struktury organizacyjne wspierające zarządzanie logistyczne przepływami fizycznymi, w których przełomowe technologie i szczegółowe rozwiązania informatyczne wyznaczają ramy i standardy działania, 
- jako rolę ma do odegrania człowiek (pracownik) w rzeczywistości biznesowej, który obrazowo można zdefiniować jako everything is smart; czy ta rola ma mieć charakter tylko nadzorczy, koordynujący, monitorujący, inny?

\section{Literatura}

Biuletyn Informacji Publicznej Urzędu Miejskiego Wrocławia, 2016: Inteligentny System Transportu „ITS Wrocław”, [źródło elektroniczne] http://bip.um.wroc.pl/artykul/340/20698/ inteligentny-system-transportu-its-wroclaw [dostęp: 01.05.2018].

Gołembska E., 2010: Kompendium wiedzy o logistyce, PWE, Warszawa.

Górniak J., 2016: Znaczenie logistyki miejskiej w wybranych miastach europejskich. Analiza porównawcza, Zeszyty Naukowe Politechniki Częstochowskiej Zarządzanie 24 (1), 140-151, [źródło elektroniczne] http://www.zim.pcz.pl/znwz/files/Znaczenie-logistyki-miejskiej-w-wybranych-miastach-europejskich.-Analiza-porownawcza-.pdf [dostęp: 03.08.2018].

Gubernat B., 2018: Kiedy wagi będą eliminować z ruchu w Rzeszowie przeciążone auta?, [źródło elektroniczne] http://www.nowiny24.pl/motofakty/a/kiedy-wagi-beda-eliminowac-z-ruchu-w-rzeszowie-przeciazone-auta,13063744/ [dostęp: 24.04.2018].

Inteligentne systemy transportowe projekt Bydgoszcz [b.d.], [źródło elektroniczne] http://www. its-frame.pl/its-bydgoszcz.html [dostęp: 03.08.2018].

Inteligentne systemy transportowe projekt Rzeszów [b.d.], [źródło elektroniczne] http://www.itsframe.pl/its-rzeszow.html [dostęp: 03.08.2018].

Inteligentne systemy transportowe projekt Wrocław [b.d.], [źródło elektroniczne] http://its.wroc.pl [dostęp: 08.05.2018].

Jedliński M., 1998: Zarządzanie systemami logistycznymi, Wydawnictwo Naukowe Uniwersytetu Szczecińskiego, Szczecin.

Kazimierz Dolny: pierwsze polskie smart city, Puls Biznesu z 13.06.2018, [źródło elektroniczne] https://www.pb.pl/kazimierz-dolny-pierwsze-polskie-smart-city-931894 [dostęp: 04.08.2018].

Komisja Europejska, 2016: Inteligentny system transportu we Wrocławiu i jego korzystne skutki dla miasta, [źródło elektroniczne] http://ec.europa.eu/regional_policy/pl/projects/poland/ intelligent-transport-tools-give-wroclaw-a-new-lease-of-life [dostęp: 01.05.2018].

Krzeszowski J., 2013: Nieznany Wrocław - centrum sterowania miastem, [źródło elektroniczne] https://www.wroclaw.pl/its-wroclaw-co-to-jest [dostęp: 03.08.2018].

Magdoń P., 2016: RIST - Rzeszowski Inteligentny System Transportowy po wdrożeniu, [w:], Kongres Drogowy, Rzeszów, [źródło elektroniczne] http://kongresdrogowy.pl/files/upload/ PFD_10_RIST_Rzeszowski_ITS_PMagdon.pdf [dostęp: 04.08.2018].

Okoń T., 2012: Priorytety dla transportu publicznego - lokalnie czy centralnie?, ITS Przegląd, [źródło elektroniczne] http://przeglad-its.pl/2012/06/26/priorytety-dla-transportu-publicznego-\%E2\%80\%93-lokalnie-czy-centralnie/ [dostęp: 03.08.2018].

Osiecki A., 2018: Coraz łatwiej jeździć na wschodzie kraju, Rzeczpospolita z 23.11, A27.

Pałys M., Pałys M., 2008: Telematyczne systemy do monitorowania środowiska drogowego w strukturze ITS/Win, Środowisko 2, 223-230, [źródło elektroniczne] http://suw.biblos. pk.edu.pl/resourceDetailsRPK\&rId=1307\&rsAt=20 [dostęp: 03.08.2018].

Rzeszow News, 2016: Urzędnicy zdali test ze znajomości rzeszowskich ulic, [źródło elektroniczne] http://rzeszow-news.pl/urzednicy-zdali-test-na-znajomosci-rzeszowskich-ulic/ [dostęp: 22.02.2017]. 
Rzeszowskiego Transportu Miejskiego e-info [b.d.], [źródło elektroniczne] http://einfo.erzeszow. pl [dostęp: 28.02.2018].

Skupin W., 2014: Wrocław: Postawili efektowne tablice parkingowe, które... świecą pustkami, [źródło elektroniczne] http://www.gazetawroclawska.pl/artykul/3572423,wroclawpostawili-efektowne-tablice-parkingowe-ktore-swieca-pustkami,id,t.html [dostęp: 01.05.2018].

Szołtysek J., 2009: Podstawy logistyki miejskiej, Wydawnictwo Akademii Ekonomicznej w Katowicach, Katowice.

Szołtysek J., 2018: Ewolucja zainteresowań logistyki miasta - nowe kierunki eksploracji naukowobadawczej, Logistyka 1, 11-15.

Szołtysek J., Sadowski A., Kalisiak-Mądelska M., 2016: Logistyka społeczna. Teoria i zastosowanie, Wydawnictwo Uniwersytetu Łódzkiego, Łódź.

Tundys B., 2012: Wpływ rozwiązań logistycznych z zakresu logistyki miejskiej na kształtowanie rozwoju regionów, Zeszyty Naukowe Politechniki Śląskiej. Transport 75, 93-102.

Urząd Miasta Rzeszów, 2012: O projekcie, [źródło elektroniczne] http://www.transport.erzeszow. pl/o-projekcie/opis-projektu [dostęp: 01.03.2018].

Warpechowska B., 2018a: Bezemisyjny transport publiczny w Jaworznie, Puls Biznesu z 22.11, [źródło elektroniczne] https://www.pb.pl/bezemisyjny-transport-publiczny-w-jaworznie946372 [dostęp: 04.08.2018].

Warpechowska B., 2018b: W drodze do inteligentnego miasta, Puls Biznesu z 07.06, [źródło elektroniczne] https://www.pb.pl/w-drodze-do-inteligentnego-miasta-931544 [dostęp: 04.08.2018].

Wydro K., 2005: Telematyka - znaczenie i definicje terminu, Telekomunikacja i Techniki Informacyjne 1-2, [źródło elektroniczne] https:/www.itl.waw.pl/czasopisma/TiTI/2005/1-2/116. pdf [dostęp: 03.08.2018].

Zarząd Dróg Miejskich i Komunikacji Publicznej w Bydgoszczy, 2015: ITS - to już się opłaca, [źródło elektroniczne] http://www.zdmikp.bydgoszcz.pl/index.php/pl/inwestycje-i-projekty/2478-its-to-juz-sie-oplaca [dostęp: 08.05.2018].

Zarząd Dróg Miejskich i Komunikacji Publicznej w Bydgoszczy, 2015: O bydgoskim Systemie ITS, [źródło elektroniczne] http://www.zdmikp.bydgoszcz.pl/index.php/pl/inwestycje-iprojekty/2305-o-systemie-its [dostęp: 03.08.2018].

Adres do korespondencji:

mgr Joanna Stankiewicz

eMag.pl

e-mail: joannastankiewicz1994@gmail.com

dr Konrad Michalski

(https://orcid.org/0000-0001-6997-352X)

Szkoła Główna Gospodarstwa Wiejskiego w Warszawie

Wydział Nauk Ekonomicznych

Katedra Logistyki

ul. Nowoursynowska 166, 02-787 Warszawa

tel.: (+48) 225935603

e-mail: konrad_michalski@sggw.pl 
